\title{
Long-term measurements (2010-2014) of carbonaceous aerosol and carbon monoxide at the Zotino Tall Tower Observatory (ZOTTO) in central Siberia
}

\author{
Eugene F. Mikhailov ${ }^{1,2}$, Svetlana Mironova ${ }^{2}$, Gregory Mironov ${ }^{2}$, Sergey Vlasenko $^{2}$, Alexey Panov $^{3}$, Xuguang Chi $^{4}$, \\ David Walter ${ }^{1}$, Samara Carbone ${ }^{5}$, Paulo Artaxo ${ }^{5}$, Martin Heimann ${ }^{6}$, Jost Lavric ${ }^{6}$, Ulrich Pöschl ${ }^{1}$, and \\ Meinrat O. Andreae ${ }^{1,7}$ \\ ${ }^{1}$ Multiphase Chemistry and Biogeochemistry Departments, Max Planck Institute for Chemistry, \\ P.O. Box 3060, 55020 Mainz, Germany \\ ${ }^{2}$ Department of Atmospheric Physics, Saint-Petersburg University, St. Petersburg State University, \\ SPbSU, SPbU, 7/9 Universitetskaya nab., 199034, St. Petersburg, Russia \\ ${ }^{3}$ Sukachev Institute of Forest, Siberian Branch, Russian Academy of Sciences, 50 Akademgorodok, \\ 660036, Krasnoyarsk, Russia \\ ${ }^{4}$ School of Atmospheric Sciences, Nanjing University, 210023, Jiangsu, China \\ ${ }^{5}$ Instituto de Física, Universidade de São Paulo (USP), Rua do Matão, Travessa R, 187, \\ CEP 05508-900, São Paulo, SP, Brasil \\ ${ }^{6}$ Max-Planck-Institute for Biogeochemistry, Hans-Knöll-Str. 10, 07745 Jena, Germany \\ ${ }^{7}$ Scripps Institution of Oceanography, University of California San Diego, La Jolla, CA 92093, USA \\ Correspondence to: Eugene F. Mikhailov (eugene.mikhailov@spbu.ru)
}

Received: 2 May 2017 - Discussion started: 5 May 2017

Revised: 9 October 2017 - Accepted: 20 October 2017 - Published: 4 December 2017

\begin{abstract}
We present long-term (5-year) measurements of particulate matter with an upper diameter limit of $\sim 10 \mu \mathrm{m}$ $\left(\mathrm{PM}_{10}\right)$, elemental carbon (EC), organic carbon (OC), and water-soluble organic carbon (WSOC) in aerosol filter samples collected at the Zotino Tall Tower Observatory in the middle-taiga subzone (Siberia). The data are complemented with carbon monoxide (CO) measurements. Air mass back trajectory analysis and satellite image analysis were used to characterise potential source regions and the transport pathway of haze plumes. Polluted and background periods were selected using a non-parametric statistical approach and analysed separately. In addition, near-pristine air masses were selected based on their EC concentrations being below the detection limit of our thermal-optical instrument. Over the entire sampling campaign, 75 and $48 \%$ of air masses in winter and in summer, respectively, and $42 \%$ in spring and fall are classified as polluted. The observed background concentrations of $\mathrm{CO}$ and EC showed a sine-like behaviour with a period of $365 \pm 4$ days, mostly due to different degrees of dilution and the removal of polluted air masses arriving at
\end{abstract}

the Zotino Tall Tower Observatory (ZOTTO) from remote sources. Our analysis of the near-pristine conditions shows that the longest periods with clean air masses were observed in summer, with a frequency of $17 \%$, while in wintertime only $1 \%$ can be classified as a clean. Against a background of low concentrations of $\mathrm{CO}, \mathrm{EC}$, and $\mathrm{OC}$ in the near-pristine summertime, it was possible to identify pollution plumes that most likely came from crude-oil production sites located in the oil-rich regions of Western Siberia. Overall, our analysis indicates that most of the time the Siberian region is impacted by atmospheric pollution arising from biomass burning and anthropogenic emissions. A relatively clean atmosphere can be observed mainly in summer, when polluted species are removed by precipitation and the aerosol burden returns to near-pristine conditions. 


\section{Introduction}

The Siberian forests cover about $70 \%$ of the total area of the Eurasian boreal forest and are an important factor controlling global and regional climate. In turn, climate change causes a response of Siberian ecosystems, which shows up in a redistribution of matter and energy between terrestrial ecosystems and the atmosphere (Goetz et al., 2007; Lappalainen et al., 2016). The atmospheric aerosol over Siberia is of particular interest for several reasons. Firstly, biogenic emissions of volatile organic compounds (VOCs) from the vast boreal taiga forest are thought to lead to the formation of secondary organic aerosol (SOA) (Tunved et al., 2006). Secondly, Siberia has been documented to be an important source region of biomass burning aerosol particles that are distributed around the globe in the free troposphere (Conard and Ivanova, 1997; Müller et al., 2005; Warneke et al., 2009). Thirdly, Siberia is one of the few possible background regions in the Northern Hemisphere where near-pristine conditions prevail for certain periods of the year (Chi et al., 2013). Such atmospheric observations in remote areas are very important for providing a reference for evaluating anthropogenic impacts in this and other regions (Andreae, 2007; Carslaw et al., 2013; Spracklen and Rap, 2013).

Despite the relatively remote location and low population density, human impacts on Siberian ecosystems are increasingly noticeable. This includes the expansion of agriculture at the southern end of the boreal forest zone, forest logging, as well as impacts on steppe and forest fire regimes (Chi et al., 2013; Vasileva et al., 2011; Heintzenberg et al., 2013; Mikhailov et al., 2015a; Panov et al., 2015). In addition, the massive expansion of oil and gas wells, predominantly in northwestern Siberia, is likely to have an impact on aerosol and trace gas emissions through gas flaring and potential leaks in the mining and transport infrastructure (Stohl et al., 2013; Heimann et al., 2014).

Typically, two classes of carbonaceous aerosol are commonly present in ambient air - elemental carbon (EC) (often referred to as black carbon or soot; Andreae and Gelencsér, 2006) and organic carbon (OC). Carbon-containing components (EC and OC) account for 10 to $70 \%$ of atmospheric PM mass (Turpin et al., 2000; Zhang et al., 2007). Both OC and EC are important agents in the climate system, which affect the optical characteristics and thermal balance of the atmosphere both directly, by absorbing and scattering incoming solar radiation, and indirectly, by modifying cloud properties (Haywood and Boucher, 2000; Andreae and Merlet; 2001; Pierce et al., 2007; Bond et al., 2013; Andreae and Ramanathan, 2013; Alonso-Blanco et al., 2014). EC is the major light-absorbing component of atmospheric aerosol and is the second most important global warming agent after carbon dioxide (Bond et al., 2013). EC aerosols are primary sub-micron particulate matter emitted during incomplete combustion of fossil or bio-fuels. Aged EC aerosols have a fractal-like or globular structure and a wide vari- ety of organic and inorganic species adsorbed to them. OC is mainly a light-scattering component; however, it is also known to have a light-absorbing fraction called "brown carbon" $(\mathrm{BrC})$ that, similar to $\mathrm{BC}$, has been shown to be an important factor in aerosol radiative forcing (Andreae and Gelencsér, 2006; Andreae and Ramanathan, 2013; Saleh et al., 2014). In addition, due to the lensing effect, organic coatings can substantially modify the optical properties of EC in mixed particles. Thus, laboratory experiments have shown that the light absorption enhancement factor for internal mixtures of EC with organic and inorganic coatings can range from 1.3 to 3.5 (Schnaiter et al., 2005; Mikhailov et al., 2006; Zhang et al., 2008; Shiraiwa et al., 2010; Pokhrel et al., 2017).

Forest fires and biogenic emissions from coniferous trees and forest litter are the main sources of carbonaceous aerosols emitted into the atmosphere over boreal forests. The molecular composition of OC from biomass burning is still poor understood. It is known only that the thermal decomposition products of plant cellulose and lignin provide the largest contribution to the organic mass. Among them are sugar anhydrides, phenol compounds, alcohols, esters, aldehydes, and ketones (Kanakidou et al., 2005; Hoffer et al., 2006; Lappalainen et al., 2009; Mayol-Bracero et al., 2002; Fuzzi et al., 2007). In the spring and summer seasons, biogenic activity increases and VOCs, mainly isoprene, terpenes, and sesquiterpenes, are emitted to the atmosphere. These compounds form secondary organic aerosols as a result of photochemical oxidation and gas-to-particle conversion (Hallquist et al., 2009). A substantial fraction of boreal forest organic aerosol consists of water-soluble compounds and therefore contributes to hygroscopic growth and cloud condensation nuclei (CCN) activity (Huff Hartz et al., 2005; Ehn et al., 2007; Carrico et al., 2008; Cerully et al., 2011; Jaatinen et al., 2014; Paramonov et al., 2013; Mikhailov et al., 2015b).

Primary biological aerosols (PBAs) and their rupture products are another subset of organic particles, which are directly released from the biosphere into the atmosphere in the growing season. They comprise living and dead organisms (e.g. algae, archaea, bacteria), dispersal units (e.g. fungal spores and plant pollen), and various fragments or excretions (e.g. plant debris, brochosomes, and salt particles) (Després et al., 2012; Fröhlich-Nowoisky et al., 2016; Pöhlker et al., 2012). Their particle sizes range from nanometres up to about $1 / 10$ of a millimetre. They can serve as nuclei for cloud droplets, ice crystals, and precipitation, thus influencing the hydrological cycle and climate. In pristine air over vegetated regions, bioaerosols are likely to be an essential regulating factor in the formation of precipitation (Pöschl et al., 2010; Pummer et al., 2012, 2015; Steiner et al., 2015). In the atmosphere, bioparticles undergo internal and external mixing with other aerosols, including SOA, which can influence bioaerosol properties through SOA coatings (Hallquist 
et al., 2009; Pöschl et al., 2010; Huffman et al., 2012; Pöhlker et al., 2012).

In the northern latitudes of Eurasia, climate change occurs 1.5-2 times faster than the global average (Hansen et al., 2006; Groisman and Soja, 2009; IPCC, 2014). One consequence of these changes is an increase in VOC emissions, which is a precursor of SOA formation (Tunved et al., 2006). It is expected that the increase in the concentration of biogenic aerosols will provide negative climate feedbacks, involving aerosol-cloud and aerosol-carbon-cycle interactions (Kulmala et al., 2004, 2014; Andreae et al., 2008). These feedbacks may change the local structure of the atmospheric circulation, cloud properties, and the intensity of precipitation (Rosenfeld et al., 2013; Lappalainen et al., 2016). Precipitation, in turn, causes emissions bursts into the atmosphere of primary bioaerosols and submicron degradation products containing hygroscopic water-soluble inorganic ions (potassium, sodium, chlorides, and phosphates) and polysaccharides (hexoses, mannitol) (Morris et al., 2014; Bigg et al., 2015; Huffman et al., 2013). As temperatures increase, population outbreaks of tree-damaging insects can occur more frequently. The emissions of organic substances from damaged trees are significantly higher than from healthy trees (Bergström et al., 2014). For example, in the boreal environment, trees damaged by the pine borer (Neodiprion sertifer) emit 11 times more monoterpenes and 20 times more sesquiterpenes compared to healthy trees. As a result, the total mass of aerosols increased by $480 \%$ (local maximum), and the concentration of cloud condensation nuclei increased by $45 \%$ (Joutsensaari et al., 2015). It is also projected that increased growth of the forest area resulting from the surface temperature increase will be accompanied by more frequent forest fires (Shvidenko et al., 2011), which are powerful sources of aerosol particles and greenhouse gases (Paris et al., 2009; Janhäll et al., 2010; Smolyakov et al., 2014). In addition, industrial production and a steady increase in oil and gas production in Siberia will further increase the concentrations of aerosols in the Siberian air basin. It is therefore expected that the role of biogenic, pyrogenic, and anthropogenic aerosol emissions will grow with increasing temperatures, and their influence on climate change will be important both on the regional and global level (Kulmala et al., 2014; Lappalainen et al., 2016). In order to assess the magnitude and sign of these climatic effects, as well as to predict the possible consequences for Siberian ecosystems, it is necessary to provide a comprehensive long-term monitoring of the burden and composition of atmospheric aerosols in the region.

In 2006, the $300 \mathrm{~m}$ tower of the Zotino Tall Tower Observatory (ZOTTO) was established in central Siberia (Heimann et al., 2014). The background character and the geographical location of this station are appropriate conditions for studying atmospheric transport and coincident chemical transformation of polluted air on a wide range of spatial and temporal scales, particularly for assessing the potential influ- ence of emissions from various natural and anthropogenic sources on surface air composition over the large territory of Siberia. The remote location of ZOTTO in the middle of the Siberian taiga forest also makes it highly suitable for investigating the exchange of trace gases with this ecosystem and the production of aerosol by the boreal forest. Continuous measurements of comprehensive sets of atmospheric constituents in the gas and particle phase together with meteorological parameters have been carried out at ZOTTO since October 2006 (Kozlova et al., 2008; Heintzenberg et al., 2008). With regard to aerosol, a study of the representativeness of the ZOTTO facility and first analyses of the particle size distribution data can be found in Heintzenberg et al. (2008) and Heintzenberg and Birmili (2010); a statistical analysis of particle size distribution, particle absorption, and carbon monoxide (CO) data taken from the first 4 years of operation of the ZOTTO facility (September 2006 to January 2010) is given in Heintzenberg et al. (2011), together with seasonally dependent major air mass pathways and the related particle size distributions. An extended statistical analysis of aerosol properties including scattering coefficients, Ångström exponents, single scattering albedo, and backscattering ratios, as well as a CO data set with seasonal, weekly, and diurnal variations between September 2006 and December 2011 can be found in Chi et al. (2013).

In 2010, a filter-based sampler was mounted at the ZOTTO station for aerosol chemical analysis. In this study, we present the time series of carbonaceous aerosol measurements coupled with CO data for 5 years (2010-2014). We investigate the seasonal variations in $\mathrm{EC}, \mathrm{OC}$, WSOC (watersoluble organic carbon), and $\mathrm{CO}$. We analyse polluted, background and near-pristine periods as well as the most pronounced pollution events and their sources observed over the entire sampling campaign. The methodology is described in Sect. 2, and the seasonal features of temporal variations and air mass origins during pollution periods are discussed in Sect. 3.4 and 3.5. The background and near-pristine air masses and their characteristics are discussed in Sect. 3.6.

\section{Methods}

\subsection{Aerosol sampling}

The aerosol samples were collected from April 2010 to June 2014 at the Zotino Tall Tower Observatory facility, which is located near the Yenisei river at the eastern edge of the West Siberia Lowland in the boreal zone $\left(60.8^{\circ} \mathrm{N}\right.$ and $89.4^{\circ} \mathrm{E} ; 114 \mathrm{~m}$ a.s.1.), about $600 \mathrm{~km}$ north of the closest large city, Krasnoyarsk (950 000 inhabitants); the nearest village (Zotino) is about $20 \mathrm{~km}$ east of the site. The site lies in a vast region of boreal coniferous forest and bogs, and the ecosystem in the light taiga around the station is dominated by Pinus sylvestris forest stands (about $20 \mathrm{~m}$ height) on lichen-covered sandy soils. The heart of the station is a 
$300 \mathrm{~m}$ tower, which was designed for long-term atmospheric observations and where the sampled air masses are representative of a very large fetch area. A more detailed description of the ZOTTO facility is given elsewhere (Heimann et al., 2014). The climate is dominated by a large seasonal temperature cycle reaching from minima below $-55^{\circ} \mathrm{C}$ in winter to maxima above $30^{\circ} \mathrm{C}$ in summer.

Ambient air was sampled through a stainless steel inlet pipe with an internal diameter of about $2.9 \mathrm{~cm}$, reaching to the top of the tower at $300 \mathrm{~m}$ above ground. The inlet was designed for a laminar nominal sampling flow of $40 \mathrm{~L} \mathrm{~min}^{-1}$ (Birmili et al., 2007). Pre-installation calibration showed that particles with diameter $D_{\mathrm{p}}>50 \mathrm{~nm}$ are nearly perfectly transmitted through this pipe (Heintzenberg et al., 2008). Additional test measurements with supermicron aerosol particles have shown that the upper transmission size limit for the inlet system is $\sim 10 \mu \mathrm{m}$. Thus, carbonaceous species concentrations obtained in this study refer to aerosol particles with an upper limit of $\sim 10 \mu \mathrm{m}\left(\mathrm{PM}_{10}\right)$.

Aerosols were collected directly from the inlet line on $47 \mathrm{~mm}$ quartz fibre filters (2500QATUP, Pallflex) at a flow rate of $20 \mathrm{~L} \mathrm{~min}^{-1}$ using a sampler developed in-house. One of the difficulties in long-term filter sampling is the decision about the length of sampling periods. On one hand, the aerosol concentration at ZOTTO is very low during the nearpristine periods; therefore, days or even weeks of sampling time are needed in order to obtain enough material on the filter for analysis. On the other hand, extremely high aerosol concentrations were observed during pollution episodes (e.g. biomass burning) and a higher time resolution was needed for better characterisation of such episodes and to avoid overloading of the filters. As a result, the sampling time for each filter varied from $10 \mathrm{~h}$ during pollution events to $480 \mathrm{~h}$ during clean periods, and the median sampling time was $104 \mathrm{~h}$. A total of 292 samples were collected between April 2010 and June 2014. The exposed filters were sealed in aluminum foil and then placed in Ziploc bags. The samples were stored at $-18{ }^{\circ} \mathrm{C}$ before being analysed.

\subsection{Instrumentation}

\subsubsection{Carbon monoxide measurements}

$\mathrm{CO}$ was measured by UV resonance fluorescence, using a Fast-CO-Monitor (model AL 5002, Aerolaser GmbH, Germany). Details of the experimental setup and calibration are described elsewhere (Chi et al., 2013). The original CO data, measured with a frequency of $3 \mathrm{~s}$, were converted to $1 \mathrm{~h}$ averages to minimise uncertainties inherent in the data analysis methodology. These $\mathrm{CO}$ concentrations were further averaged over the aerosol sampling intervals. Technical problems occurred with the $\mathrm{CO}$ monitor during the following periods, resulting in gaps in the $\mathrm{CO}$ time series (Fig. 2): 7 July to 20 September 2010, 30 December 2010 to 11 April 2011,
28 June to 14 July 2011, 14 November to 27 December 2011, 17 February to 9 March 2012 and 15 May to 14 June 2012.

\subsubsection{Gravimetric PM measurement}

The aerosol mass concentrations were determined gravimetrically using a Mettler-Toledo micro balance model XP6 with $0.6 \mu \mathrm{g}$ sensitivity. Before being weighed, the filters were equilibrated for $24 \mathrm{~h}$ at a constant temperature of $23^{\circ} \mathrm{C}$ and a relative humidity between 35 and $45 \%$. Each filter was weighed at least three times before and after sampling. An anti-static U-Electrode (Mettler-Toledo) was used to remove electrostatic charge before weighing. The uncertainty (1 standard deviation) for the PM determination is estimated to be $10 \mu \mathrm{g}$ for $47 \mathrm{~mm}$ quartz filters.

\subsubsection{Organic carbon and elemental carbon analysis}

$\mathrm{OC}, \mathrm{EC}$, and total carbon $(\mathrm{TC}=\mathrm{OC}+\mathrm{EC})$ were measured by a thermal-optical transmission (TOT) technique (Birch and Cary, 1996), using a thermal-optical carbon analyser from Sunset Laboratory (OR, USA). The temperature protocol used was NIOSH5040 (National Institute for Occupational Safety and Health) with a preset maximum of $870^{\circ} \mathrm{C}$ (Birch, 1998). The uncertainty in the OC, EC, and TC measurements is provided for each individual filter sample by the calculation program. The uncertainty is made up of a constant part (which is $0.2 \mu \mathrm{g} \mathrm{C} \mathrm{cm}{ }^{-2}$ for OC and EC and $0.3 \mu \mathrm{g}$ $\mathrm{C} \mathrm{cm}^{-2}$ for TC) and of a variable part, which amounts to $5 \%$ of the OC, EC, or TC mass loading. To correct for the positive artifact in the OC determination, two quartz filters in series were used (Maenhaut and Claeys, 2007). Both filters were pre-baked at $850^{\circ} \mathrm{C}$. The carbon loading on the second filter was subtracted from that on the first filter. WSOC was determined by soaking part of the filter in water $(18.2 \mathrm{M} \Omega \mathrm{cm}$, Direct-Q3 UV, Millipore) for $12 \mathrm{~h}$; after drying the remaining carbon in the filter was measured using the Sunset instrument. In addition to the TOT method, a TOC- $\mathrm{V}_{\mathrm{CPH}}$ analyser (5000 A, Shimadzu) was also used for WSOC analysis. A two-step procedure consisting of measurements of watersoluble total carbon (WSTC) and water-soluble inorganic carbon (WSIC) was applied. WSOC is then calculated as the difference between WSTC and WSIC (Chi et al., 2009). The TOT and TOC- $\mathrm{V}_{\mathrm{CPH}}$ measurements of WSOC concentrations cover the date range from April 2010 to December 2011. In general, the agreement between the two methods during this time period was within $10 \%$. Due to fatal technical problems with the TOC- $\mathrm{V}_{\mathrm{CPH}}$, after December 2011 WSOC was measured only by the Sunset instrument. The estimated error of the WSOC concentrations using the TOT method is $10-15 \%$, depending on the filter loading, which results in a $12-17 \%$ error for the WSOC / OC ratio.

Organic matter $(\mathrm{OM})$ was estimated as $1.8 \cdot \mathrm{OC}$. The same OC-to-OM conversion factor of 1.8 had been used at the SMEAR II (Finland) (Maenhaut et al., 2011a) and K-puszta 
(Hungary) (Maenhaut et al., 2008) remote coniferous forest sites, providing the best agreement in the aerosol chemical mass closure calculations. As a result, the total carbonaceous matter (TCM) was calculated as $\mathrm{TCM}=1.8 \cdot \mathrm{OC}+\mathrm{EC}$. It should be noted that there is considerable variability in reported OM / OC ratios for organic compounds depending on the relative contribution of primary and secondary organic aerosol sources, with reported values ranging from 1.2 to 2.4 (Turpin and Lim, 2001). In this study OM and TCM are estimated and used mainly to illustrate their temporal variability. However, as will be shown below, the obtained estimates of the $\mathrm{TCM} / \mathrm{PM}_{10}$ ratio are reasonably consistent with published values for the sources of the pollution plumes.

It needs to be noted that the OC / EC analysis is very sensitive to the temperature protocol used and to the optical correction method (OC / EC split). NIOSH and IMPROVE (Interagency Monitoring of Protected Visual Environment) are the most widely applied thermal protocols, which differ in their temperature ramping regime and charring correction. The discrepancy between NIOSH- and IMPROVE-derived EC concentrations may vary in the range of a factor of 1.22 , depending on the source and aging of the samples (Chow et al., 2001; Cheng et al., 2014; Wu et al., 2016). Therefore, wherever possible, we compare OC / EC results from studies using the same or similar analytical methods.

In addition to the thermal-optical method, a singlewavelength $(574 \mathrm{~nm})$ particle soot absorption photometer (PSAP, Radiance Research, Seattle, USA) was used in this study for measuring the particulate light absorption coefficient to estimate equivalent black carbon $\left(\mathrm{BC}_{\mathrm{e}}\right)$ concentrations (Andreae and Gelencsér, 2006). Details about this method and the methodology used for data analysis and interpretation correction can be found in Chi et al. (2013). In this study, PSAP and TOT measurements cover the date range from 19 April 2010 to 15 May 2012; therefore, the PSAP data will be mainly used to quantify the correction factor $\left(\mathrm{BC}_{\mathrm{e}} / \mathrm{EC}\right.$ ratio) between the two methods used. The $\mathrm{BC}_{\mathrm{e}}$ mass concentration $\left(\mu \mathrm{g} \mathrm{m}^{-3}\right)$ can be calculated based on the relation:

$\sigma_{\mathrm{abs}}=\alpha_{\mathrm{abs}} B C_{\mathrm{e}}$,

where $\sigma\left(\mathrm{Mm}^{-1}\right)$ is the PSAP-measured absorption coefficient and $\alpha_{\mathrm{abs}}\left(\mathrm{m}^{2} \mathrm{~g}^{-1}\right)$ is the mass absorption efficiency. The commonly used value of $\alpha_{\mathrm{abs}}$ is $10 \mathrm{~m}^{2} \mathrm{~g}^{-1}$, as recommended by the PSAP manufacturer in their manual.

\subsection{Ancillary products}

Air mass trajectories were calculated with the Hybrid Single-Particle Lagrangian Integrated Trajectories (HYSPLIT) model (Stein et al., 2015) using the NCEP/NCAR meteorological archive data produced by the National Center for Environmental Prediction (NCEP) and the National Center for Atmospheric Research (NCAR) (2.5 horizontal resolution, 17 pressure levels) (Kalnay et al., 1996). The
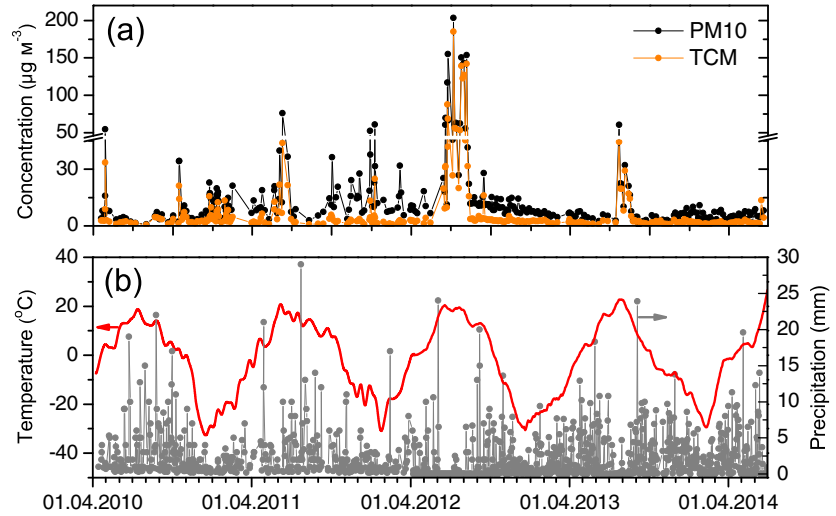

Figure 1. Seasonal and interannual variations in the aerosol particulate matter $\left(\mathrm{PM}_{10}\right)$ and TCM concentrations (a) and of dailyaveraged meteorological parameters (b): temperature - red line; precipitations - grey line and symbols.

trajectories were calculated for an arrival height of $300 \mathrm{~m}$ above ground level, which corresponds to the aerosol sampling height at the ZOTTO station. The NCEP/NCAR meteorological data set was also used to estimate the mixing layer depth (MLD) and accumulated precipitation along the trajectory (APT). We used the APT data as a measure of wet removal of aged carbonaceous species (Kondo et al., 2011a; Matsui et al., 2011; Kanaya et al., 2016). In some cases, the APT values were averaged by dividing the total precipitation along all the trajectories for a selected time period by the number of these trajectories (Table 4).

Fire (hot spot) images were obtained from the Moderate Resolution Imaging Spectroradiometer (MODIS) instruments at $1 \mathrm{~km}$ resolution (Giglio et al., 2003) distributed by the Fire Information for Resource Management System (FIRMS). The probability of fire detection is strongly dependent upon temperature and area. Thus, local fires with a combustion temperature above $1000^{\circ} \mathrm{C}$ can be detected with a flaming areas less than $100 \mathrm{~m}^{2}$, while smoldering fires are difficult to detect (Giglio et al., 2003). In particular, MODIS products have been successfully used for monitoring the flare sites associated with the production of crude oil (Elvidge et al., 2011; Anejionu et al., 2015).

\section{Results and discussion}

\subsection{PM, TCM, and regional meteorology}

The time series of $\mathrm{PM}_{10}$ and TCM concentrations together with daily averaged meteorological parameters during the sampling period are shown in Fig. 1. Visual analysis indicates that the highest concentrations of $\mathrm{PM}_{10}$ and TCM, observed in the spring and summer periods (Fig. 1a), correspond to high temperatures and lower levels of precipitation (Fig. 1b). It is also seen that TCM was the dominant 
species in particulate mass during summertime. As will be shown below, biomass burning is the main source of polluted air masses arriving at the ZOTTO site in the summer season. Our overall median $\mathrm{PM}_{10}$ concentration (25-75th percentiles) was $7.9(5.1-14.4) \mu \mathrm{g} \mathrm{m}^{-3}$. This is comparable to the annual-mean $\mathrm{PM}_{10}$ values ranging from 8 to $16 \mu \mathrm{g} \mathrm{m}^{-3}$ at northern European rural background stations reported by Querol et al. (2004) but slightly higher than the annualmean European continental background $\mathrm{PM}_{10}$ concentration of 7.0 $\pm 4.1 \mu \mathrm{g} \mathrm{m}^{-3}$ obtained by Van Dingenen et al. (2004).

Our measurements of the carbonaceous species can be compared with those from the Hyytiälä (Finland) and Kpuszta (Hungary) remote European forested sites, which used the same EC / OC thermal protocol (Chi, 2009; Maenhaut et al., 2011b). Table 1 shows that the summertime EC concentration at ZOTTO $\left(0.13 \mu \mathrm{g} \mathrm{m}^{-3}\right)$ is comparable to measurements at Hyytiälä $\left(0.12 \mu \mathrm{g} \mathrm{m}^{-3}\right)$ and K-puszta $(0.16-$ $0.19 \mu \mathrm{g} \mathrm{m}^{-3}$ ), whereas the median OC and WSOC concentrations at ZOTTO are higher than those at the European sites. Elevated concentrations of the organic species at the ZOTTO site can be attributed to the strong influence of biomass burning events during the summer season. This is particularly reflected in the wide concentration range of OC and WSOC, varying from 0.3 to $106 \mu \mathrm{g} \mathrm{m}^{-3}$ and 0.2 to $45 \mu \mathrm{g} \mathrm{m}^{-3}$, respectively (Table 1 ). In summertime, the WSOC / OC ratio at the ZOTTO site was $0.65 \pm 0.13$. This value is close to that for the Hyytiälä boreal forest site $(0.62 \pm 0.09)$ and slightly higher than for the K-puszta station $(0.57 \pm 0.11)$ (Table 1$)$. The obtained WSOC / OC ratio is typical for non-urban sites surrounded by pine forest. It has been documented that in the summer season aged secondary organic aerosols produced by monoterpene oxidation as well as biomass burning organic particulate matter contain a high fraction of WSOC, ranging from 0.5 to 0.8 (Saxena et al., 1995; Kiss et al., 2002; Pöschl, 2005; Pio et al., 2007; Timonen et al., 2008).

Table 1 also provides summary statistics for carbonaceous species at ZOTTO compared with those reported for highaltitude remote sites. The annual average value of EC is within the concentration range observed at the European high-altitude sites and lower than those from Chinese stations, whereas the yearly-average OC and WSOC concentrations at ZOTTO noticeably exceed those obtained at both the European and Chinese sites. As a result, our EC / TC ratio is lower than those at the high-altitude stations, probably because of higher contributions from VOC oxidation at ZOTTO. Note, as mentioned above, that the EC discrepancy can be partially caused by the different thermal protocols used for EC / OC analysis.

Overall, the comparative analysis of the carbonaceous species concentrations suggests that the aerosols sampled at ZOTTO during our study period were generally representative of a fairly clean region.

\subsection{Estimation of polluted, background, and clean periods}

Siberia is a highly diverse region, where relatively clean periods $\left(\mathrm{PM}_{10}<1 \mu \mathrm{g} \mathrm{m}^{-3}\right)$ alternate with heavily polluted intervals $\left(\mathrm{PM}_{10}>50 \mu \mathrm{g} \mathrm{m}^{-3}\right)$ (Fig. 1a). Air masses that are influenced by regional emission sources are not representative of well-mixed background air. Data filtering is therefore an important step in analysing the data. In our analysis, we therefore differentiate between polluted, background, and clean periods.

We refer to "background" conditions as an atmospheric state without the detectable influence of local or regional pollution sources but affected by emissions of natural origin as well as by pollution transported from very distant sources (Andreae, 2007; Chi et al., 2013; Mikhailov et al., 2015b). To define the concentrations of the measured species representing background air (or the other way around to define the polluted periods), we made use of a non-parametric statistical approach named REBS (robust extraction of background signal). This technique has been previously applied for the identification of background $\mathrm{CO}$ concentrations for long-term measurements at the high alpine background site at Jungfraujoch (Ruckstuhl et al., 2012), at a global background station in China (Zhang et al., 2011), and at the ZOTTO site (Chi et al., 2013). Here, we use a bandwidth of 3 months following the suggestion of Ruckstuhl et al. (2012). Figure 2 shows the time series of the $\mathrm{CO}$ mixing ratio, $\mathrm{EC}, \mathrm{OC}$, and $\mathrm{PM}_{10}$ concentrations at ZOTTO, with the red baseline indicating REBS background concentrations $g_{i}\left(t_{i}\right)$. All concentrations $C_{i}\left(t_{i}\right) \leq g_{i}\left(t_{i}\right)+3 \sigma$ are classified as background measurements; all other observations are classified as "polluted". Here, $\sigma$ is the goodness of fit (Ruckstuhl et al., 2012).

In contrast to background conditions, the term "pristine" implies that all aerosol sources arise from natural emissions. It has been argued that regions in which aerosols are totally unperturbed by air pollution no longer exist in today's atmosphere (Andreae, 2007). Therefore, the terms "near-pristine" or "clean" are commonly used to denote relatively clean air. Both EC (or BC) and CO are indicators of combustion and pollution, and their concentrations are frequently used to separate near-pristine from polluted periods (Andreae, 2007; Chi et al., 2013; Hamilton et al., 2014). It should be noted, however, that it is not always possible to define a pristine environment based on $\mathrm{CO}$ concentrations at a particular site, since $\mathrm{CO}$ can be produced by biogenic sources directly or by means of $\mathrm{CH}_{4}$ and NMVOC (non-methane volatile organic compound) oxidation (Gaubert et al., 2016, and references therein). The concentration of $\mathrm{EC}$ (or $\mathrm{BC}$ ) is more reliable for air quality analysis, as EC is a primary pollutant, emitted directly into the atmosphere during incomplete combustion of carbonaceous fuels. During long-range transport it can be removed by precipitation scavenging together with other pollution species, returning the aerosol burden to near-pristine conditions. Therefore, in this study the 
Table 1. Mean (with $\pm \mathrm{SD}$, where available) and median (min-max) concentrations $\left(\mu \mathrm{g} \mathrm{m}^{-3}\right.$ ) of EC, OC, and WSOC, together with EC / TC and WSOC / OC ratios measured at remote background sites compared with ZOTTO data obtained from April 2010 to June 2014. ND: no data.

\begin{tabular}{|c|c|c|c|c|c|c|c|}
\hline \multirow[t]{2}{*}{ Site } & \multirow[t]{2}{*}{ Sampling period } & \multirow{2}{*}{$\begin{array}{l}\mathrm{EC} \\
\mu \mathrm{g} \mathrm{m}^{-3}\end{array}$} & \multirow{2}{*}{$\begin{array}{l}\mathrm{OC} \\
\mu \mathrm{g} \mathrm{m}^{-3}\end{array}$} & \multirow{2}{*}{$\begin{array}{l}\text { WSOC } \\
\mu \mathrm{g} \mathrm{m}^{-3}\end{array}$} & \multirow[t]{2}{*}{$\mathrm{EC} / \mathrm{TC}$} & \multirow[t]{2}{*}{ WSOC / OC } & \multirow[t]{2}{*}{ Reference } \\
\hline & & & & & & & \\
\hline Hyytiälä, Finland & 02/08-29/08/2007 & $0.12(0.01-0.34)$ & $1.45(0.24-3.9)$ & $0.91(0.11-2.5)$ & $0.07 \pm 0.02$ & $0.62 \pm 0.09$ & Chi $(2009)^{\mathrm{a}}$ \\
\hline K-puszta, Hungary & $04 / 06-10 / 07 / 2003$ & $0.19(0.08-0.59)$ & $3.7(1.61-5.7)$ & $2.1(0.73-3.8)$ & $0.06 \pm 0.02$ & $0.57 \pm 0.11$ & Chi $(2009)^{\mathrm{a}}$ \\
\hline K-puszta, Hungary & $24 / 05-29 / 06 / 2006$ & $0.16(0.02-0.45)$ & $2.5(0.85-5.9)$ & $1.37(0.38-3.8)$ & $0.07 \pm 0.03$ & $0.55 \pm 0.11$ & Chi (2009) ${ }^{\mathrm{a}}$ \\
\hline ZOTTO, Russia & 2010-2014, summer & $0.13(0.02-4.0)$ & $4.4(0.3-106)$ & $3.3(0.2-45)$ & $0.03 \pm 0.01$ & $0.65 \pm 0.13$ & This study ${ }^{a}$ \\
\hline \multicolumn{8}{|c|}{ High-altitude remote sites } \\
\hline Mt. Sonnblick, Austria $(3160 \mathrm{~m})$ & $10 / 2003-10 / 2005$ & 0.15 & 0.93 & 0.60 & 0.20 & 0.65 & Pio et al. $(2007)^{b}$ \\
\hline Puy de Dôme, France $\quad(1450 \mathrm{~m})$ & $10 / 2003-10 / 2005$ & 0.22 & 1.60 & 1.08 & 0.12 & 0.68 & Pio et al. (2007) ${ }^{\mathrm{b}}$ \\
\hline Schauinsland, Germany (1205 m) & $10 / 2003-10 / 2005$ & 0.29 & 2.39 & 1.86 & 0.11 & 0.78 & Pio et al. (2007) ${ }^{b}$ \\
\hline Zhuzhang, China $\quad(3583 \mathrm{~m})$ & 06/2004-05/2005 & $0.34 \pm 0.18$ & $3.1 \pm 0.9$ & ND & $0.10 \pm 0.05$ & ND & Qu et al. (2009) \\
\hline Akdala, China & $06 / 2004-05 / 2005$ & $0.35 \pm 0.31$ & $2.9 \pm 1.6$ & $\mathrm{ND}$ & $0.11 \pm 0.10$ & ND & Qu et al. $(2009)^{\mathrm{c}}$ \\
\hline Qinghai Lake, China & $11 / 2011-11 / 2012$ & $0.84 \pm 0.46$ & $3.46 \pm 1.64$ & $1.55 \pm 0.77$ & $0.20 \pm 0.14$ & $0.45 \pm 0.26$ & Zhao et al. $(2015)^{\mathrm{c}}$ \\
\hline ZOTTO, Russia & $04 / 2010-06 / 2014$ & $0.25 \pm 0.43$ & $4.66 \pm 12.0$ & $2.69 \pm 6.0$ & $0.08 \pm 0.06$ & $0.63 \pm 0.14$ & This study ${ }^{a}$ \\
\hline & & $0.12(0.02-4.0)$ & $1.46(0.29-106)$ & $0.92(0.05-45)$ & & & \\
\hline
\end{tabular}

Methods, protocol used for EC / OC: ${ }^{a}$ thermal-optical, NIOSH (TOT); ${ }^{b}$ thermal-optical, preheating at $600^{\circ} \mathrm{C}$ without $\mathrm{O}_{2} ;{ }^{\mathrm{c}}$ thermal-optical, IMPROVE (TOR). TOT (TOR), thermal-optical transmittance (reflectance)

periods with EC concentrations below the limit of detection $\left(0.02 \pm 0.01 \mu \mathrm{gC} \mathrm{m}^{-3}\right)$ are classified as clean or nearpristine.

Table 2 shows the seasonal concentrations of $\mathrm{CO}, \mathrm{PM}_{10}$, and carbonaceous species for polluted, background, and clean conditions averaged over the full sampling period (2010-2014). We compared our carbon monoxide concentrations with those obtained at the ZOTTO site from 2006 to 2011 by Chi et al. (2013). During background and clean periods the $\mathrm{CO}$ concentrations are in agreement within about $10 \%$, while the polluted CO mixing ratios disagree markedly in all seasons, especially in the summer and fall periods, where the averaged concentrations exceed those obtained by Chi et al. (2013) by factors of 6.5 and 1.6, respectively. As a consequence, the frequencies of polluted periods are higher than those obtained in the Chi et al. (2013) study. Accordingly, the frequencies of clean periods are significantly lower (Table 2). Besides more strong pollution events observed from 2010 to 2014, our low frequencies of clean periods also arise from a more rigid criterion used for clean period detection. In Chi et al.'s (2013) work, clean periods were selected based on the aerosol absorption coefficients; i.e. the time intervals when their values were below $1 \mathrm{Mm}^{-1}$ $\left(\sim 0.1 \mu \mathrm{gC} \mathrm{m}^{-3}\right)$ were classified as clean. In contrast, in this study the clean periods were defined by EC concentrations below the detection limit of $0.02 \pm 0.01 \mu \mathrm{gC} \mathrm{m}{ }^{-3}$.

Table 2 also shows that in the cold period (winter, spring, and fall) the $\mathrm{PM}_{10}, \mathrm{OC}$, and WSOC concentrations as well as the WSOC / OC and TCM / PM ratios obtained for background and clean periods show only small seasonal differences. In these seasons, aerosol particles come to ZOTTO mainly from pollution sources, since in the cold period the air temperature is below or close to $0{ }^{\circ} \mathrm{C}$ and biogenic activity is suppressed. Previous studies (Chi et al., 2013) have shown that in winter, pristine-period particles and pollution particles have a comparable footprint and size distribution. Chi et al. (2013) suggested that in the cold seasons the main sources of the observed particles at the ZOTTO site are the same during clean and polluted periods and that the different concentrations are mostly due to different degrees of dilution and removal. We concur with their suggestion that the differences between polluted and clean concentrations in the cold seasons (Table 2) are mainly the result of changes in meteorological conditions (wind direction, precipitations). Note also that across all seasons, the WSOC / OC ratio ranged from 0.5 to 0.7 (Table 2). This interval is typical for aged primary and secondary organic aerosols, which have undergone chemical transformations (oxidation, nitration, hydrolysis, and photolysis) during long-range transport (Pöschl, 2005; Timonen et al., 2008; Jimenez et al., 2009; Saarnio et al., 2010).

\subsection{Characterisation of polluted air}

As described in Sect. 3.3, the entire ZOTTO data set was separated into polluted and background periods using the REBS method. In order to evaluate the degree of pollution, we used the enhancement factor $(\mathrm{EnF})$, defined here as the ratio of the median concentration of a species during a polluted period to the background concentration. The monthly variations in $\mathrm{EnF}$ for $\mathrm{PM}, \mathrm{EC}$, and $\mathrm{OC}$ are shown in Fig. 3. It is seen that the EnFs of all species correlate quite well, showing high values of the EnF during the summer months and lower values in the cold season. In particular, the EnF for EC indicates that minimal levels of pollution were observed in March and April with an EnF of $\sim 1.7$, followed by the winter months $(\mathrm{EnF} \sim 3)$, while maximal pollution is present in summer with $\mathrm{EnF}=20,51$, and 5.4 for June, July, and August, respectively. In general, Fig. 3 clearly illustrates that during the whole year, the air masses arriving at ZOTTO contain pollution components from regional and local sources. 
Table 2. Seasonal concentration ( $\pm \mathrm{SD}$ ) of $\mathrm{CO}, \mathrm{PM}_{10}$, and carbonaceous species together with ratios and frequency representative of polluted, background, and clean periods obtained at ZOTTO from April 2010 to June 2014.

\begin{tabular}{|c|c|c|c|c|c|c|c|c|c|c|}
\hline \multirow[t]{2}{*}{ Season and conditions } & \multicolumn{2}{|c|}{ Frequency $^{\mathrm{a}}$} & $\mathrm{CO}^{\mathrm{b}}$ & $\mathrm{CO}$ & $\mathrm{PM}_{10}$ & $\mathrm{EC}$ & $\mathrm{OC}$ & WSOC & WSOC / OC & TCM / PM \\
\hline & \multicolumn{2}{|c|}{$\%$} & $\mathrm{ppb}$ & $\mathrm{ppb}$ & $\mu \mathrm{g} \mathrm{m}^{-3}$ & $\mu \mathrm{g} \mathrm{m}^{-3}$ & $\mu \mathrm{g} \mathrm{m}^{-3}$ & $\mu \mathrm{g} \mathrm{m}^{-3}$ & & \\
\hline \multicolumn{11}{|c|}{ Winter } \\
\hline Polluted & 75 & 47 & $181 \pm 24$ & $204 \pm 36$ & $16.6 \pm 12.6$ & $0.30 \pm 0.20$ & $2.7 \pm 1.6$ & $1.3 \pm 1.1$ & $0.52 \pm 0.17$ & $0.38 \pm 0.24$ \\
\hline Background & 25 & 53 & $148 \pm 21$ & $151 \pm 20$ & $5.8 \pm 1.9$ & $0.08 \pm 0.03$ & $0.94 \pm 0.38$ & $0.62 \pm 0.34$ & $0.61 \pm 0.11$ & $0.33 \pm 0.18$ \\
\hline Clean & 1 & 23 & $139 \pm 14$ & No data & $6.5 \pm 2.9$ & $0.028 \pm 0.004$ & $0.75 \pm 0.38$ & $0.46 \pm 0.27$ & $0.59 \pm 0.11$ & $0.13 \pm 0.07$ \\
\hline \multicolumn{11}{|c|}{ Spring } \\
\hline Polluted & 42 & 19 & $160 \pm 32$ & $183 \pm 24$ & $14.3 \pm 11.6$ & $0.23 \pm 0.27$ & $3.1 \pm 4.1$ & $1.4 \pm 1.3$ & $0.65 \pm 0.12$ & $0.36 \pm 0.16$ \\
\hline Background & 58 & 79 & $155 \pm 14$ & $153 \pm 19$ & $5.5 \pm 2.9$ & $0.07 \pm 0.03$ & $0.97 \pm 0.31$ & $0.61 \pm 0.25$ & $0.63 \pm 0.13$ & $0.36 \pm 0.16$ \\
\hline Clean & 9 & 36 & $138 \pm 12$ & $137 \pm 27$ & $7.4 \pm 5.7$ & $0.02 \pm 0.01$ & $0.81 \pm 0.05$ & $0.45 \pm 0.14$ & $0.56 \pm 0.16$ & $0.31 \pm 0.26$ \\
\hline \multicolumn{11}{|c|}{ Summer } \\
\hline Polluted & 61 & 20 & $103 \pm 41$ & $667 \pm 711$ & $59.4 \pm 53.1$ & $0.84 \pm 0.92$ & $26.1 \pm 26.7$ & $13.9 \pm 11.7$ & $0.61 \pm 0.13$ & $0.75 \pm 0.17$ \\
\hline Background & 39 & 80 & $92 \pm 5$ & $114 \pm 15$ & $6.3 \pm 3.9$ & $0.03 \pm 0.02$ & $1.24 \pm 0.57$ & $0.89 \pm 0.45$ & $0.69 \pm 0.12$ & $0.41 \pm 0.20$ \\
\hline Clean & 17 & 32 & $89 \pm 14$ & $103 \pm 12$ & $7.4 \pm 4.7$ & $0.02 \pm 0.02$ & $1.36 \pm 0.56$ & $0.90 \pm 0.41$ & $0.64 \pm 0.10$ & $0.43 \pm 0.23$ \\
\hline \multicolumn{11}{|c|}{ Fall } \\
\hline Polluted & 42 & 16 & $117 \pm 16$ & $192 \pm 61$ & $17.6 \pm 10.0$ & $0.19 \pm 0.12$ & $3.4 \pm 3.3$ & $2.2 \pm 1.8$ & $0.64 \pm 0.12$ & $0.34 \pm 0.18$ \\
\hline Background & 58 & 84 & $108 \pm 19$ & $118 \pm 14$ & $7.3 \pm 4.6$ & $0.06 \pm 0.02$ & $1.32 \pm 0.53$ & $0.96 \pm 0.47$ & $0.70 \pm 0.10$ & $0.43 \pm 0.29$ \\
\hline Clean & 10 & 28 & $96 \pm 4$ & $108 \pm 6$ & $7.8 \pm 4.9$ & $0.02 \pm 0.02$ & $1.44 \pm 0.42$ & $1.00 \pm 0.40$ & $0.68 \pm 0.11$ & $0.39 \pm 0.26$ \\
\hline
\end{tabular}

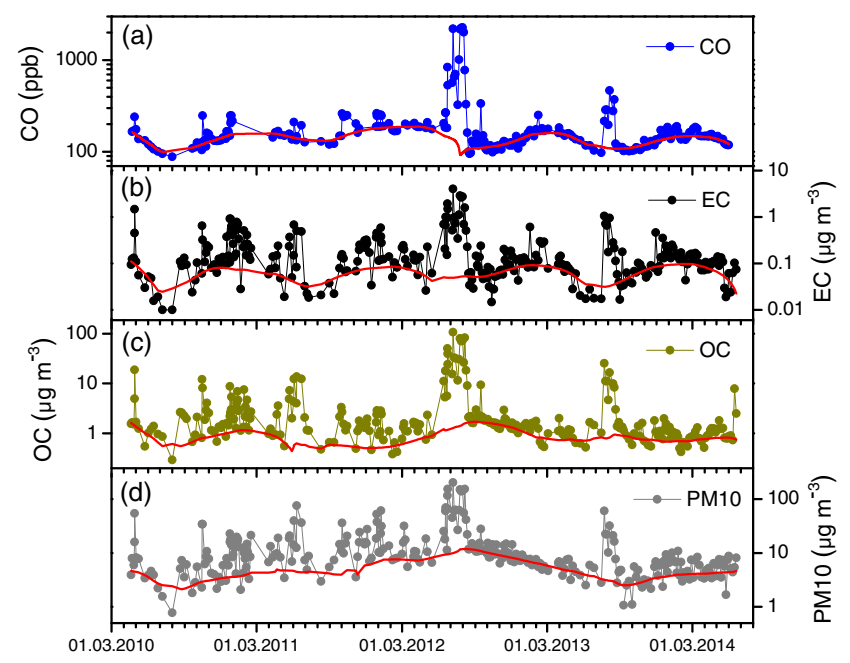

Figure 2. Time series of CO (a), EC (b), OC (c), and $\mathrm{PM}_{10}(\mathbf{d})$ concentrations at ZOTTO and respective background concentrations (red solid line) as identified by the REBS algorithm (Ruckstuhl at al., 2012).

Biomass burning and fossil fuel combustion processes emit $\mathrm{CO}$, $\mathrm{OC}$, and $\mathrm{EC}(\mathrm{BC})$, but the emission ratio between these species differs by combustion type and burning condition (Kondo et al., 2006; Wang et al., 2011; Zhang et al., 2013). We used the $\Delta \mathrm{OC} / \triangle \mathrm{EC}$ and $\Delta \mathrm{EC} / \Delta \mathrm{CO}$ relationships observed at ZOTTO as an additional indicator of the origin of pollution emissions (Andreae and Merlet, 2001;

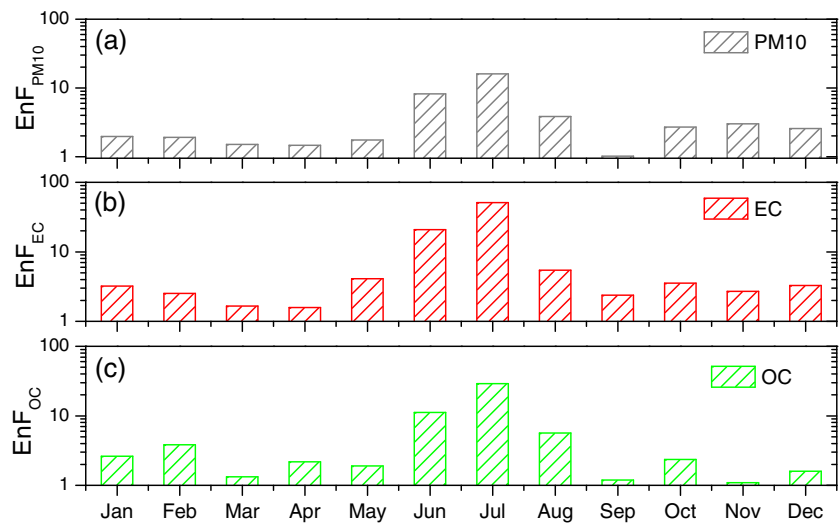

Figure 3. Monthly variation in the $\mathrm{EnF}$ of $\mathrm{PM}_{10}$ (a), $\mathrm{EC}$ (b), and OC (c) at ZOTTO from April 2010 to June 2014.

Kondo et al., 2011a; Wang et al., 2011). Figures 4 and 5 show the seasonal relationships between $\triangle \mathrm{EC}$ and $\triangle \mathrm{OC}$ and between $\Delta \mathrm{EC}$ and $\Delta \mathrm{CO}$, respectively. The pollution concentration enhancements ( $\Delta$ values) were calculated as the difference between the measured concentrations and the REBSdefined background values.

Figure 4 shows strong correlations between $\triangle \mathrm{OC}$ and $\triangle \mathrm{EC}$ concentrations throughout all seasons, but the $\triangle \mathrm{OC} / \triangle \mathrm{EC}$ slopes are different. The good correlation between $\triangle \mathrm{OC}$ and $\triangle \mathrm{EC}$ implies that both components are emitted into to the atmosphere from the same combustion sources, while the significant seasonal differences between 

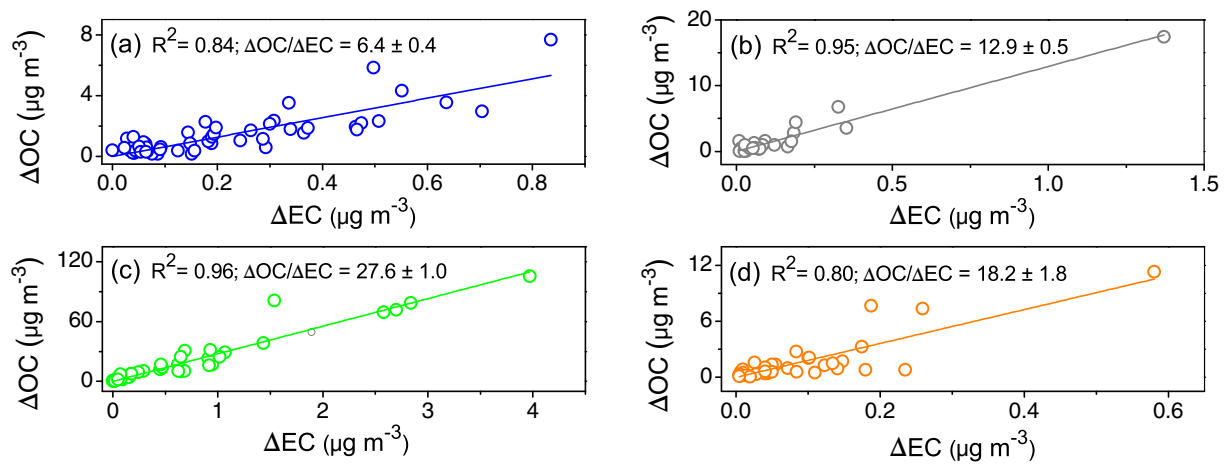

Figure 4. Seasonal relationship between EC and OC: winter (a), spring (b), summer (c), and fall (d) during pollution periods, using all data obtained at ZOTTO from April 2010 to June 2014. The linear fit is shown for reference: $R^{2}-$ coefficient of determination; $\Delta$ OC / $\Delta E C$ slope $\pm 1 \mathrm{SD}$. The polluted $\triangle \mathrm{EC}$ and $\triangle \mathrm{OC}$ concentrations were calculated as the difference between measured and REBS-defined background concentrations.
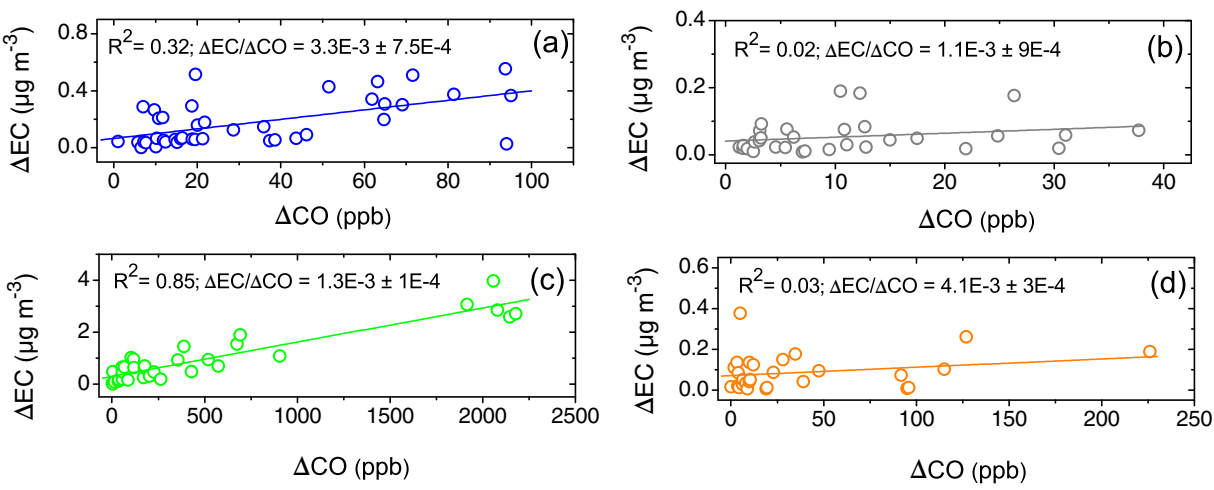

Figure 5. Seasonal relationship between $\triangle \mathrm{EC}$ and $\triangle \mathrm{CO}$ : winter (a), spring (b), summer (c), and fall (d) during pollution periods, using all data obtained at ZOTTO from April 2010 to June 2014. The linear fit is shown for reference: $R^{2}-$ coefficient of determination; $\Delta$ OC / $\Delta$ EC slope $\pm 1 \mathrm{SD}$ in $\mu \mathrm{g} \mathrm{m}^{-3} \mathrm{ppb}^{-1}$. The polluted $\triangle \mathrm{EC}$ and $\triangle \mathrm{OC}$ concentrations were calculated as the difference between measured and REBSdefined background concentrations.

the regression coefficients suggest that the sources of carbonaceous aerosol are different between seasons. Depending on fire intensity and the type of fire (e.g. flaming vs. smoldering), the OC / EC ratio for boreal forest fires varies over a wide range (Table 3). From prescribed burns conducted in boreal forests (northern Ontario, Canada), Mazurek et al. (1991) reported a range of $10-18$ and $21-95$ for full-flaming and smoldering fire conditions, respectively. A chamber experiment conducted with typical Siberian biomass (pine) showed that the $\mathrm{OC} / \mathrm{EC}$ ratios for $\mathrm{PM}_{10}$ in fresh (aged) smoke for flaming and smoldering are $0.3(2.3)$ and 181 (126), respectively (Popovicheva et al., 2015). In addition, the OC / EC ratios for fresh forest debris smoke were found to be 0.6 and 35 in flaming and smoldering fires, respectively. In mixed boreal wildfires, the mean OC / EC ratios for $\mathrm{PM}_{10}$ in fresh smoke plumes were reported as 6.7 (Saarnio et al., 2010), 6.5 (Popovicheva et al., 2015), and 15 (Lee at al., 2005). For aged smoke particles, Yan et al. (2008) reported a value of 25.6, which is close to our summer aver- aged $\Delta \mathrm{OC} / \Delta \mathrm{EC}$ ratio of $27.6 \pm 1.0$ obtained for the entire sampling campaign (Fig. 4c).

In contrast to open vegetation fires, industrial biomass and fossil fuel combustion as well as domestic fuel combustion generally exhibit smaller OC / EC ratios. Close to sources, this ratio ranged from 0.7 to 5 depending on the fuel burned and the combustion technology used (Andreae and Merlet, 2001; Lim and Turpin, 2002; Andreae et al., 2008b; Saarikoski et al., 2008). It should be noted that the aging of air masses tends to increase the OC / EC ratio of the aerosol due to oxidation and condensation of organic material (Burtscher et al., 1993; Andreae et al., 2008b; Konovalov et al., 2015, 2017). On the whole, our seasonal $\Delta \mathrm{OC} / \Delta \mathrm{EC}$ ratios are in agreement with the literature (Table 3), indicating that the low value of $6.4 \pm 0.4$ obtained in wintertime (Fig. 4a) is mostly the result of local and regional anthropogenic emissions from fossil fuel and domestic combustion, while the high value of $27.6 \pm 1.0$ (Fig. 4c) observed in summer is indicative of open biomass burning, probably with a 
Table 3. Comparison of $\Delta \mathrm{OC} / \Delta \mathrm{EC}$ and $\Delta \mathrm{OC} / \Delta \mathrm{EC}$ at ZOTTO with values obtained from previous data sources. $\mathrm{F}, \mathrm{S}$, and $\mathrm{M}$ stand for flaming, smoldering, and mixed burning mode, respectively.

\begin{tabular}{|c|c|c|c|c|c|}
\hline Location and study period & $\begin{array}{l}\text { Instrument, method, } \\
\text { protocol for EC }\end{array}$ & Fuel type & $\Delta \mathrm{OC} / \Delta \mathrm{EC}$ & $\begin{array}{l}\Delta \mathrm{EC} / \Delta \mathrm{CO} \\
\left(\mathrm{ng} \mathrm{m}^{-3} \mathrm{ppb}^{-1}\right)\end{array}$ & References \\
\hline \multicolumn{6}{|c|}{ Urban, combustion } \\
\hline ZOTTO, winter pollution & $\begin{array}{l}\text { Thermal-optical, } \\
\text { NIOSH(TOT) }^{\mathrm{a}}\end{array}$ & Fossil fuel & $3.9 \pm 0.6$ & $5.8 \pm 0.7$ & This study \\
\hline Guangzhou, Oct-Nov 2004 & $\begin{array}{l}\text { Thermal-optical, } \\
\text { NIOSH(TOT) }\end{array}$ & Fossil fuel & $3.2 \pm 1.9$ & $7.9 \pm 0.2$ & Andreae et al. (2008b) \\
\hline Guangzhou, July 2006 & $\begin{array}{l}\text { Thermal-optical, } \\
\text { NIOSH(TOT) }\end{array}$ & Fossil fuel & & $5.4 \pm 0.4$ & Verma et al. (2010) \\
\hline Taiyuan, Dec 2005-Feb 2006 & $\begin{array}{l}\text { Thermal-optical, } \\
\text { NIOSH(TOT) }\end{array}$ & Fossil fuel & $7.0 \pm 3.9$ & & Meng et al. (2007) \\
\hline Taiyuan, Sep 2009-Feb 2010 & $\begin{array}{l}\text { Thermal-optical, } \\
\text { IMPROVE(TOR) }\end{array}$ & Fossil fuel & $5.4 \pm 1.5$ & & Li et al. (2012) \\
\hline Beijing, Nov 2005-Oct 2006 & $\begin{array}{l}\text { Thermal-optical, } \\
\text { NIOSH(TOT) }\end{array}$ & Fossil fuel & & $3.5-5.8$ & Han et al. (2009) \\
\hline Xi'an, Dec 2003-Feb 2004 & $\begin{array}{l}\text { Thermal-optical, } \\
\text { IMPROVE(TOR) }\end{array}$ & Fossil fuel & $3.5-5.1$ & & Cao et al. (2005) \\
\hline Tokyo, 2003-2005 & $\begin{array}{l}\text { Thermal-optical, } \\
\text { NIOSH(TOT) }\end{array}$ & Fossil fuel & & $5.7 \pm 0.9$ & Kondo et al. (2006) \\
\hline Houston, Dallas, Sep-Oct 2006 & $\begin{array}{l}\mathrm{SP} 2^{\mathrm{c}} \text {, laser-induced } \\
\text { incandescence }\end{array}$ & Fossil fuel & & $5.8 \pm 1.0$ & Spackman et al. (2008) \\
\hline Beijing, Jan-Feb 2009 & $\begin{array}{l}\text { Thermal-optical, } \\
\text { IMPROVE-A }\end{array}$ & Fossil fuel & $6.1 \pm 1.2$ & & Cheng et al. (2011) \\
\hline $\mathrm{NCP}^{\mathrm{b}}$, Apr-Oct 2010 & $\operatorname{COSMOS}^{\mathrm{d}}$, heated- & Fossil fuel & & $8.4 \pm 0.4$ & Wang et al. (2011) \\
\hline NCP and Beijing, Apr-Oct 2010 & inlet light adsorption & & & $9.5 \pm 2.0$ & \\
\hline \multicolumn{6}{|c|}{ Coniferous forest fires } \\
\hline ZOTTO, summer fire episodes & $\begin{array}{l}\text { Thermal-optical, } \\
\text { NIOSH(TOT) }\end{array}$ & Borealforest & $26.2 \pm 0.1$ & $1.3 \pm 0.1$ & This study \\
\hline Ontario Canada, August 1989, prescribed burning & Thermal-optical & Borealforest & $\begin{array}{l}10-18(\mathrm{~F}) \\
21-95(\mathrm{~S})\end{array}$ & & Mazurek et al. (1991) \\
\hline Canada, 29 June-10 July 2008 & $\begin{array}{l}\mathrm{SP} 2^{\mathrm{c}} \text {, laser-induced } \\
\text { incandescence }\end{array}$ & Boreal forest & & $\begin{array}{l}1.7 \pm 0.1(\mathrm{~S}) \\
3.4 \pm 1.6(\mathrm{~F})\end{array}$ & Kondo et al. (2011a) \\
\hline $\begin{array}{l}\text { Georgia (US), April 2004, } \\
\text { prescribed burning }\end{array}$ & $\begin{array}{l}\text { Thermal-optical, } \\
\text { NIOSH(TOT) }\end{array}$ & Pine-dominated forest & $\begin{array}{l}15.4 \pm 10.3(\mathrm{~F}) \\
15.4 \pm 10.4(\mathrm{~S})\end{array}$ & & Lee et al. (2005) \\
\hline Alaska, Missoula, Montana, (combustion chamber) & $\begin{array}{l}\text { Thermal-optical, } \\
\text { IMPROVE-A }\end{array}$ & $\begin{array}{l}\text { Lodgepole pine, } \\
\text { black spruce, } \\
\text { ponderosa pine, } \\
\text { Douglas fir, } \\
\text { Average }\end{array}$ & $\begin{array}{l}25.1 \pm 51.6(\mathrm{~S}) \\
10.3 \pm 9.2(\mathrm{~S}) \\
36.6 \pm 72.6(\mathrm{~S}) \\
72.2 \pm 156.1(\mathrm{~S}) \\
32.3 \pm 119.2(\mathrm{~S})\end{array}$ & & $\begin{array}{l}\text { McMeeking et } \\
\text { al. (2009) }\end{array}$ \\
\hline $\begin{array}{l}\text { Siberian biomass } \\
\text { (combustion chamber) }\end{array}$ & $\begin{array}{l}\text { Thermal-optical, } \\
\text { NIOSH(TOT) }\end{array}$ & $\begin{array}{l}\text { Scots pine wood, } \\
\text { debris (needles, } \\
\text { branches, cones) }\end{array}$ & $\begin{array}{l}0.3-2.3(\mathrm{~F}) \\
126-181(\mathrm{~S}) \\
0.6(\mathrm{~F}) ; 35(\mathrm{~S})\end{array}$ & & $\begin{array}{l}\text { Popovicheva et } \\
\text { al. (2015) }\end{array}$ \\
\hline \multicolumn{6}{|c|}{ Agricultural fires } \\
\hline $\begin{array}{l}\text { ZOTTO, spring pollution events, } \\
28 \text { April } 2010 \text { and } 22-24 \text { April } 2011\end{array}$ & $\begin{array}{l}\text { Thermal-optical, } \\
\text { NIOSH(TOT) }\end{array}$ & $\begin{array}{l}\text { Crop residues and } \\
\text { steppe grasses }\end{array}$ & $12.7 \pm 2.7$ & $14.3 \pm 4.4$ & This study \\
\hline $\begin{array}{l}\text { ZOTTO, spring pollution events, } \\
\text { 20-22 April } 2008\end{array}$ & $\begin{array}{l}\text { PSAP }^{\mathrm{e}} \text {, light } \\
\text { absorption }\end{array}$ & $\begin{array}{l}\text { Crop residues and } \\
\text { steppe grasses }\end{array}$ & & 21.8 & Chi et al. (2013) \\
\hline $\begin{array}{l}\text { Agricultural plume, transport from southern Russia to } \\
\text { Italy (Mt. Cimone, ICO-OV - Italian Climate Observa- } \\
\text { tory "O. Vittori"), 1-4 May } 2009\end{array}$ & $\begin{array}{l}\text { MAAP } \text {, light } \\
\text { absorption }\end{array}$ & $\begin{array}{l}\text { Crop residues and } \\
\text { steppe grasses }\end{array}$ & & 29.8 & $\begin{array}{l}\text { Cristofanelli et } \\
\text { al. (2013) }\end{array}$ \\
\hline $\begin{array}{l}\text { Agricultural plume, transport from Kazakhstan steppe } \\
\text { to Alaskan Arctic, } 18 \text { April } 2008\end{array}$ & $\begin{array}{l}\mathrm{SP} 2^{\mathrm{C}} \text {, laser-induced } \\
\text { incandescence }\end{array}$ & $\begin{array}{l}\text { Crop residues and } \\
\text { steppe grasses }\end{array}$ & & $10 \pm 5$ & Warneke et al. (2009) \\
\hline $\begin{array}{l}\text { Agricultural plume, transport from Kazakhstan and } \\
\text { Siberia to Alaska, 12-13 April } 2008\end{array}$ & $\begin{array}{l}\mathrm{SP} 2^{\mathrm{C}} \text {, laser-induced } \\
\text { incandescence }\end{array}$ & $\begin{array}{l}\text { Crop residues and } \\
\text { steppe grasses }\end{array}$ & & $8.5 \pm 5.4(\mathrm{~F})$ & Kondo et al. (2011a) \\
\hline
\end{tabular}

large fraction of smoldering fires. The intermediate ratios of 12.9 and 18.2 obtained in spring (Fig. 4b) and fall (Fig. 4d) suggest that the air masses came to ZOTTO both from fossil fuel and biomass burning sources.

Unlike the $\triangle \mathrm{EC}-\triangle \mathrm{OC}$ relationship, the correlation between $\triangle \mathrm{EC}$ and $\Delta \mathrm{CO}$ is not as strong and varies greatly from season to season. The strongest correlation is found in the summer season $\left(R^{2}=0.85\right.$; Fig. $\left.5 \mathrm{c}\right)$, followed by the wintertime $\left(R^{2}=0.32\right.$; Fig. 5a), while no significant relationship between $\triangle \mathrm{EC}$ and $\triangle \mathrm{CO}$ was observed in spring and fall, with $R^{2}=0.02$ (Fig. 5b) and $R^{2}=0.02$ (Fig. 5d), respectively. The strength of the correlation between EC and CO strongly depends on the meteorological conditions. Wet deposition can affect aged EC (Matsui et al., 2011; Verma et al., 2011; Kanaya et al., 2016) but not CO, while CO can be removed from the atmosphere by oxidation with $\mathrm{OH}$ radicals (Hamilton et al., 2014). In addition, as noted above, CO can be produced from the oxidation of methane and non- 
Table 3. Continued.

\begin{tabular}{|c|c|c|c|c|c|}
\hline Location and study period & $\begin{array}{l}\text { Instrument, method, } \\
\text { protocol for EC }\end{array}$ & Fuel type & $\Delta \mathrm{OC} / \Delta \mathrm{EC}$ & $\begin{array}{l}\Delta \mathrm{EC} / \Delta \mathrm{CO} \\
\left(\mathrm{ng} \mathrm{m}^{-3} \mathrm{ppb}^{-1}\right)\end{array}$ & References \\
\hline $\begin{array}{l}\text { Agricultural plume at Indo-Gangetic } \\
\text { Plain, India }\left(\mathrm{PM}_{0.95}\right)\end{array}$ & $\begin{array}{l}\text { Thermal-optical, } \\
\text { NIOSH(TOT) }\end{array}$ & $\begin{array}{l}\text { Rice straw, } \\
\text { wheat straw }\end{array}$ & $\begin{array}{l}4.6 \pm 2.6 \\
2.7 \pm 1.0\end{array}$ & & Singh et al. (2016) \\
\hline $\begin{array}{l}\text { Post-harvest residues } \\
\text { (prescribed field burns) }\end{array}$ & $\begin{array}{l}\text { Thermal-optical } \\
\text { IMPROVE(TOR) }\end{array}$ & $\begin{array}{l}\text { Crop residues } \\
\text { (mainly wheat straw) }\end{array}$ & $\begin{array}{l}5.9 \pm 5.3(\mathrm{~F}) \\
12.3 \pm 2.0(\mathrm{~S})\end{array}$ & $\begin{array}{l}17.4 \pm 5.2(\mathrm{~F}) \\
11.8 \pm 2.4(\mathrm{~S})\end{array}$ & Pan et al. (2012) \\
\hline $\begin{array}{l}\text { Post-harvest residues } \\
\text { (prescribed field burns) }\end{array}$ & $\begin{array}{l}\text { microAeth. } \\
\text { AE5 } 1^{\mathrm{g}} \text {, light } \\
\text { absorption }\end{array}$ & $\begin{array}{l}\text { Wheat straw, } \\
\text { rice straw, } \\
\text { rapeseed residue }\end{array}$ & & $\begin{array}{l}14.4 \pm 6.4(\mathrm{M}) \\
9.3 \pm 1.1(\mathrm{~F}) \\
14.0 \pm 7.9(\mathrm{~F})\end{array}$ & Zhang et al. (2015) \\
\hline $\begin{array}{l}\text { Post-harvest residues } \\
\text { (prescribed field burns) }\end{array}$ & $\begin{array}{l}\text { Thermal-optical } \\
\text { IMPROVE(TOR) }\end{array}$ & $\begin{array}{l}\text { Corn stover, } \\
\text { wheat straw }\end{array}$ & $\begin{array}{l}11.1 \pm 5.8(\mathrm{~F}) \\
5.5 \pm 2.4(\mathrm{~F})\end{array}$ & $\begin{array}{l}8.3 \pm 6.7(\mathrm{~F}) \\
10.3 \pm 4.6(\mathrm{~F})\end{array}$ & Li et al. (2007) \\
\hline $\begin{array}{l}\text { Post-harvest residues } \\
\text { (prescribed field burns) }\end{array}$ & $\begin{array}{l}\text { Thermal-optical, } \\
\text { NIOSH(TOT) }\end{array}$ & $\begin{array}{l}\text { Meadow-grass straw, } \\
\text { wheat straw }\end{array}$ & $\begin{array}{l}8.2 \pm 2.5(\mathrm{~F}) \\
10.0 \pm 5.1(\mathrm{~F})\end{array}$ & $\begin{array}{l}4.4 \pm 3.5(\mathrm{~F}) \\
4.5 \pm 2.4(\mathrm{~F})\end{array}$ & $\begin{array}{l}\text { Dhammapala et } \\
\text { al. (2007a) }\end{array}$ \\
\hline $\begin{array}{l}\text { Post-harvest residues } \\
\text { (combustion hood, open burning) }\end{array}$ & $\begin{array}{l}\text { Thermal-optical } \\
\text { IMPROVE(TOR) }\end{array}$ & $\begin{array}{l}\text { Rice straw, } \\
\text { wheat straw, } \\
\text { barley straw }\end{array}$ & $\begin{array}{l}4.8-9.0^{\mathrm{h}} \\
12.2-16.9^{\mathrm{h}} \\
7.5-17.2^{\mathrm{h}}\end{array}$ & $\begin{array}{l}7.6-8.4^{\mathrm{h}} \\
13.1-14.3^{\mathrm{h}} \\
2.2-4.3^{\mathrm{h}}\end{array}$ & Hayashi et al. (2014) \\
\hline $\begin{array}{l}\text { Post-harvest residues } \\
\text { (burn chamber) }\end{array}$ & $\begin{array}{l}\text { Thermal-optical, } \\
\text { NIOSH(TOT) }\end{array}$ & $\begin{array}{l}\text { Meadow-grass straw, } \\
\text { wheat straw }\end{array}$ & $\begin{array}{l}10.9 \pm 1.5(\mathrm{~F}) \\
5.4 \pm 4.3(\mathrm{~F})\end{array}$ & & $\begin{array}{l}\text { Dhammapala et } \\
\text { al. (2007b) }\end{array}$ \\
\hline
\end{tabular}

methane hydrocarbons, which are mainly of biogenic origin and to lesser extent from anthropogenic sources (Gaubert et al., 2016). It therefore seems reasonable that the strength of the correlation between EC and $\mathrm{CO}$ depends on the season and the history of the air mass before arriving at ZOTTO. The strong correlation obtained in the summer season and the $\Delta \mathrm{EC} / \Delta \mathrm{CO}$ slope of $1.3 \pm 0.1 \mathrm{ng} \mathrm{m}^{-3} \mathrm{ppb}^{-1}$ suggest that both components were emitted into the atmosphere from the same nearby biomass burning sources. EC / $\mathrm{CO}$ emission ratios of $1.7 \pm 0.8$ and $3.4 \pm 1.6 \mathrm{ng} \mathrm{m}^{-3} \mathrm{ppb}^{-1}$ for smoldering and flaming combustion phases, respectively, were obtained during summer aircraft measurements in fresh boreal forest fire plumes (Kondo et al., 2011a) (Table 3). Therefore, our low overall summer $\Delta \mathrm{EC} / \Delta \mathrm{OC}$ ratio of $1.3 \mathrm{ng} \mathrm{m}^{-3} \mathrm{ppb}^{-1}$ suggests that the air masses arriving at ZOTTO were mainly influenced by smoldering fires. The fact that smoldering emissions tend to stay within the boundary layer because of the lower buoyancy produced by the less efficient smoldering combustion - whereas flaming emissions tend to rise several thousand metres - may also have contributed to the prevalence of smoldering emissions at ZOTTO.

The $\triangle \mathrm{EC} / \triangle \mathrm{CO}$ slope averaged over all winter polluted periods is $3.3 \pm 0.8 \mathrm{ng} \mathrm{m}^{-3} \mathrm{ppb}^{-1}$ (Fig. 5a). This is within the range of $1.4-5.4 \mathrm{ng} \mathrm{m}^{-3} \mathrm{ppb}^{-1}$ obtained in winter at the Hedo site (Okinawa Island, Japan) due to long-range transport of pollution plumes from East Asia (Verma et al., 2011), but on average it is lower than the values reported for industrial and urban regions of East Asia and North America (Table 3). Most likely in wintertime scavenging by ice crystal precipitation (Cozic et al., 2007) and dry deposition of EC has resulted in decreasing $\triangle \mathrm{EC} / \triangle \mathrm{CO}$ ratios during the air mass transport from the pollution sources to the ZOTTO site.

The lack of correlation $\left(R^{2} \sim 0.02-0.03\right)$ between $\Delta \mathrm{EC}$ and $\triangle \mathrm{CO}$ concentrations in spring (Fig. 5b) and in fall (Fig. 5d) is an indicator of the long-range transport of the polluted air masses from diverse sources. Since in the transi- tion seasons, the secondary CO sources and sinks are small, it is reasonable to assume that wet deposition of EC as well as variable source types are responsible for the poor relationship between EC and CO. In addition, $\mathrm{CO}$ from long-range transport from Europe may contribute a substantial fraction of CO at the ZOTTO site (Chi et al., 2013).

\subsection{Pollution episodes}

Next we consider in detail some specific pollution events that occurred during the sampling period from April 2010 to June 2014. We selected the most prominent events, where $\mathrm{PM}_{10}, \mathrm{EC}, \mathrm{CO}$, and OC concentrations exceeded their REBS background level simultaneously. These selected pollution periods and summary statistics for carbonaceous species, including their ratios, are shown in Table 4 . For all $\Delta X_{i} / \Delta X_{j}$ ratios presented in Table 4, each species concentration enhancement, $\Delta X_{i}$, was obtained as the difference between measured and REBS-derived concentrations. In addition, we also included the MLD, height above ground level (a.g.l.), and APT averaged along the air mass trajectories.

\subsubsection{Polluted winter air}

Figure 6 shows winter polluted 5-day air mass trajectories arriving at ZOTTO in the periods of 25-30 December 2010 (Fig. 5a, orange), 10-15 January 2011 (Fig. 5a, grey), and from 27 December 2011 to 9 January 2012 (Fig. 5b). It is seen that all trajectories passed over the southwestern and southern regions with densely populated industrialised areas and therefore air masses moving across this area are likely to have accumulated anthropogenic emissions. During these periods, the trajectory heights (Fig. 5c, d) were less than or comparable to the mixed layer depth (Table 4), indicating that the polluted air masses were trapped under a very low inversion layer. In addition, the precipitation rates along the trajectories were moderate (Table 4). These meteorolog- 

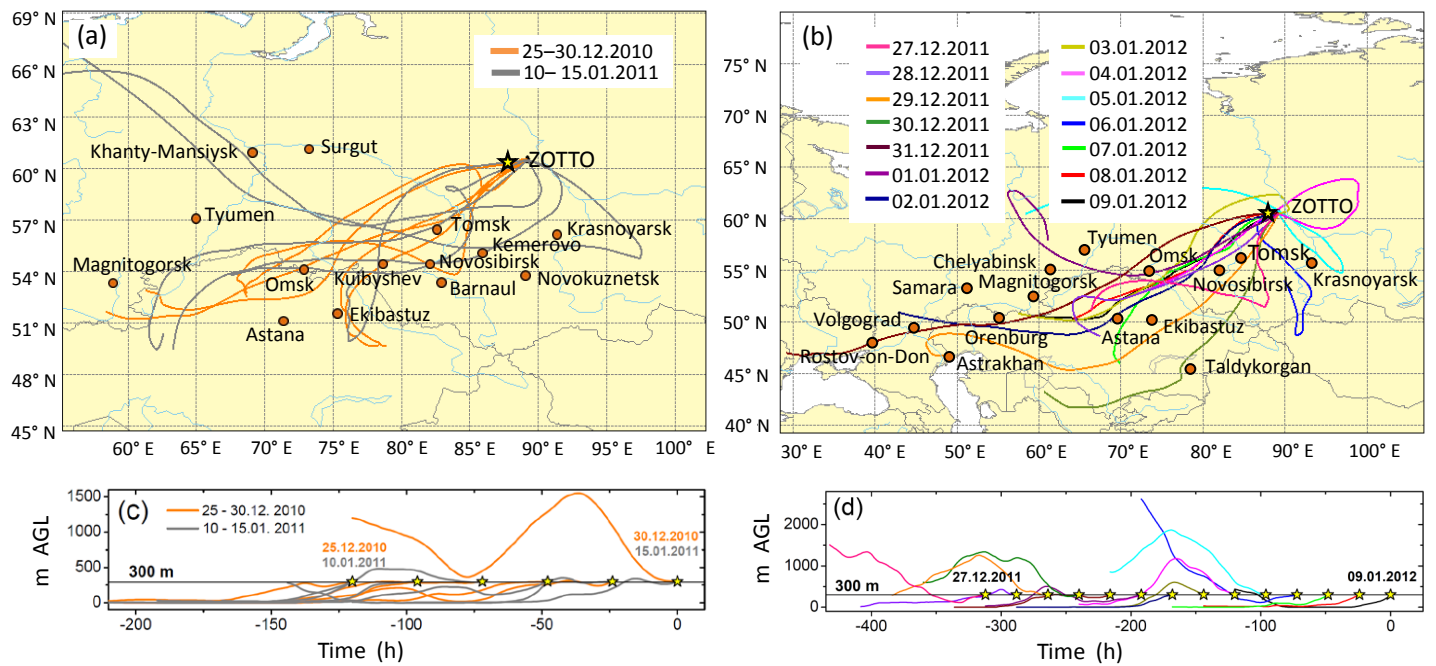

Figure 6. Figure shows $120 \mathrm{~h}$ HYSPLIT backward air mass trajectories with $24 \mathrm{~h}$ intervals during winter pollution events at ZOTTO at $300 \mathrm{~m}$ observed from 25 to 30 December 2010 (a, orange), 10 to 15 January 2011 (a, grey), and 27 December 2011 to 9 January 2012 (b) and trajectory height above ground level (a.g.l.) (c, d). Stars and dates show the arrival time of the air mass.

ical conditions contributed to the relatively high $\mathrm{CO}, \mathrm{PM}_{10}$, and carbonaceous species concentrations observed during the winter pollution periods. As a result, the overall $\Delta \mathrm{OC} / \Delta \mathrm{EC}$ slope for the winter pollution periods is $3.9 \pm 0.6\left(R^{2}=\right.$ 0.75 ) (Table 3). This value is consistent with emission ratios found in urban areas, and represents a mixture between aged regional haze aerosols with OC / EC ranging from 3 to 7 and local emissions with a ratio of about 1.4 (Andreae et al., 2008b; Meng et al., 2007; Li et al., 2012; Cheng et al., 2011; Pan et al., 2012) (Table 3).

The $\triangle \mathrm{EC} / \triangle \mathrm{CO}$ slope for the winter pollution episodes is $5.8 \pm 0.7 \mathrm{ng} \mathrm{m}^{-3} \mathrm{ppb}^{-1}\left(R^{2}=0.85\right)$ (Table 3). This ratio is consistent with a fossil-fuel-dominated carbonaceous aerosol, as is typically observed at urban sites, e.g. $5.7 \pm 0.9$ (Tokyo; Kondo et al., 2006), $5.4 \pm 0.4$ (Guangzhou; Verma et al., 2010), $5.8 \pm 1.0$ (Houston, Dallas; Spackman et al., 2008), and 3.5-5.8 (Beijing; Han et al., 2009), and somewhat lower than values found for periods when urban air masses are polluted by diesel traffic emissions: $7.9 \pm 0.2$ (Guangzhou; Andreae et al., 2008b), $7.7 \pm 0.2$ (Beijing, fall; Wang et al., 2011), and $8.4 \pm 0.4$ (North China Plain; Wang et al., 2011) (Table 3).

In winter, the $\triangle \mathrm{TCM}$ fraction in the $\triangle \mathrm{PM}$ varies from 0.17 to 0.37 (Table 2), which implies that the dominant $\mathrm{PM}_{10}$ components are inorganic compounds. Our independent measurements performed from 15 to 25 December 2011 showed that the main inorganic anthropogenic ions are sulfates $(\sim 32 \%)$, nitrates $(\sim 6 \%)$, ammonium $(\sim 5 \%)$, and minor components such as sodium $(\sim 1 \%)$ and potassium $(\sim 1 \%)$. The contribution of other ions is less than $1 \%$ (Mikhailov et al., 2015b).

\subsubsection{Polluted summer air}

Previous studies based on CO measurements during 2007 and 2008 (Vasileva et al., 2011) and those complemented by an analysis of aerosol properties (concentration, absorption, and scattering coefficients) from 2006 to 2012 (Chi et al., 2013) indicate that in the summer season pollution events are mainly associated with biomass burning emissions. Our results are in agreement with these earlier studies. Table 4 shows that within the selected summer periods, $\mathrm{CO}, \mathrm{PM}_{10}$, and carbonaceous species concentrations are extremely high, exceeding their background values by a factor of 20 or even more (Fig. 3) and suggesting therefore that the biomass burning events were close to the ZOTTO site. As an example, Fig. 7 shows fires detected by MODIS in June-July 2012 and trajectories that passed over them. It is evident that the fires were very close to our site, resulting in strong correlations between $\triangle \mathrm{EC}, \triangle \mathrm{OC}$, and $\triangle \mathrm{CO}\left(R^{2}>0.9\right)$ (Fig. 8). The $\triangle \mathrm{OC} / \triangle \mathrm{EC}$ and $\triangle \mathrm{EC} / \triangle \mathrm{CO}$ ratios from the fire pollution episodes are $26.2 \pm 0.1$ and $1.4 \pm 0.1 \mathrm{ng} \mathrm{m}^{-3} \mathrm{ppb}^{-1}$, respectively (Table 3). As discussed in Sect. 4.5 and shown in Table 3 , these values are in the range of emission ratios found in boreal forest fires dominated by smoldering. In addition, the $\Delta \mathrm{TCM} / \triangle \mathrm{PM}$ ratio was close to 1 , indicating that carbonaceous material was the dominant component in $\mathrm{PM}_{10}$. The $\Delta \mathrm{WSOC} / \triangle \mathrm{OC}$ ratio ranged from 0.47 to 0.68 and did not correlate with meteorological conditions (Table 3), probably due to the short-distance transport of the pollution plumes.

\subsubsection{Polluted air in the transition seasons}

In the spring season, strongly elevated concentrations of $\mathrm{CO}, \mathrm{PM}_{10}$, and carbonaceous species were observed on 

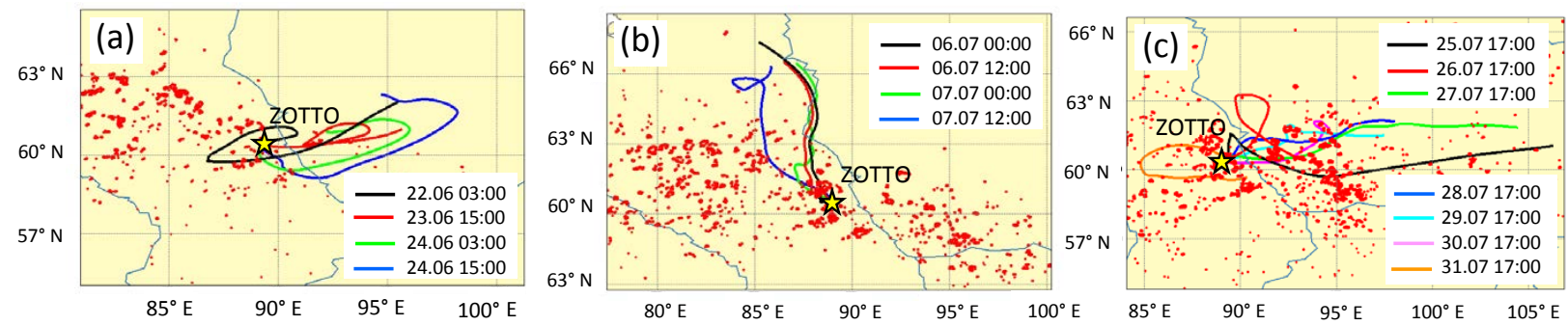

Figure 7. Figure shows $72 \mathrm{~h}$ HYSPLIT air mass trajectories during summer biomass burning events at ZOTTO at $300 \mathrm{~m}$ : 22 to 24 June 2012 (a), 6 to 7 July 2012 (b), and 25 to 31 July 2012 (c). Red dots indicate the fire locations.

28 April 2010 (Table 4). Figure 9a shows large-scale fires as observed by the MODIS satellite. In this period, the fires were mainly located in the middle belt of European Russia and in the area covering the south and southwest of Siberia and northern Kazakhstan (Fig. 7a). The HYSPLIT 4-day trajectories show that the air masses that arrived at ZOTTO on 28 April 2010 had passed over these fire zones. In particular, the low-altitude air masses that arrived at ZOTTO from 18:00 to 24:00 on 28 April had passed over fires located in southern Siberia (Novosibirsk region), whereas the high-altitude airflows that arrived between 00:00 and 16:00 on 28 April 2010 had travelled over the fires in the European part of Russia and southwestern Siberia (Tyumen region) (Fig. 9a, c). As a result, the $\mathrm{CO}, \mathrm{PM}_{10}, \mathrm{OC}$, and $\mathrm{EC}$ concentrations reached $261 \mathrm{ppb}, 54 \mu \mathrm{g} \mathrm{m}^{-3}, 18.9 \mu \mathrm{g} \mathrm{m}^{-3}$, and $1.5 \mu \mathrm{g} \mathrm{m}^{-3}$ (Table 4), exceeding their REBS background values by factors of 1.7, 10,13 , and 15 , respectively. That was despite the fact that the median trajectory height was well above the mixed layer depth $(300 \mathrm{~m}$ vs. $74 \mathrm{~m})$ and that precipitation $(4.2 \mathrm{~mm})$ could have removed aerosol species (Table 4). It is worth noting in this regard that chemical compounds released by large fires may be injected into the atmosphere up to altitudes of several kilometres, reaching the free atmosphere and even the lower stratosphere (Liousse et al., 1996; Andreae et al., 2001, 2004; Trentmann et al., 2006; Rosenfeld et al., 2007).

The large-scale biomass burning that occurs annually in April-May in southern Russia, including Siberia and northern Kazakhstan, is caused by agricultural fires started by farmers clearing the fields. Agricultural prescribed burning in Russia is estimated to total 30 million ha annually, of which about 5 million ha is stubble burning (wheat, rye, barley, and oat straw), and 25 million ha is pastures and hayfields (Shvidenko et al., 1995). These burns often escape and cause forest wildfires. The air masses impacted by these fires can be transported over long distances. For example, Siberian and Kazakhstan agricultural emission plumes were sampled by flights over northern Alaska (Warneke et al., 2009; Kondo et al., 2011a) and the Arctic (Matsui et al., 2011).

Our $\triangle \mathrm{OC} / \triangle \mathrm{EC}$ ratio obtained for agricultural plumes during pollution episodes is $12.7 \pm 2.7$, which is slightly higher than values reported for prescribed fires during field and chamber experiments (Table 3 ). The reason could be chemical and physical ageing processes during long-range transport of polluted air masses from the sources to ZOTTO. Adsorption, condensation, and cloud processing of semivolatile organic compounds tend to increase the OC abundance in the particulate matter (Kanakidou et al., 2005; Hallquist et al., 2009; Sakamoto et al., 2016; Konovalov et al., 2015, 2017). In particular, Chi et al. (2013) showed that during long-range transport of agricultural plumes the particles grew from 40 to $100 \mathrm{~nm}$ within the first $30 \mathrm{~h}$, with a growth rate of about $2 \mathrm{~nm} \mathrm{~h}^{-1}$ due to condensation and coagulation.

The $\triangle \mathrm{EC} / \triangle \mathrm{CO}$ ratio for the selected agricultural burning episode is $14.3 \pm 4.4 \mathrm{ng} \mathrm{m}^{-3} \mathrm{ppb}^{-1}$, comparable to values reported for prescribed field fires by Pan et al. (2012), Zhang et al. (2015), and Li et al. (2007) but higher than those derived during chamber combustion experiments (Dhammapala et al., 2007b; Hayashi et al., 2014) (Table 3). It should be noted that in combustion experiments the emission factor for different carbon species strongly depends on the type of residue combusted, initial moisture content, burning phase, and analytical instrument used for EC analysis. As a result, different studies yield a wide range of OC / EC and EC / CO ratios, as shown in Table 3 (under "Agricultural fires"). In addition, the long-range transport of agricultural plumes can change these ratios significantly due to aerosol aging and wet scavenging.

As a case in point, the previous long-distance observations of spring agricultural plumes from Siberia and Kazakhstan, sampled by flights from northern Alaska (Fairbanks), reported $\Delta \mathrm{EC} / \Delta \mathrm{CO}$ values of $10 \pm 5$ (Warneke et al., 2009) and $8.5 \pm 5.4 \mathrm{ng} \mathrm{m}^{-3} \mathrm{ppb}^{-1}$ (Kondo et al., 2011a) (Table 3). These ratios are almost a factor of 1.5 lower than our ratio of $14.3 \pm 4.4 \mathrm{ng} \mathrm{m}^{-3} \mathrm{ppb}^{-1}$, although the EC values from the single-particle soot photometer (SP2) and the Sunset (TOT) instruments are directly comparable (Kondo et al., 2011b); for example, Laborde et al. (2013) reported a slope of 1.05 between the two methods. It is reasonable therefore to explain this difference with different air mass history (i.e. wind patterns, boundary layer dynamics, and precipitation), while of course differences in combustion conditions cannot be excluded either. The distance between the agricultural fires and the sampling areas is almost 5 times greater for Fairbanks than for ZOTTO, and precipitation could have substantially 


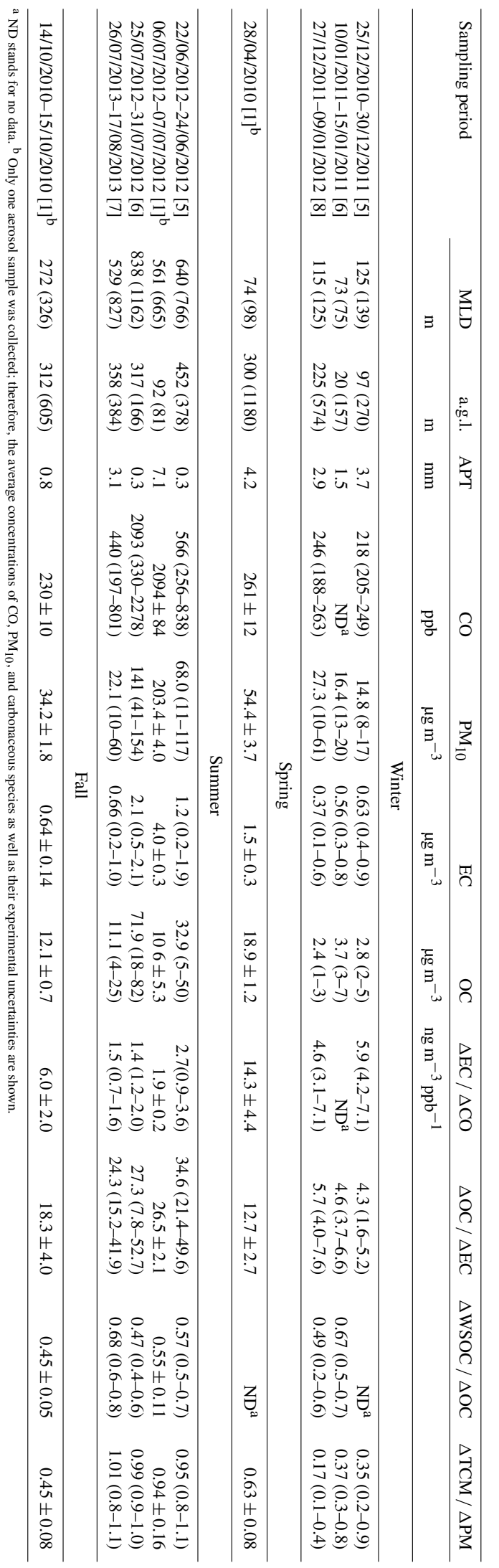

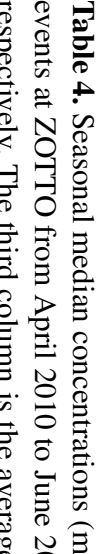

o

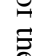

훌 훌

กี $\Rightarrow$

苍

苍。

융.

을

응.

क

훙

(⿻日禸

궁

응

जे

\%

ㅋ.ㅇ. 总.

ஓ

झ 节

융ำ

\& $\mathbb{E}$

픙용

핑ㅁㅇ

กิำ

$\triangleright \forall \triangleright$

丸气 苛

ڤํ.?

品

옹 decreased the EC concentration at Fairbanks as compared to ZOTTO.

In turn, our ratio is almost 2 times lower than the values of $30 \mathrm{ng} \mathrm{m}^{-3} \mathrm{ppb}^{-1}$ measured by Cristofanelli et al. (2013) at the remote Mt. Cimone (Italy) and $22 \mathrm{ng} \mathrm{m}^{-3} \mathrm{ppb}^{-1} \mathrm{ob}-$ tained at the ZOTTO site by Chi et al. (2013) (Table 3). Besides differences in the air mass history, in this case the observed disagreement could have been caused by the different methods used for EC analysis. The MAAP (multi-angle absorption photometer) and PSAP instruments used by Cristofanelli et al. (2013) and Chi et al. (2013), respectively, utilise light attenuation on filters. Both methods tend to overestimate the mass concentration of EC because of the lens effects of organic matter and the light-absorbing brown carbon substances deposited on the filter matrix (Andreae and Gelencsér, 2006; Bond et al., 2006; Reisinger et al., 2008; Lack and Cappa, 2010). In contrast, the thermo-optical NIOSH 5040 method (used in this study) tends to underestimate EC, especially for biomass aerosols, due to its potential evaporation in the $\mathrm{He}$ atmosphere at temperatures below $750^{\circ} \mathrm{C}$ and/or the catalytic effects of potassium salts (Chow et al., 2001). For example, an intercomparison of EC measurements in central eastern China indicated that the EC mass measured by MAAP was systematically $45-54 \%$ higher than the EC mass determined by the thermal-optical transmittance method (Kanaya et al., 2008).

Figure 10 shows the scatter plot between PSAP-derived $\mathrm{BC}_{\mathrm{e}}$ and thermal-optical EC obtained in this study during 19 April 2010-15 May 2012. The $\mathrm{BC}_{\mathrm{e}}$ concentration was calculated from Eq. (1) with the commonly used value of $\alpha_{\mathrm{abs}}$ of $10 \mathrm{~m}^{2} \mathrm{~g}^{-1}$. A good correlation between EC and $\mathrm{BC}_{\mathrm{e}}$ for the entire period with $R^{2}=0.90$ is observed, with a $\mathrm{BC}_{\mathrm{e}} / \mathrm{EC}$ slope of $1.67 \pm 0.05$. Thus, our $\Delta \mathrm{EC} / \Delta \mathrm{CO}$ ratio of $14.3 \pm 4.4 \mathrm{ng} \mathrm{m}^{-3} \mathrm{ppb}^{-1}$ obtained for agricultural fires (Table 4) can be converted to a $\Delta \mathrm{BC}_{\mathrm{e}} / \Delta \mathrm{CO}$ ratio of $2 \pm 7.3 \mathrm{ng} \mathrm{m}^{-3} \mathrm{ppb}^{-1}$. This value is within the range of 22 and $30 \mathrm{ng} \mathrm{m}^{-3} \mathrm{ppb}^{-1}$ reported by Chi et al. (2013) and Cristofanelli et al. (2013), respectively, using filter-based light absorption techniques (Table 3).

In the fall season, elevated concentrations of $\mathrm{CO}, \mathrm{PM}_{10}$, and carbonaceous species were observed during 14-15 October 2010. Figure $9 \mathrm{~b}$ shows that air masses arriving at ZOTTO were impacted by large-scale fires and anthropogenic emissions from industrialised urban sites. As in the case of the spring pollution episodes, the observed fires are caused by agricultural burning of crop, pasture, and hayfield residues. Figure 9d shows that about half of the 4-day HYSPLIT trajectories stay well below $300 \mathrm{~m}$, that is, the air masses moved mainly within the boundary layer (median MLD: $272 \mathrm{~m}$; interquartile range: $326 \mathrm{~m}$ ), implying that dilution for these pollution plumes was modest. In addition, the precipitation amounts along the trajectories were small (Table 4). For the selected period, the $\Delta \mathrm{OC} / \Delta \mathrm{EC}$ ratio is $18.3 \pm 4.0$, falling between the values obtained during summer burning (2435 ) and winter pollutions (4.3-5.7) episodes and indicating 

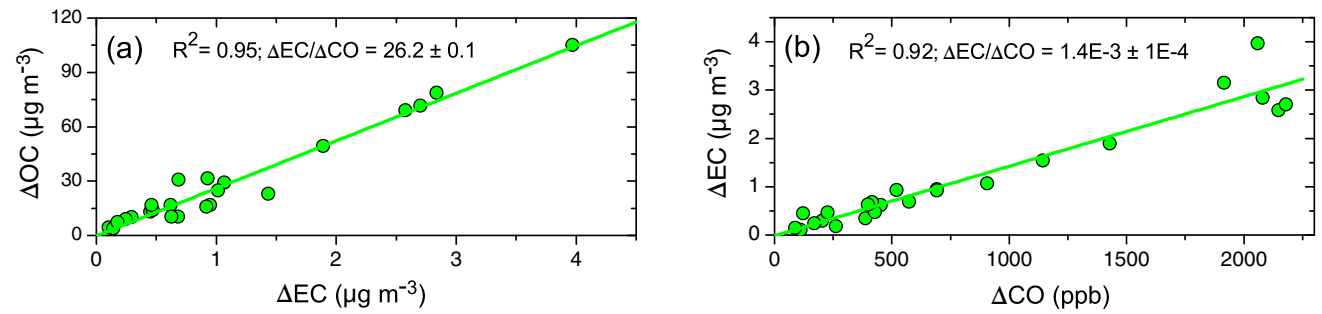

Figure 8. Scatter plot and linear regression of $\triangle \mathrm{EC}-\triangle \mathrm{OC}$ (a) and $\Delta \mathrm{CO}-\Delta \mathrm{EC}$ (b) during biomass burning episodes in the summer season (Table 2). The $\Delta \mathrm{EC} / \Delta \mathrm{CO}$ slope is in $\mu \mathrm{g} \mathrm{m}^{-3} \mathrm{ppb}^{-1}$.
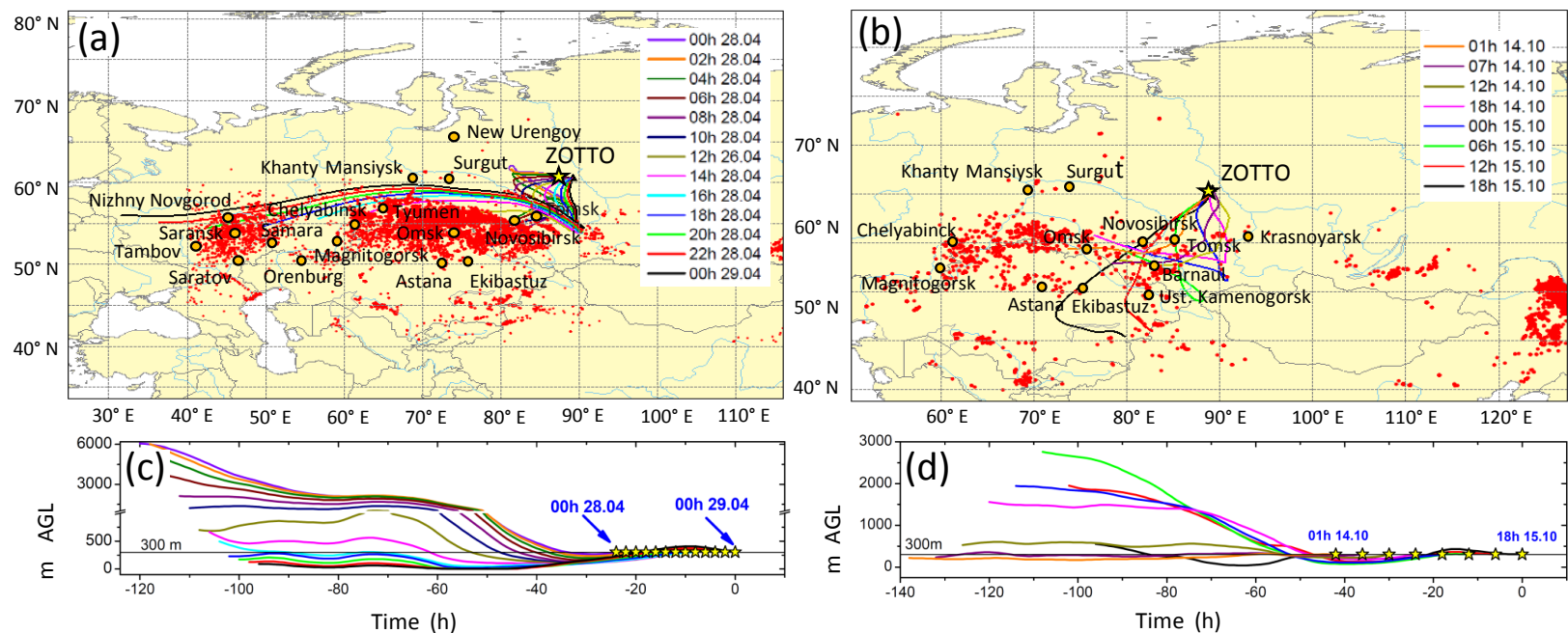

Figure 9. Figure shows 96 h HYSPLIT air mass trajectories during spring pollution events at ZOTTO at $300 \mathrm{~m}$ on 28 April 2011 (a) and 14 to 15 October 2010 (b) and their height above ground level (a.g.l.) (c and d, respectively). Red dots indicate the fire locations (a, b). Stars and dates show the arrival time of air mass with $2 \mathrm{~h}(\mathbf{a}, \mathbf{c})$ and $6 \mathrm{~h}(\mathbf{b}, \mathbf{d})$ intervals, respectively.

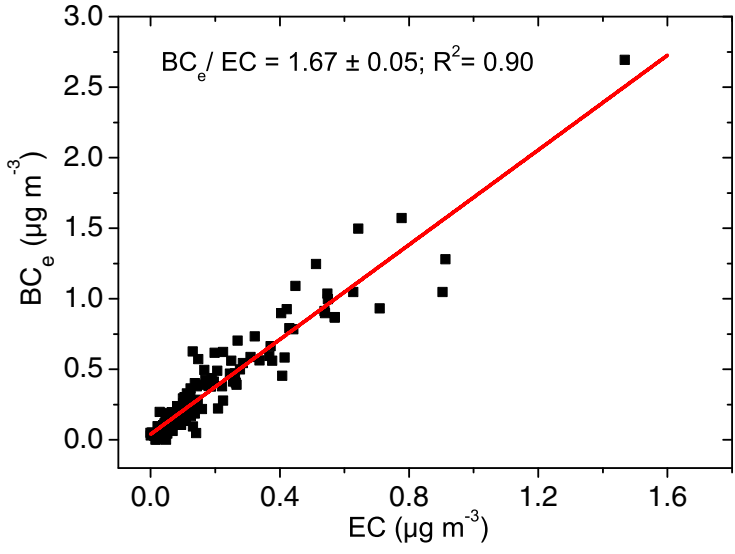

Figure 10. Scatter plot and linear regression between thermal-optical EC and light absorption $\mathrm{BC}_{\mathrm{e}}$ observed during 19 April 2010-15 May 2012. The $\mathrm{BC}_{\mathrm{e}} / \mathrm{EC}$ slope is $1.67 \pm 0.05$ with $R^{2}=0.90$. that the polluted air masses were enriched by organic species from biomass burning (Table 4) but with more of a smoldering component than in the spring episode. In contrast, the $\triangle \mathrm{TCM} / \triangle \mathrm{PM}(=0.45)$ was lower than that in spring and summer (Table 4), suggesting that there was a strong contribution of inorganic compounds from urban emissions to the $\mathrm{PM}_{10}$. The $\triangle \mathrm{EC} / \triangle \mathrm{CO}$ ratio for the selected period was $6.0 \pm 2.0 \mathrm{ng} \mathrm{m}^{-3} \mathrm{ppb}^{-1}$, which lies in the middle of the range of values from the other seasons and therefore also suggests a mixture of sources (Tables 3 and 4), including a significant impact of anthropogenic emissions on the air mass composition arriving at ZOTTO during the selected period.

Summing up the analysis of seasonal and episodic pollution presented above, we can conclude the following. In the winter season pollution originates mainly from the big cities to the south and southwest of the ZOTTO site. In summertime, strong Siberian forest fires are responsible for elevated concentrations of $\mathrm{CO}, \mathrm{PM}$, and carbonaceous species, and in the spring and fall seasons both agricultural burning and anthropogenic emissions contribute to the observed elevated concentrations at ZOTTO. In general, our 


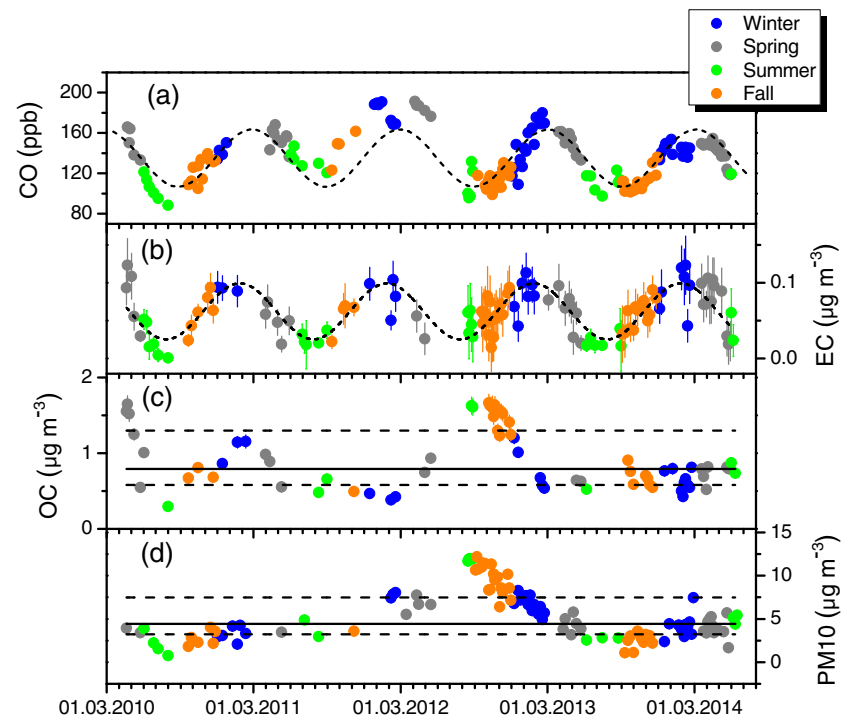

Figure 11. Time series of CO (a), EC (b), OC (c), and $\mathrm{PM}_{10}$ (d) background concentrations for $300 \mathrm{~m}$ at ZOTTO. Fit lines: (a, b) sine fit with time period of $365 \pm 4$ days and coefficient of determination, with $R^{2}=0.60$ and 0.58 , respectively; $(\mathbf{c}, \mathbf{d})$ median black solid; 75 and 25 th percentiles - dashed line. Different colours represent the different seasons.

results are consistent with the earlier analysis of the pollution sources conducted for the ZOTTO station during the 2007 and 2008 warm seasons (Vasileva et al., 2011), between September 2006 and December 2011 (Chi et al., 2013), and from September 2006 to December 2011 (Heintzenberg et al., 2013).

\subsection{Characterisation of background air}

Figure 11 shows the time series of $\mathrm{CO}, \mathrm{EC}, \mathrm{OC}$, and $\mathrm{PM}_{10}$ background concentrations, which were obtained based on the REBS algorithm. The median background concentrations (25-75th quartiles) across the entire study period for EC, OC, and $\mathrm{PM}_{10}$ were $0.06(0.04-0.08) \mu \mathrm{g} \mathrm{m}^{-3}, 0.79$ $(0.58-1.29) \mu \mathrm{g} \mathrm{m}^{-3}$, and $4.4(3.2-7.5) \mu \mathrm{g} \mathrm{m}^{-3}$, respectively (Fig. 11c, d).

Both CO (Fig. 11a) and EC (Fig. 11b) concentrations show synchronous seasonal variations with a clear annual period of $365 \pm 4$ days (sine fit). The maximum concentrations of $\mathrm{CO}$ and EC fall in the winter at $\sim 160 \mathrm{ppb}$ and $\sim 0.1 \mu \mathrm{g} \mathrm{m}^{-3}$, respectively, while the minimal values of $\sim 100 \mathrm{ppb}$ and $\sim 0.03 \mu \mathrm{g} \mathrm{m}^{-3}$ are observed in the summer season. The Pearson correlation coefficient between background $\mathrm{EC}$ and $\mathrm{CO}$ concentrations over all seasons is 0.59 , which is a fairly close relationship considering that both species come to ZOTTO from remote combustion sources and that atmospheric processes exert different influences on the two species, as discussed above.
In contrast, the OC (Fig. 11c) and $\mathrm{PM}_{10}$ (Fig. 11d) concentrations do not exhibit clearly pronounced annual variations. Such a lack of seasonality of the total aerosol concentration ha already been noted by Chi et al. (2013) based on measurements of aerosol volume concentration and scattering coefficients. This is likely the result of a combination of effects, where the regional production of biogenic SOA from VOCs in summer is balanced by higher inputs of pollution aerosols in winter. As noted above, aerosol aging and precipitation could further modify the proportion between different species. It is known that aged organic species and watersoluble inorganic compounds are removed from the atmosphere by wet deposition more efficiently than EC (Cerqueira et al., 2010; Witkowska et al., 2016). In addition, during the transition from winter to summer, differential scavenging of the aerosol species can occur in mixed-phase clouds due to the Wegener-Bergeron-Findeisen effect (Wegener, 1911; Bergeron, 1935; Findeisen, 1938). In this type of clouds, the scavenging efficiency of EC decreased by more than a factor of 5 (Cozic et al., 2007; Qi et al., 2017).

\subsubsection{Near-pristine air}

Over the entire measurement period, the cleanest air masses were observed in summertime, as long as biomass burning pollution did not affect the site. We selected three clean periods based on the selection criterion that $\mathrm{EC}$ concentrations had to be below the detection limit of $0.02 \pm 0.01 \mu \mathrm{gC} \mathrm{m} \mathrm{C}^{-3}$. Table 5 summarises the dates and chemical species concentrations obtained during these time periods. The lowest concentrations were observed from 7 July to 1 August 2010. For this period, the EC concentration was below the detection limit and the $\mathrm{CO}$ mixing ratio was as low as $93 \pm 11 \mathrm{ppb}$ (Table 5). Backward trajectories computed for this time period together with fire maps (Fig. 12a, b) show that the trajectories either did not pass through the fires (panels a2, a6, a8, a9, a10) or just barely touched them (Fig. 12a; panels a3-a5, a7, a11-a14). Given the low CO concentration, a measurable pollution input from the fires is not to be expected. In addition, any biomass burning aerosol that may have been transported in the boundary layer (Table 5, columns 1 and 2) could have been effectively removed via precipitation $(\mathrm{APT}=7.3 \mathrm{~mm})$ (Kanaya et al., 2016; Ohata et al., 2016). Figure $12 \mathrm{c}$ shows that precipitation with different intensity occurred along the air mass trajectories before they reached the measuring site. As a result the $\mathrm{PM}_{10}$ and $\mathrm{OC}$ concentrations were as low as $0.77 \pm 0.09$ and $0.29 \pm 0.02 \mu \mathrm{g} \mathrm{m}^{-3}$, respectively. The TCM / PM ratio was the highest among the clean periods (Table 5), suggesting that biogenic SOA was the main component in the particulate matter.

For the other relatively clean periods, i.e. 6-10 July 2011 and 15-27 June 2013, the $\mathrm{PM}_{10}$ and carbonaceous species concentrations were much higher than those presented above (Table 5). Most likely, the air masses arriving at ZOTTO during these time intervals were partly influenced by remote pol- 
Table 5. Average CO, $\mathrm{PM}_{10}$, and carbonaceous species concentrations ( $\pm \mathrm{SD}$ ) together with WSOC / OC and TCM / PM ratios obtained during the cleanest periods in the growing season. MLD and $\mathrm{m}$ a.g.l. are median and 25-75th quartiles of the mixed layer depth and air mass trajectory height above ground level, respectively.

\begin{tabular}{|c|c|c|c|c|c|c|c|c|c|}
\hline \multirow[t]{2}{*}{ Sampling period } & MLD & a.g.l. & $\mathrm{CO}$ & $\mathrm{PM}_{10}$ & EC & $\mathrm{OC}$ & WSOC & WSOC / OC & $\mathrm{TCM} / \mathrm{PM}$ \\
\hline & $\mathrm{m}$ & $\mathrm{m}$ & $\mathrm{ppb}$ & $\mu \mathrm{g} \mathrm{m}^{-3}$ & $\mu \mathrm{g} \mathrm{m}^{-3}$ & $\mu \mathrm{g} \mathrm{m}^{-3}$ & $\mu \mathrm{g} \mathrm{m}^{-3}$ & & \\
\hline $07.07 .2010-01.08 .2010$ & $526(275-831)$ & $290(201-402)$ & $93 \pm 11$ & $0.77 \pm 0.09$ & $<0.002$ & $0.29 \pm 0.02$ & $0.16 \pm 0.02$ & $0.53 \pm 0.07$ & $0.68 \pm 0.10$ \\
\hline 06.07.2011-10.07.2011 & 747 (367-119) & $122(24-241)$ & $\mathrm{ND}^{*}$ & $8.7 \pm 0.5$ & $0.018 \pm 0.031$ & $1.14 \pm 0.05$ & $0.61 \pm 0.08$ & $0.54 \pm 0.08$ & $0.24 \pm 0.02$ \\
\hline 15.06.2013-27.06.2013 & 415 (208-736) & $267(179-337)$ & $119 \pm 14$ & $5.3 \pm 0.2$ & $0.018 \pm 0.010$ & $1.46 \pm 0.08$ & $1.22 \pm 0.14$ & $0.84 \pm 0.11$ & $0.50 \pm 0.03$ \\
\hline
\end{tabular}

* ND stands for no data.
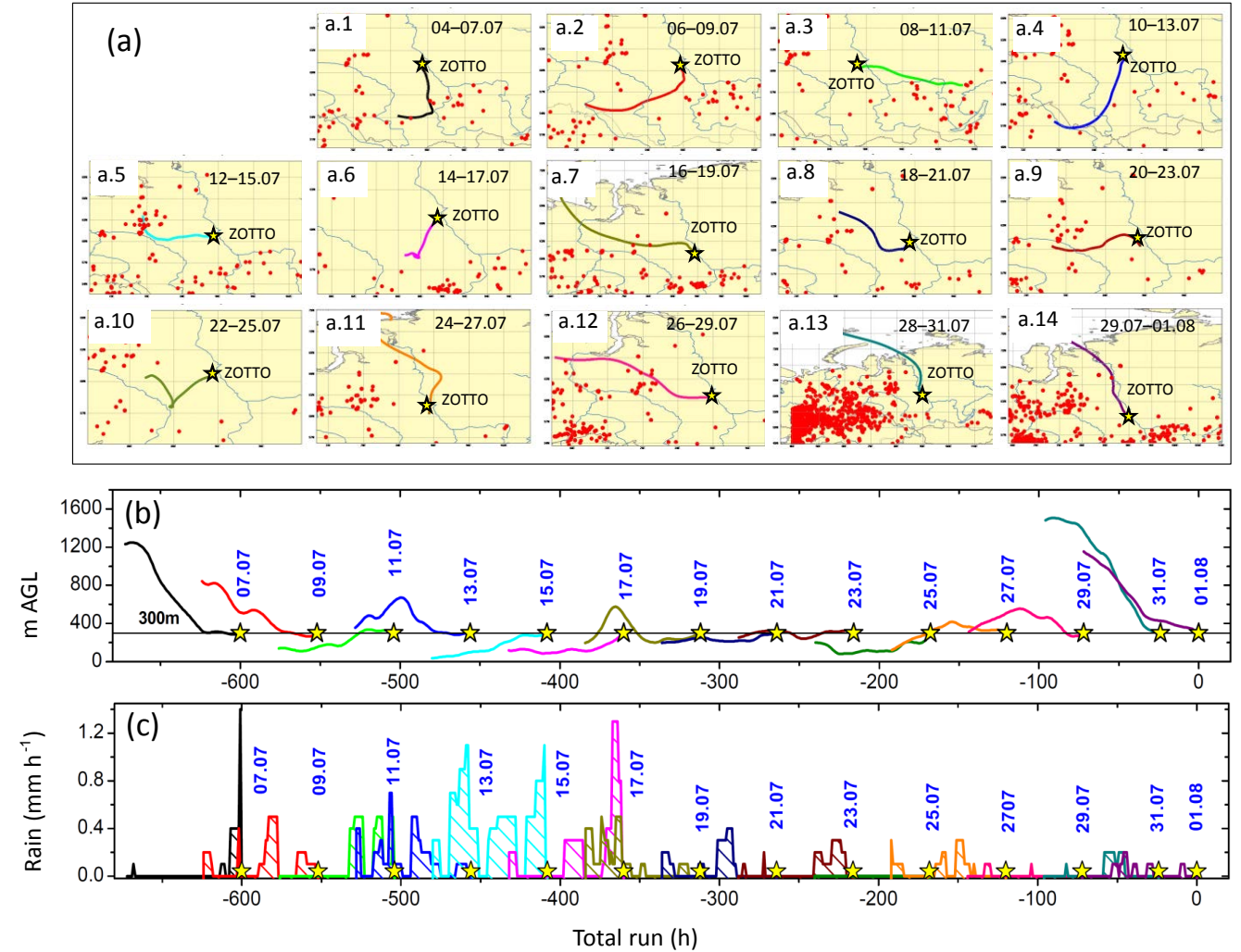

Figure 12. Panel (a): $72 \mathrm{~h}$ HYSPLIT air mass trajectories with $48 \mathrm{~h}$ intervals during background periods at ZOTTO at $300 \mathrm{~m}$ from 7 July to 1 August 2010; red dots indicate the fire locations within a $72 \mathrm{~h}$ period. Panel (b): their height above ground level (a.g.l.) and (c) precipitation rate along the air mass trajectories. Stars and dates show the arrival time of the air masses $(\mathbf{b}, \mathbf{c})$.

lution sources. Figure 13a, b show that the location of some hot spots (bold red circles) coincides with gas and oil field production, suggesting that these hot spots represent gas flaring (Elvidge et al., 2011; Anejionu et al., 2015), which is a significant source of EC and other carbonaceous species (Stohl et al., 2013). Therefore, the air masses coming over the land surface from the northwest (Fig. 13c, d) could have accumulated gas flaring products emitted from oil production sites in the West Siberia Basin. In addition, the southeastern air masses arriving at ZOTTO on 19 June 2013 (Fig. 13b) passed over forest fires and most likely were also enriched with biomass combustion products. On the other hand, for some time intervals, precipitation along the air mass trajec- tories was light and scattered (Fig. 13e, f), indicating that aerosol scavenging by precipitation was modest. Thus, during otherwise clean periods, the presence of remote pollution sources (gas flaring) as well as different meteorological conditions (precipitation) could lead to very different $\mathrm{PM}_{10}$ ( 0.77 vs. 8.7 and $5.3 \mu \mathrm{g} \mathrm{m}^{-3}$ ) and $\mathrm{OC}(0.29$ vs. 1.14 and $1.46 \mu \mathrm{g} \mathrm{m}^{-3}$ ) concentrations (Table 5).

In the growing season, forested boreal regions emit biogenic volatile organic compounds (BVOCs) (isoprene, terpenes and sesquiterpenes) into the atmosphere (Kourtchev et al., 2005; Ehn et al., 2012; Noe et al., 2012; Ebben et al., 2011; Vestenius et al., 2014), and their oxidation products contribute to SOA formation or condense onto already 

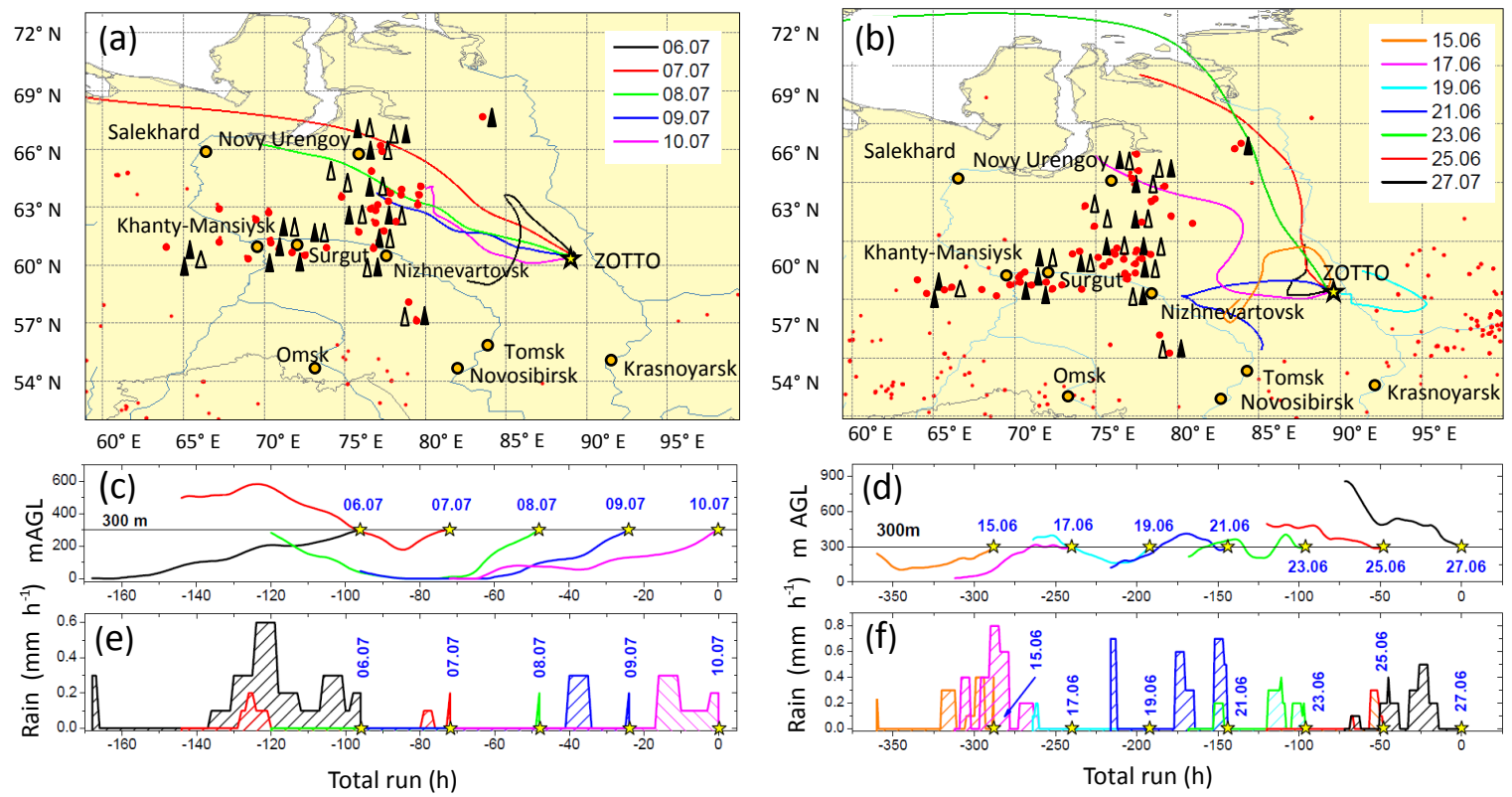

Figure 13. Figure shows $72 \mathrm{~h}$ HYSPLIT air mass trajectories during clean periods at ZOTTO at $300 \mathrm{~m}$ from 6 to $10 \mathrm{July} 2011$ with $24 \mathrm{~h}$ intervals (a) and from 15 to 27 July 2013 with $48 \mathrm{~h}$ intervals (b). Bold red dots indicate the hot spots, which are most likely associated with gas flaring; open and solid triangles stand for gas and oil production fields, respectively; panels (b, d) show trajectory heights above ground level (a.g.l.) and panels $(\mathbf{c}, \mathbf{f})$ rain rate $\left(\mathrm{mm} \mathrm{h}^{-1}\right)$ along the air mass trajectories. Stars and dates show the arrival times of air masses $(\mathbf{c}, \mathbf{d}, \mathbf{e}$, f).

formed particles during transport, increasing aerosol sizes and mass (Tunved et al., 2006; Hallquist et al., 2009; Chi et al., 2013; Liao et al., 2014). Since the emission of the organic particle precursors depends on air temperature (Isidorov et al., 1985; Lappalainen et al., 2009), the SOA mass concentration also positively correlates with temperature (Leaitch et al., 2011; Corrigan et al., 2013; Liao et al., 2014). Earlier measurements conducted at ZOTTO in 2009 during a pristine summer period had shown a clear temperature dependence with increasing number concentration and particle size for higher air temperatures. The particle distribution during this period was dominated by an elevated size mode at 160 $200 \mathrm{~nm}$, and the aerosol volume increased by a factor of 3 as the temperature increased from 10 to $30^{\circ} \mathrm{C}$ (Chi et al., 2013).

In this study, we use the filter-based $\mathrm{PM}_{10}$ and $\mathrm{OC}$ concentrations obtained during the near-pristine summer periods in 2010-2014 (14 time intervals, mostly of 3-11 days) together with average ground-level temperatures estimated from the NCEP/NCAR Reanalysis meteorological profiles along each trajectory for an analysis of the temperature dependence of aerosol concentrations. This is in contrast to the previous study (Chi et al., 2013), where aerosol particle size spectra and surface temperature were measured simultaneously at the ZOTTO site over $1 \mathrm{~h}$ intervals. For the analysis presented here we used trajectories initialised at $2 \mathrm{~m}$ height because the temperatures for these trajectories were representative of the surface temperature. A comparison of trajectory end points for 300 and $2 \mathrm{~m}$ starting height found simi- lar horizontal transport patterns, indicating that both trajectories represent horizontal flow in the boundary layer. The scatter plots of $\mathrm{PM}_{10}$ and $\mathrm{OC}$ vs. temperature (Fig. 14a and b) show no correlation. Most likely the long-range transport of aerosol particles to the ZOTTO site and variable meteorological conditions (wind direction, precipitation) obscured any effect of temperature variations on the particle mass concentration. However, Fig. 15 shows that the ratio OC / PM, which eliminates the effects of transport and removal processes that affect the absolute mass concentration, shows a strong dependence on temperature. There is a clear exponential temperature dependence of the OC / PM ratio, with $R^{2}=0.66$, which follows the exponential increase in the monoterpene emission rate observed for Scots pine (Isidorov et al., 1985), the dominant tree species in the West Siberia Lowland.

Our average summer background concentrations can be compared with those measured in the Amazon Basin (Brazil) at FNS (Fazenda Nossa Senhora Apareçida) during the wet period from 30 October to 14 November 2002 (Decesari et al., 2006) and at ATTO (Amazon Tall Tower Observatory) in the wet season, i.e. February-June 2014 (Andreae et al., 2015). The FNS site is located in a rural area in the state of Rondônia Brazil ( $10^{\circ} 45^{\prime} \mathrm{S} ; 62^{\circ} 21^{\prime} \mathrm{W}, 315 \mathrm{~m}$ a.s.l.), and the ATTO site is in the Uatumã Sustainable Development Reserve (USDR) in the central Amazon $\left(02^{\circ} 08^{\prime} \mathrm{S}\right.$; $59^{\circ} 00^{\prime} \mathrm{W}$ ). Complete descriptions of the FNS and ATTO sites are given by Andreae et al. (2002, 2015). For the FNS 
Table 6. Average background concentrations of carbonaceous species $( \pm \mathrm{SD})$ or min-max as well as their ratios obtained at FNS (Rondônia, Brazil) and at the ATTO site (Amazonas, Brazil) during the wet period and those measured in summertime at ZOTTO.

\begin{tabular}{|c|c|c|c|c|c|c|}
\hline \multirow[t]{2}{*}{ Site } & \multirow[t]{2}{*}{ Sampling period } & $\mathrm{EC}$ & $\mathrm{OC}$ & WSOC & $\mathrm{EC} / \mathrm{TC}$ & WSOC / OC \\
\hline & & $\mu \mathrm{g} \mathrm{m}^{-3}$ & $\mu \mathrm{g} \mathrm{m}^{-3}$ & $\mu \mathrm{g} \mathrm{m}^{-3}$ & & \\
\hline ZOTTO, Russia & 2010-2014, summer & $\begin{array}{r}0.03(0.02-0.06) \\
0.03 \pm 0.02\end{array}$ & $1.2(0.3-2.2)$ & $0.88(0.15-1.6)$ & $0.03 \pm 0.02$ & $0.69 \pm 0.12$ \\
\hline FNS, Brazil & $30 / 10-14 / 11 / 2002$, wet period & $0.05 \pm 0.03$ & $1.4(0.9-2.5)$ & $0.9(0.7-2.0)$ & $0.03 \pm 0.02$ & $0.60 \pm 0.12$ \\
\hline ATTO, Brazil & February-June 2014, wet season & $0.04(0.01-0.06)$ & $1.0(0.5-2.1)$ & $\mathrm{ND}^{*}$ & $0.05(0.02-0.09)$ & ND* \\
\hline
\end{tabular}

* ND stands for no data.
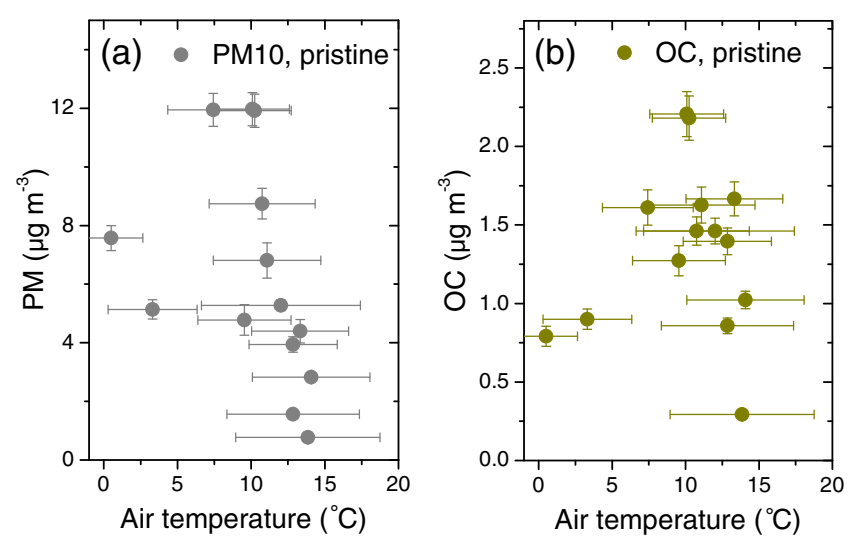

Figure 14. $\mathrm{PM}_{10}$ (a) and $\mathrm{OC}$ (b) concentration during pristine summer periods vs. averaged ground-level temperature $( \pm \mathrm{SD})$ estimated from the meteorological profiles along each trajectory.

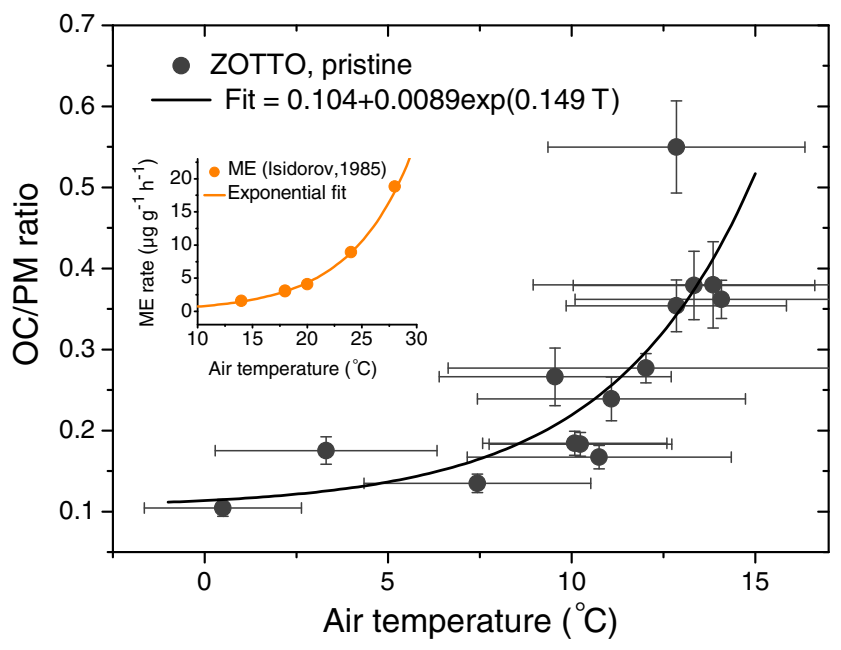

Figure 15. OC / $\mathrm{PM}$ ratios in $\mathrm{PM}_{10}$ for pristine conditions vs. averaged ground-level temperature $( \pm \mathrm{SD})$ estimated from the meteorological profiles along each trajectory. The coefficient of determination of the fit $\left(R^{2}\right)$ is 0.66 . The insert shows monoterpene emission (ME) rate from Scots pine vs. temperature (Isidorov et al., 1985) and the exponential fit: $\mathrm{ME}$ rate $=0.121 \cdot \exp \left[0.179 \cdot T\left({ }^{\circ} \mathrm{C}\right)\right]$ with $R^{2}=0.99$. samples, the same NIOSH 5040 temperature protocol was used for OC / EC analysis, while at ATTO an aerosol chemical speciation monitor (ACSM) (Ng et al., 2011) and a filterbased MAAP were used for $\mathrm{OC}$ and $\mathrm{BC}_{\mathrm{e}}$ determination, respectively. Accordingly, the $\mathrm{BC}_{\mathrm{e}} / \mathrm{EC}$ ratio of $1.67 \pm 0.05$ obtained in this study was applied to convert the $\mathrm{BC}_{\mathrm{e}}$ derived concentrations at ATTO into EC values. Table 6 summarises the carbonaceous species concentrations obtained at the Amazonian sites and at ZOTTO. It is seen that in spite of the strong difference in climatic zones and vegetation type, the EC, OC, and WSOC concentrations as well as their ratios are in fairly good agreement. In particular, the average concentrations of $\mathrm{OC}$ and the range of their variations are very close. This is likely the result of a combination of effects, where the production of biogenic SOA from VOCs is balanced by precipitation removal. In addition, aging processes, such as oxidation by ozone or hydroxyl radical, oligomerisation, and condensation, may largely offset the impact of the vegetation type on the SOA composition. A consequence of the atmospheric evolution of SOA is the convergence of its chemical composition and physical properties (Andreae, 2009). In particular, the $\mathrm{CCN}$ and hygroscopic properties of the SOA formed in the rain forest and boreal forest environments become very similar (Mikhailov et al., 2015b; Pöhlker et al., 2016).

\section{Conclusions}

We presented time series of $\mathrm{CO}, \mathrm{PM}_{10}$, and carbonaceous species (EC, OC, WSOC) concentrations measured at the ZOTTO site in central Siberia from April 2010 to June 2014. Using a non-parametric statistical approach, we separated the time intervals representing background and polluted air. Further, based on the elemental carbon detection limit we selected near-pristine periods. We used the HYSPLIT back trajectory model coupled with the NCEP/NCAR meteorological data set to trace the air mass trajectories for selected time periods and to estimate meteorological parameters along the trajectories. In addition, the satellite MODIS instrument was used for monitoring of fires.

In the summer season, when $\mathrm{CO}$ mixing ratio, $\mathrm{PM}_{10}$, and carbonaceous species concentrations reach their max- 
ima, aerosol particles from large-scale boreal wildfires are dominant. Overall, $48 \%$ of air masses in the summer season are classified as polluted, with pollutants originating mostly from nearby forest fires. These plumes are associated with extremely high seasonal concentrations of $\mathrm{CO}(667 \pm 711 \mathrm{ppb}), \mathrm{PM}_{10}\left(59.4 \pm 53.1 \mu \mathrm{g} \mathrm{m}^{-3}\right)$, and $\mathrm{OC}$ $\left(26.1 \pm 26.7 \mu \mathrm{g} \mathrm{m}^{-3}\right)$, with $\Delta \mathrm{OC} / \Delta \mathrm{EC}$ and $\Delta \mathrm{EC} / \Delta \mathrm{CO}$ ratios of $26.2 \pm 0.1$ and $1.3 \pm 0.1 \mathrm{ng} \mathrm{m}^{-3} \mathrm{ppb}^{-1}$, respectively.

In winter, polluted air masses account for $75 \%$ of days at ZOTTO. The HYSPLIT trajectory analysis shows that pollution plumes originate mainly from the big industrialised cities to the south and southwest of the site. During the winter pollution events the $\Delta \mathrm{OC} / \triangle \mathrm{EC}$ and $\Delta \mathrm{EC} / \Delta \mathrm{CO}$ ratios are $3.9 \pm 0.6$ and $5.8 \pm 0.7 \mathrm{ng} \mathrm{m}^{-3} \mathrm{ppb}^{-1}$, respectively, suggesting that the contribution of coal and fossil burning for heating was dominant.

Our analysis of the spring aerosol samples indicates that elevated $\mathrm{CO}$ and aerosol species concentrations associated with long-range transport of pollution plumes from the steppe zone of southern Siberia and northern Kazakhstan result from agricultural fires. For one extreme pollution episode observed on 28 April 2010, the $\mathrm{CO}, \mathrm{PM}_{10}, \mathrm{EC}$, and $\mathrm{OC}$ concentrations were as high as $261 \pm 12 \mathrm{ppb}, 54.4 \pm 3.7,1.5 \pm 0.3$, and $18.9 \pm 1.2 \mu \mathrm{g} \mathrm{m}^{-3}$, respectively, with $\Delta \mathrm{OC} / \triangle \mathrm{EC}=12.7 \pm 2.7$ and $\Delta \mathrm{EC} / \Delta \mathrm{CO}=14.3 \pm 4.4 \mathrm{ng} \mathrm{m}^{-3} \mathrm{ppb}^{-1}$. Overall, the frequency of polluted episodes in the spring season was estimated to be $42 \%$.

In fall, the most polluted air masses arriving at ZOTTO were caused by anthropogenic emissions from southern and southwestern urban and industrial sites enriched by combustion products from scattered agricultural fires with $\triangle \mathrm{OC} / \triangle \mathrm{EC}$ ratios of $18.3 \pm 4.0$ and $\Delta \mathrm{EC} / \Delta \mathrm{CO}$ of $6.0 \pm 2.0 \mathrm{ng} \mathrm{m}^{-3} \mathrm{ppb}^{-1}$. Over the entire fall season, $42 \%$ air masses were classified as polluted.

Based on the REBS selection algorithm, the frequency of background conditions by season is $25,58,39$, and $58 \%$ for winter, spring, summer, and fall, respectively. The EC and $\mathrm{CO}$ background concentrations show a sine-like behaviour with maximum values in winter of $151 \pm 20 \mathrm{ppb}$ and $0.08 \pm 0.03 \mu \mathrm{g} \mathrm{m}^{-3}$ and minimum values in summer of $114 \pm 15 \mathrm{ppb}$ and $0.03 \pm 0.02 \mu \mathrm{g} \mathrm{m}^{-3}$, respectively. The observed background concentrations are mostly due to different degrees of dilution and the removal of pollution in the air masses arriving at the ZOTTO site from remote sources.

Our analysis of the near pristine conditions, based on the EC detection limit of $0.02 \pm 0.01 \mu \mathrm{gC} \mathrm{m}{ }^{-3}$, shows that the longest periods with clean air masses were observed in summer (frequency of $17 \%$ ). For this period, the variations in the OC / PM ratio closely correlated with those in air temperature, which implies that biogenic sources of OC formation were dominant. Against a low concentration of $\mathrm{CO}, \mathrm{EC}$, and OC observed in the near-pristine summer episodes, it was possible to identify pollution plumes that most likely arrived at ZOTTO from crude-oil production sites located in the oilrich regions of Western Siberia.

Over the entire measurement campaign, the WSOC / OC ratio remains relatively stable and ranged from 0.5 to 0.7 , indicating that partitioning between water-soluble and waterinsoluble organic matter is not significantly dependent on the source of the polluted air mass. Most likely, aging processes and precipitation scavenging control the ratio between them.

Further studies at ZOTTO may investigate the link between aerosol and climate: e.g. the influence of rising temperatures on an enhancement of biogenic SOA formation as well as a quantification of anthropogenic emissions, which produce feedbacks on cloud formation, tropospheric radiation balance, and precipitation patterns (Kulmala et al., 2004; Goetz et al., 2007). The continuing measurements at ZOTTO will help to detect these trends in aerosol emissions and their influences on future climate.

Data availability. Data used in this study can be made available upon request to the author.

Competing interests. The authors Martin Heimann, Ulrich Pöschl and Meinrat O. Andreae are members of the editorial board of the journal.

Special issue statement. This article is part of the special issue "Pan-Eurasian Experiment (PEEX)". It is not associated with a conference.

Acknowledgements. This work was supported by the Max Planck Society (MPG), RFBR grants 16-05-00718 and 16-05-00717, and Saint Petersburg State University (SPBU) grant BRICS 11.37.220.2016. We thank the Geomodel Research Center at Saint Petersburg State University for help with the chemical analysis of the ambient aerosol samples. We acknowledge Christopher Pöhlker, Karl Kuebler, and Steffen Schmidt for their generous help during the ZOTTO campaign. This work was partly performed within the research agenda of the Pan-Eurasian Experiment (PEEX) (https://www.atm.helsinki.fi/peex/).

The article processing charges for this open-access publication were covered by the Max Planck Society.

Edited by: Imre Salma

Reviewed by: two anonymous referees 


\section{References}

Alonso-Blanco, E., Calvo, A. I., Pont, V., Mallet, M., Fraile, R., and Castro, A.: Impact of biomass burning on aerosol size distribution, aerosol optical properties and associated radiative forcing, Aerosol Air Qual. Res., 14, 708-724, https://doi.org/10.4209/aaqr.2013.05.0163, 2014.

Andreae, M. O.: Aerosols before pollution, Science, 315, 50-51, 2007.

Andreae, M. O.: A New Look at Aging Aerosols, Science, 326, 1493-1494, https://doi.org/10.1126/science.1183158, 2009.

Andreae, M. O. and Merlet, P.: Emission of trace gases and aerosols from biomass burning, Global Biogeochem. Cy., 15, 955-966, https://doi.org/10.1029/2000GB001382, 2001.

Andreae, M. O. and Gelencsér, A.: Black carbon or brown carbon? The nature of light-absorbing carbonaceous aerosols, Atmos. Chem. Phys., 6, 3131-3148, https://doi.org/10.5194/acp-63131-2006, 2006.

Andreae, M. O. and Ramanathan, V.: Climate's Dark Forcings, Science, 340, 280-281, https://doi.org/10.1126/science.1235731, 2013.

Andreae, M. O. and Rosenfeld, D.: Aerosol-cloud-precipitation interactions. Part 1. The nature and sources of cloud-active aerosols, Earth Sci. Rev., 89, 13-41, 2008.

Andreae, M. O., Artaxo, P., Fischer, H., Freitas, S. R., Gregoire, J. M., Hansel, A., Hoor, P., Kormann, R., Krejci, R., Lange, L., Lelieveld, J., Lindinger, W., Longo, K., Peters, W., Reus, M. D., Scheeren, B., Silva Dias, M. A. F., Ström, J., van Velthoven, P. F. J., and Williams, J.: Transport of biomass burning smoke to the upper troposphere by deep convection in the equatorial region, Geophys. Res. Lett., 28, 951-954, 2001.

Andreae, M. O., Artaxo, P., Brandao, C., Carswell, F. E., Ciccioli, P., da Costa, A. L., Culf, A. E., Esteves, J. L., Gash, H. C., Grace, J., Kabat, P., Lelieveld, J., Malhi, Y., Manzi, A. O., Meixner, F. X., Nobre, A. D., Nobre, C., Ruivo, M. d. L. P., Silva-Dias, M. A., Stefani, P., Valentini, R., von Jouanne, J., and Waterloo, M. J.: Biogeochemical cycling of carbon, water, energy, trace gases, and aerosols in Amazonia: The LBA-EUSTACH experiments, J. Geophys. Res., 107, 8066, https://doi.org/10.1029/2001JD000524, 2002.

Andreae, M. O., Rosenfeld, D., Artaxo, P., Costa, A. A., Frank, G. P., Longo, K. M., and Silva-Dias, M. A. F.: Smoking rain clouds over the Amazon, Science, 303, 1337-1342, 2004.

Andreae, M. O., Schmid, O., Yang, H., Chand, D., Yu, J. Z., Zeng, L.-M., and Zhang, Y.-H.: Optical properties and chemical composition of the atmospheric aerosol in urban Guangzhou, China, Atmos. Environ., 42, 6335-6350, 2008.

Andreae, M. O., Acevedo, O. C., Araùjo, A., Artaxo, P., Barbosa, C. G. G., Barbosa, H. M. J., Brito, J., Carbone, S., Chi, X., Cintra, B. B. L., da Silva, N. F., Dias, N. L., Dias-Júnior, C. Q., Ditas, F., Ditz, R., Godoi, A. F. L., Godoi, R. H. M., Heimann, M., Hoffmann, T., Kesselmeier, J., Könemann, T., Krüger, M. L., Lavric, J. V., Manzi, A. O., Lopes, A. P., Martins, D. L., Mikhailov, E. F., Moran-Zuloaga, D., Nelson, B. W., Nölscher, A. C., Santos Nogueira, D., Piedade, M. T. F., Pöhlker, C., Pöschl, U., Quesada, C. A., Rizzo, L. V., Ro, C.-U., Ruckteschler, N., Sá, L. D. A., de Oliveira Sá, M., Sales, C. B., dos Santos, R. M. N., Saturno, J., Schöngart, J., Sörgel, M., de Souza, C. M., de Souza, R. A. F., Su, H., Targhetta, N., Tóta, J., Trebs, I., Trumbore, S., van Eijck, A., Walter, D., Wang, Z., Weber, B., Williams,
J., Winderlich, J., Wittmann, F., Wolff, S., and Yáñez-Serrano, A. M.: The Amazon Tall Tower Observatory (ATTO): overview of pilot measurements on ecosystem ecology, meteorology, trace gases, and aerosols, Atmos. Chem. Phys., 15, 10723-10776, https://doi.org/10.5194/acp-15-10723-2015, 2015.

Anejionu, O. C. D., Blackburn, G. A., and Whyatt, J. D.: Detecting gas flares and estimating flaring volumes at individual flow stations using MODIS data, Remote Sens. Environ., 158, 81-94, https://doi.org/10.1016/j.rse.2014.11.018, 2015.

Bergeron, T.: On the physics of clouds and precipitation. Proces Verbaux de l'Association de Météorologie, International Union of Geodesy and Geophysics, 156-178, 1935.

Bergström, R., Hallquist, M., Simpson, D., Wildt, J., and Mentel, T. F.: Biotic stress: a significant contributor to organic aerosol in Europe?, Atmos. Chem. Phys., 14, 13643-13660, https://doi.org/10.5194/acp-14-13643-2014, 2014.

Bigg, E. K., Soubeyrand, S., and Morris, C. E.: Persistent aftereffects of heavy rain on concentrations of ice nuclei and rainfall suggest a biological cause, Atmos. Chem. Phys., 15, 2313-2326, https://doi.org/10.5194/acp-15-2313-2015, 2015.

Birch, M. E.: Analysis of carbonaceous aerosols: interlaboratory comparison, Analyst, 123, 851-857, 1998.

Birch, M. E. and Cary, R. A.: Elemental carbon-based method for monitoring occupational exposures to particulate diesel exhaust, Aerosol Sci. Tech., 25, 221-241, 1996.

Birmili, W., Stopfkuchen, K., Hermann, M., Wiedensohler, A., and Heintzenberg, J.: Particle penetration through a $300 \mathrm{~m}$ inlet pipe for sampling atmospheric aerosols from a tall meteorological tower, Aerosol Sci. Tech., 41, 811-817, 2007.

Bond, T. C., Habib, G., and Bergstrom, R. W.: Limitations in the enhancement of visible light absorption due to mixing state, J. Geophys. Res., 111, D20211, https://doi.org/10.1029/2006JD007315, 2006.

Bond, T. C., Doherty, S. J., Fahey, D. W., et al.: Bounding the role of black carbon in the climate system: A scientific assessment, J. Geophys. Res.-Atmos., 118, 5380-5552, https://doi.org/10.1002/jgrd.50171, 2013.

Burtscher, H., Leonardi, A., Steiner, D., Baltensperger, U., and Weber, A.: Aging of combustion particles in the atmosphere - results from a field study in Zurich, Water Air Soil Pollut., 68, 137-147, https://doi.org/10.1007/BF00479398, 1993.

Cao, J. J., Wu, F., Chow, J. C., Lee, S. C., Li, Y., Chen, S. W., An, Z. S., Fung, K. K., Watson, J. G., Zhu, C. S., and Liu, S. X.: Characterization and source apportionment of atmospheric organic and elemental carbon during fall and winter of 2003 in Xi' an, China, Atmos. Chem. Phys., 5, 3127-3137, https://doi.org/10.5194/acp5-3127-2005, 2005.

Carrico, C. M., Petters, M. D., Kreidenweis, S. M., Collet Jr., J. L., Engling, G., and Malm, W. C.: Aerosol hygroscopicity and cloud droplet activation of extracts of filters from biomass burning experiments, J. Geophys. Res., 113, D08206, https://doi.org/10.1029/2007JD009274, 2008.

Carslaw, K. S., Lee, L. A., Reddington, C. L., Pringle, K. J., Rap, A., Forster, P. M., Mann, G. W., Spracklen, D. V., Woodhouse, M. T., Regayre, L. A., and Pierce, J. R.: Large contribution of natural aerosols to uncertainty in indirect forcing, Nature, 503, 67-71, 2013.

Cerqueira, M., Pio, C., Legrand, M., Puxbaum, H., Kasper-Giebl, A., Afonso, J., Preunkert, S., Gelencsér, A., and Fialho, P.: Par- 
ticulate carbon in precipitation at European background sites, J. Aerosol Sci., 41, 51-61, 2010.

Cerully, K. M., Raatikainen, T., Lance, S., Tkacik, D., Tiitta, P., Petäjä, T., Ehn, M., Kulmala, M., Worsnop, D. R., Laaksonen, A., Smith, J. N., and Nenes, A.: Aerosol hygroscopicity and CCN activation kinetics in a boreal forest environment during the 2007 EUCAARI campaign, Atmos. Chem. Phys., 11, 12369-12386, https://doi.org/10.5194/acp-11-12369-2011, 2011.

Cheng, Y., He, K.-B., Zheng, M., Duan, F.-K., Du, Z.-Y., Ma, Y.-L., Tan, J.-H., Yang, F.-M., Liu, J.-M., Zhang, X.-L., Weber, R. J., Bergin, M. H., and Russell, A. G.: Mass absorption efficiency of elemental carbon and water-soluble organic carbon in Beijing, China, Atmos. Chem. Phys., 11, 11497-11510, https://doi.org/10.5194/acp-11-11497-2011, 2011.

Cheng, Y., He, K.-B., Duan, F.-K., Du, Z.-Y., Zheng, M., and Ma, Y.-L.: Ambient organic carbon to elemental carbon ratios: Influence of the thermal-optical temperature protocol and implications, Sci. Total Environ., 468-469, 1103-1111, https://doi.org/10.1016/j.scitotenv.2013.08.084, 2014.

Chi, X.: Development of improved sampling and analysis methods for measuring organic, elemental, and water-soluble organic carbon in atmospheric aerosols and application to aerosol studies in Europe and tropical/equatorial and oceanic regions, $\mathrm{PhD}$ thesis, Ghent University, ISBN: 978-90-5989-328-3, 440 pp., 2009.

Chi, X., Winderlich, J., Mayer, J.-C., Panov, A. V., Heimann, M., Birmili, W., Heintzenberg, J., Cheng, Y., and Andreae, M. O.: Long-term measurements of aerosol and carbon monoxide at the ZOTTO tall tower to characterize polluted and pristine air in the Siberian taiga, Atmos. Chem. Phys., 13, 12271-12298, https://doi.org/10.5194/acp-13-12271-2013, 2013.

Chow, J. C., Watson, J. G., Crow, D., Lowenthal, D. H., and Merrifield, T.: Comparison of IMPROVE and NIOSH carbon measurements, Aerosol Sci. Tech., 34, 23-34, 2001.

Conard, S. G. and Ivanova, G. A.: Wildfire in Russian boreal forests - Potential impacts of fire regime characteristics on emissions and global carbon balance estimates, Environ. Pollut., 98, 305313, 1997.

Corrigan, A. L., Russell, L. M., Takahama, S., Äijälä, M., Ehn, M., Junninen, H., Rinne, J., Petäjä, T., Kulmala, M., Vogel, A. L., Hoffmann, T., Ebben, C. J., Geiger, F. M., Chhabra, P., Seinfeld, J. H., Worsnop, D. R., Song, W., Auld, J., and Williams, $\mathrm{J} .:$ Biogenic and biomass burning organic aerosol in a boreal forest at Hyytiälä, Finland, during HUMPPA-COPEC 2010, Atmos. Chem. Phys., 13, 12233-12256, https://doi.org/10.5194/acp-1312233-2013, 2013.

Cozic, J., Verheggen, B., Mertes, S., Connolly, P., Bower, K., Petzold, A., Baltensperger, U., and Weingartner, E.: Scavenging of black carbon in mixed phase clouds at the high alpine site Jungfraujoch, Atmos. Chem. Phys., 7, 1797-1807, https://doi.org/10.5194/acp-7-1797-2007, 2007.

Cristofanelli, P., Fierli, F., Marinoni, A., Calzolari, F., Duchi, R., Burkhart, J., Stohl, A., Maione, M., Arduini, J., and Bonasoni, P.: Influence of biomass burning and anthropogenic emissions on ozone, carbon monoxide and black carbon at the Mt. Cimone GAW-WMO global station (Italy, $2165 \mathrm{~m}$ a.s.1.), Atmos. Chem. Phys., 13, 15-30, https://doi.org/10.5194/acp-13-15-2013, 2013.

Decesari, S., Fuzzi, S., Facchini, M. C., Mircea, M., Emblico, L., Cavalli, F., Maenhaut, W., Chi, X., Schkolnik, G., Falkovich, A., Rudich, Y., Claeys, M., Pashynska, V., Vas, G., Kourtchev,
I., Vermeylen, R., Hoffer, A., Andreae, M. O., Tagliavini, E., Moretti, F., and Artaxo, P.: Characterization of the organic composition of aerosols from Rondônia, Brazil, during the LBA-SMOCC 2002 experiment and its representation through model compounds, Atmos. Chem. Phys., 6, 375-402, https://doi.org/10.5194/acp-6-375-2006, 2006.

Després, V. R., Huffman, J. A., Burrows, S. M., Hoose, C., Safatov, A. S., Buryak, G., Fröhlich-Nowoisky, J., Elbert, W., Andreae, M. O., Pöschl, U., and Jaenicke, R.: Primary biological aerosol particles in the atmosphere: a review, Tellus B, 64, 1-58, 2012.

Dhammapala, R., Claiborn, C., Simpson, C., and Jimenez, J.: Emission factors from wheat and Kentucky bluegrass stubble burning: Comparison of field and simulated burn experiments, Atmos. Environ., 41, 1512-1520, https://doi.org/10.1016/j.atmosenv.2006.10.008, 2007a.

Dhammapala, R. S., Claiborn, C. S., Simpson, C., Gullett, B. K., and Paulsen, M.: Emission factors of PAHs, methoxyphenols, elemental carbon and organic carbon from simulated wheat and Kentucky bluegrass stubble burns, Atmos. Environ., 41, 26602669, https://doi.org/10.1016/j.atmosenv.2006.11.023, 2007b.

Ebben, C. J., Martinez, I. S., Shrestha, M., Buchbinder, A. M., Corrigan, A. L., Guenther, A., Karl, T., Petäjä, T., Song, W. W., Zorn, S. R., Artaxo, P., Kulmala, M., Martin, S. T., Russell, L. M., Williams, J., and Geiger, F. M.: Contrasting organic aerosol particles from boreal and tropical forests during HUMPPA-COPEC-2010 and AMAZE-08 using coherent vibrational spectroscopy, Atmos. Chem. Phys., 11, 10317-10329, https://doi.org/10.5194/acp-11-10317-2011, 2011.

Ehn, M., Petäjä, T., Aufmhoff, H., Aalto, P., Hämeri, K., Arnold, F., Laaksonen, A., and Kulmala, M.: Hygroscopic properties of ultrafine aerosol particles in the boreal forest: diurnal variation, solubility and the influence of sulfuric acid, Atmos. Chem. Phys., 7, 211-222, https://doi.org/10.5194/acp-7-211-2007, 2007.

Ehn, M., Kleist, E., Junninen, H., Petäjä, T., Lönn, G., Schobesberger, S., Dal Maso, M., Trimborn, A., Kulmala, M., Worsnop, D. R., Wahner, A., Wildt, J., and Mentel, Th. F.: Gas phase formation of extremely oxidized pinene reaction products in chamber and ambient air, Atmos. Chem. Phys., 12, 5113-5127, https://doi.org/10.5194/acp-12-5113-2012, 2012.

Elvidge, C. D., Baugh, K. E., Ziskin, D., Anderson, S., and Ghosh, T.: Estimation of Gas Flaring Volumes Using NASA MODIS Fire Detection Products, NOAA National Geophysical Data Center (NGDC), annual report, 8, 2011.

Findeisen, W.: Kolloid-meteorologische Vorgänge bei Niederschlagsbildung, Meteorol. Z., 55, 121-133, 1938.

Fröhlich-Nowoisky, J., Kampf, C. J., Weber, B., Huffman, J. A., Pöhlker, C., Andreae, M. O., Lang-Yona, N, Burrows, S. M., Gunthe, S. S., Elbert, W., Su, H., Hoor, P., Thines, E., Hoffmann, T., Després, V. R., and Pöschl, U.: Bioaerosols in the Earth system: Climate, health, and ecosystem interactions, Atmos. Res., 182, 346-376, https://doi.org/10.1016/j.atmosres.2016.07.018, 2016.

Fuzzi, S., Decesari, S., Facchini, M. C., Cavalli, F., Emblico, L., Mircea, M., Andreae, M. O., Trebs, I., Hoffer, A., Guyon, P., Artaxo, P., Rizzo, L. V., Lara, L. L., Pauliquevis, T., Maenhaut, W., Raes, N., Chi, X., Mayol-Bracero, O. L., Soto-Garcia, L. L., Claeys, M., Kourtchev, I., Rissler, J., Swietlicki, E., Tagliavini, E., Schkolnik, G., Falkovich, A. H., Rudich, Y., Fisch, G., and Gatti, L. V.: Overview of the inorganic and organic composition 
of size-segregated aerosol in Rondônia, Brazil, from the biomass burning period to the onset of the wet season, J. Geophys. Res., 112, D01201, https://doi.org/10.1029/2005JD006741, 2007.

Gaubert, B., Arellano, A. F., Barré, J., Worden, H. M., Emmons, L. K., Tilmes, S., Buchholz, R. R.,Vitt, F., Raeder, K., Collins, N., Anderson, J. L., Wiedinmyer, C., Martinez Alonso, S., Edwards, D. P., Andreae, M. O., Hannigan, J. W., Petri, C., Strong, K., and Jones, N.: Toward a chemical reanalysis in a coupled chemistry-climate model: An evaluation of MOPITT CO assimilation and its impact on tropospheric composition, J. Geophys. Res.-Atmos., 121, 7310-7343, https://doi.org/10.1002/2016JD024863, 2016.

Giglio, L., Descloitres, J., Justice, C. O., and Kaufman, Y. J.: An enhanced contextual fire detection algorithm for MODIS, Remote Sens. Environ., 87, 273-282, https://doi.org/10.1016/S00344257(03)00184-6, 2003

Goetz, S. J., Mack, M. C., Gurney, K. R., Randerson, J. T., and Houghton, R. A.: Ecosystem responses to recent climate change and fire disturbance at northern high latitudes: observations and model results contrasting northern Eurasia and North America, Environ. Res. Lett., 2, 045031, https://doi.org/10.1088/17489326/2/4/045031, 2007

Groisman, P. and Soja, A. J.: Ongoing climatic change in Northern Eurasia: justification for expedient research, Environ. Res. Lett., 4, 045002, https://doi.org/10.1088/1748-9326/4/4/045002, 2009.

Hallquist, M., Wenger, J. C., Baltensperger, U., Rudich, Y., Simpson, D., Claeys, M., Dommen, J., Donahue, N. M., George, C., Goldstein, A. H., Hamilton, J. F., Herrmann, H., Hoffmann, T., Iinuma, Y., Jang, M., Jenkin, M. E., Jimenez, J. L., Kiendler-Scharr, A., Maenhaut, W., McFiggans, G., Mentel, Th. F., Monod, A., Prévôt, A. S. H., Seinfeld, J. H., Surratt, J. D., Szmigielski, R., and Wildt, J.: The formation, properties and impact of secondary organic aerosol: current and emerging issues, Atmos. Chem. Phys., 9, 5155-5236, https://doi.org/10.5194/acp9-5155-2009, 2009.

Hamilton, D. S., Lee, L. A., Pringle, K. J., Reddington, C. L., Spracklen, D. V., and Carslaw, K. S.: Occurrence of pristine aerosol environments on a polluted planet, P. Natl. Acad. Sci. USA, 111, 18466-18471, https://doi.org/10.1073/pnas.1415440111, 2014.

Han, S., Kondo, Y., Takegawa, N., Miyazaki, Y., Oshima, N., Hu, M., Lin, P., Deng, Z., Zhao, Y., Sugimoto, N., and Wu, Y.: Temporal variation of elemental carbon in Beijing, J. Geophys. Res., 114, D23202, https://doi.org/10.1029/2009JD012027, 2009.

Hansen, J., Sato, M., Ruedy, R., Lo, K., Lea, D. W., and MedinaElzade, M.: Global temperature change, P. Natl. Acad. Sci. USA, 103, 14288-14293, https://doi.org/10.1073/pnas.0606291103, 2006.

Hayashi, K., Ono, K., Kajiura, M., Sudo, S., Yonemura, S., Fushimi, A., Saitoh, K., Fujitani, Y., and Tanabe, K.: Trace gas and particle emissions from open burning of three cereal crop residues: Increase in residue moistness enhances emissions of carbon monoxide, methane, and particulate organic carbon, Atmos. Environ., 95, 36-44, https://doi.org/10.1016/j.atmosenv.2014.06.023, 2014.

Haywood, J. and Boucher, O.: Estimates of the direct and indirect radiative forcing due to tropospheric aerosols, A review, Rev. Geophys., 38, 513-543, https://doi.org/10.1029/1999RG000078, 2000 .
Heimann, M., Schulze, E.-D., Winderlich, J., Andreae, M. O., Chi, X., Gerbig, C., Kolle, O., Kübler, K., Lavric, J., Mikhailov, E., Panov, A., Park, S., Rödenbeck, C., and Skorochod, A.: The Zotino Tall Tower Observatory (ZOTTO): Quantifying large scale biogeochemical changes in Central Siberia, Nova Act. Lc., $117,51-64,2014$.

Heintzenberg, J. and Birmili, W.: Aerosols over the Siberian Forest: The ZOTTO project, J. Cryogenic Soc. Jpn., 68, 5-8, 2010.

Heintzenberg, J., Birmili, W., Theiss, D., and Kisilyakhov, Y.: The atmospheric aerosol over Siberia, as seen from the $300 \mathrm{~m}$ ZOTTO tower, Tellus B, 60, 276-285, 2008.

Heintzenberg, J., Birmili, W., Otto, R., Andreae, M. O., Mayer, J.C., Chi, X., and Panov, A.: Aerosol particle number size distributions and particulate light absorption at the ZOTTO tall tower (Siberia), 2006-2009, Atmos. Chem. Phys., 11, 87038719, https://doi.org/10.5194/acp-11-8703-2011, 2011.

Heintzenberg, J., Birmili, W., Seifert, P., Panov, A., Chi, X., and Andreae, M. O.: Mapping the aerosol over Eurasia from the Zotino Tall Tower, Tellus B, 65, 20062, https://doi.org/10.3402/tellusb.v65i0.20062, 2013.

Hoffer, A., Gelencsér, A., Blazsó, M., Guyon, P., Artaxo, P., and Andreae, M. O.: Diel and seasonal variations in the chemical composition of biomass burning aerosol, Atmos. Chem. Phys., 6, 3505-3515, https://doi.org/10.5194/acp-6-3505-2006, 2006.

Huff Hartz, K. E., Rosenørn, T., Ferchak, S. R., Raymond, T. M., Bilde, M., Donahue, N. M., and Pandis, S. N.: Cloud condensation nuclei activation of monoterpene and sesquiterpenes secondary organic aerosol, J. Geophys. Res., 110, D14208, https://doi.org/10.1029/2004JD005754, 2005.

Huffman, J. A., Sinha, B., Garland, R. M., Snee-Pollmann, A., Gunthe, S. S., Artaxo, P., Martin, S. T., Andreae, M. O., and Pöschl, U.: Size distributions and temporal variations of biological aerosol particles in the Amazon rainforest characterized by microscopy and real-time UV-APS fluorescence techniques during AMAZE-08, Atmos. Chem. Phys., 12, 11997-12019, https://doi.org/10.5194/acp-12-11997-2012, 2012.

Huffman, J. A., Prenni, A. J., DeMott, P. J., Pöhlker, C., Mason, R. H., Robinson, N. H., Fröhlich-Nowoisky, J., Tobo, Y., Després, V. R., Garcia, E., Gochis, D. J., Harris, E., MüllerGermann, I., Ruzene, C., Schmer, B., Sinha, B., Day, D. A., Andreae, M. O., Jimenez, J. L., Gallagher, M., Kreidenweis, S. M., Bertram, A. K., and Pöschl, U.: High concentrations of biological aerosol particles and ice nuclei during and after rain, Atmos. Chem. Phys., 13, 6151-6164, https://doi.org/10.5194/acp13-6151-2013, 2013.

IPCC: Climate Change: Impacts, Adaptation, and Vulnerability. Working Group II Contribution to the Fifth Assessment Report of the Intergovernmental Panel on Climate Change, edited by: Field, C. B., Barros, V. R., Dokken, D. J., Mach, K. J., and Mastrandrea M. D., Cambridge University Press, Cambridge, UK, 2014.

Isidorov, V. A., Zenkevich, I. G., and Ioffe, B. V.: Volatile organic compounds in the atmosphere of forests, Atmos. Environ., 19, $1-8,1985$.

Jaatinen, A., Romakkaniemi, S., Anttila, T., Hyvärinen, A.-P., Hao, L.-Q., Kortelainen, A., Miettinen P., Mikkonen, S., Smith, J. S., Virtanen, A., and Laaksonen, A.: The third Pallas Cloud Experiment: Consistency between the aerosol hygroscopic growth 
and CCN activity, Boreal Environ. Res., 19 (suppl. B), 368-382, 2014.

Janhäll, S., Andreae, M. O., and Pöschl, U.: Biomass burning aerosol emissions from vegetation fires: particle number and mass emission factors and size distributions, Atmos. Chem. Phys., 10, 1427-1439, https://doi.org/10.5194/acp-101427-2010, 2010.

Jimenez, J. L., Canagaratna, M. R., Donahue, N. M., et al.: Evolution of organic aerosols in the Atmosphere, Science, 326, 15251529, https://doi.org/10.1126/science.1180353, 2009.

Joutsensaari, J., Yli-Pirilä, P., Korhonen, H., Arola, A., Blande, J. D., Heijari, J., Kivimäenpää, M., Mikkonen, S., Hao, L., Miettinen, P., Lyytikäinen-Saarenmaa, P., Faiola, C. L., Laaksonen, A., and Holopainen, J. K.: Biotic stress accelerates formation of climate-relevant aerosols in boreal forests, Atmos. Chem. Phys., 15, 12139-12157, https://doi.org/10.5194/acp-15-121392015, 2015.

Kalnay, E., Kanamitsu, M., Kistler, R., Collins, W., Deaven, D., Gandin, L., Iredell, M., Saha, S., White, G., Woollen, J., Zhu, Y., Leetmaa, A., Reynolds, R., Chelliah, M., Ebisuzaki, W., Higgins, W., Janowiak, J., Mo, K. C., Ropelewski, C., Wang, J., Jenne, R., and Joseph, D.: The NCEP/NCAR 40-Year Reanalysis Project, B. Am. Meteorol. Soc., 77, 437-471, https://doi.org/10.1175/15200477(1996)077<0437:TNYRP>2.0.CO;2, 1996.

Kanakidou, M., Seinfeld, J. H., Pandis, S. N., Barnes, I., Dentener, F. J., Facchini, M. C., Van Dingenen, R., Ervens, B., Nenes, A., Nielsen, C. J., Swietlicki, E., Putaud, J. P., Balkanski, Y., Fuzzi, S., Horth, J., Moortgat, G. K., Winterhalter, R., Myhre, C. E. L., Tsigaridis, K., Vignati, E., Stephanou, E. G., and Wilson, J.: Organic aerosol and global climate modelling: a review, Atmos. Chem. Phys., 5, 1053-1123, https://doi.org/10.5194/acp-5-10532005, 2005.

Kanaya, Y., Komazaki, Y., Pochanart, P., Liu, Y., Akimoto, H., Gao, J., Wang, T., and Wang, Z.: Mass concentrations of black carbon measured by four instruments in the middle of Central East China in June 2006, Atmos. Chem. Phys., 8, 7637-7649, https://doi.org/10.5194/acp-8-7637-2008, 2008.

Kanaya, Y., Pan, X., Miyakawa, T., Komazaki, Y., Taketani, F., Uno, I., and Kondo, Y.: Long-term observations of black carbon mass concentrations at Fukue Island, western Japan, during 2009-2015: constraining wet removal rates and emission strengths from East Asia, Atmos. Chem. Phys., 16, 1068910705, https://doi.org/10.5194/acp-16-10689-2016, 2016.

Kiss, G., Varga, B., Galambos, I., and Ganszky, I.: Characterization of water-soluble organic matter isolated from atmospheric fine aerosol, J. Geophys. Res., 107, 8339, https://doi.org/10.1029/2001JD000603, 2002.

Kondo, Y., Komazaki, Y., Miyazaki, Y., Moteki, N., Takegawa, N., Kodama, D., Deguchi, S., Nogami, M., Fukuda, M., Miyakawa, T., Morino, Y., Koike, M., Sakurai, H., and Ehara, K.: Temporal variations of elemental carbon in Tokyo, J. Geophys. Res., 111, D12205, https://doi.org/10.1029/2005JD006257, 2006.

Kondo, Y., Matsui, H., Moteki, N., Sahu, L., Takegawa, N., Kajino, M., Zhao, Y., Cubison, M. J., Jimenez, J. L., Vay, S., Diskin, G. S., Anderson, B., Wisthaler, A., Mikoviny, T., Fuelberg, H. E., Blake, D. R., Huey, G., Weinheimer, A. J., Knapp, D. J., and Brune, W. H.: Emissions of black carbon, organic, and inorganic aerosols from biomass burning in North
America and Asia in 2008, J. Geophys. Res., 116, D08204, https://doi.org/10.1029/2010JD015152, 2011 a.

Kondo, Y., Sahu, L., Moteki, N., Khan, F., Takegawa, N., Liu, X., Koike, M., and Miyakawa, T.: Consistency and traceability of black carbon measurements made by laser-induced Incandescence, thermal-optical transmittance, and filter-based photo-absorption techniques, Aerosol Sci. Tech., 45, 295-312, https://doi.org/10.1080/02786826.2010.533215, 2011 b.

Konovalov, I. B., Beekmann, M., Berezin, E. V., Petetin, H., Mielonen, T., Kuznetsova, I. N., and Andreae, M. O.: The role of semi-volatile organic compounds in the mesoscale evolution of biomass burning aerosol: a modeling case study of the 2010 mega-fire event in Russia, Atmos. Chem. Phys., 15, 1326913297, https://doi.org/10.5194/acp-15-13269-2015, 2015.

Konovalov, I. B., Beekmann, M., Berezin, E. V., Formenti, P., and Andreae, M. O.: Probing into the aging dynamics of biomass burning aerosol by using satellite measurements of aerosol optical depth and carbon monoxide, Atmos. Chem. Phys., 17, 45134537, https://doi.org/10.5194/acp-17-4513-2017, 2017.

Kourtchev, I., Ruuskanen, T., Maenhaut, W., Kulmala, M., and Claeys, M.: Observation of 2-methyltetrols and related photo-oxidation products of isoprene in boreal forest aerosols from Hyytiälä, Finland, Atmos. Chem. Phys., 5, 2761-2770, https://doi.org/10.5194/acp-5-2761-2005, 2005.

Kozlova, E. A., Manning, A. C., Kisilyakhov, Y., Seifert, T., and Heimann, M.: Seasonal, synoptic and diurnal-scale variability of biogeochemical trace gas and $\mathrm{O}_{2}$ from a $300 \mathrm{~m}$ tall tower in central Siberia, Global Biogeochem. Cy., 22, GB4020, https://doi.org/10.29/2008GB003209, 2008.

Kulmala, M., Suni, T., Lehtinen, K. E. J., Dal Maso, M., Boy, M., Reissell, A., Rannik, Ü., Aalto, P., Keronen, P., Hakola, H., Bäck, J., Hoffmann, T., Vesala, T., and Hari, P.: A new feedback mechanism linking forests, aerosols, and climate, Atmos. Chem. Phys., 4, 557-562, https://doi.org/10.5194/acp-4-557-2004, 2004.

Kulmala, M., Nieminen, T., Nikandrova, A., Lehtipalo, K., Manninen, H. E., Kajos, M. K., Kolari, P., Lauri, A., Petäjä, T., Krejci, R., Hansson, H.-C., Swietlicki, E., Lindroth, A., Christensen, T. R., Arneth, A., Hari, P., Bäck, J., Vesala, T., and Kerminen, V.M.: $\mathrm{CO}_{2}$-induced terrestrial climate feedback mechanism: From carbon sink to aerosol source and back, Suppl. B, Boreal Environ. Res., 19, 12-131, 2014.

Laborde, M., Crippa, M., Tritscher, T., Jurányi, Z., Decarlo, P. F., Temime-Roussel, B., Marchand, N., Eckhardt, S., Stohl, A., Baltensperger, U., Prévôt, A. S. H., Weingartner, E., and Gysel, M.: Black carbon physical properties and mixing state in the European megacity Paris, Atmos. Chem. Phys., 13, 5831-5856, https://doi.org/10.5194/acp-13-5831-2013, 2013.

Lack, D. A. and Cappa, C. D.: Impact of brown and clear carbon on light absorption enhancement, single scatter albedo and absorption wavelength dependence of black carbon, Atmos. Chem. Phys., 10, 4207-4220, https://doi.org/10.5194/acp10-4207-2010, 2010.

Lappalainen, H. K., Sevanto, S., Bäck, J., Ruuskanen, T. M., Kolari, P., Taipale, R., Rinne, J., Kulmala, M., and Hari, P.: Daytime concentrations of biogenic volatile organic compounds in a boreal forest canopy and their relation to environmental and biological factors, Atmos. Chem. Phys., 9, 5447-5459, https://doi.org/10.5194/acp-9-5447-2009, 2009. 
Lappalainen, H. K., Kerminen, V.-M., Petäjä, T., Kurten, T., Baklanov, A., Shvidenko, A., Bäck, J., Vihma, T., Alekseychik, P., Andreae, M. O., Arnold, S. R., Arshinov, M., Asmi, E., Belan, B., Bobylev, L., Chalov, S., Cheng, Y., Chubarova, N., de Leeuw, G., Ding, A., Dobrolyubov, S., Dubtsov, S., Dyukarev, E., Elansky, N., Eleftheriadis, K., Esau, I., Filatov, N., Flint, M., Fu, C., Glezer, O., Gliko, A., Heimann, M., Holtslag, A. A. M., Hõrrak, U., Janhunen, J., Juhola, S., Järvi, L., Järvinen, H., Kanukhina, A., Konstantinov, P., Kotlyakov, V., Kieloaho, A.-J., Komarov, A. S., Kujansuu, J., Kukkonen, I., Duplissy, E.-M., Laaksonen, A., Laurila, T., Lihavainen, H., Lisitzin, A., Mahura, A., Makshtas, A., Mareev, E., Mazon, S., Matishov, D., Melnikov, V., Mikhailov, E., Moisseev, D., Nigmatulin, R., Noe, S. M., Ojala, A., Pihlatie, M., Popovicheva, O., Pumpanen, J., Regerand, T., Repina, I., Shcherbinin, A., Shevchenko, V., Sipilä, M., Skorokhod, A., Spracklen, D. V., Su, H., Subetto, D. A., Sun, J., Terzhevik, A. Y., Timofeyev, Y., Troitskaya, Y., Tynkkynen, V.P., Kharuk, V. I., Zaytseva, N., Zhang, J., Viisanen, Y., Vesala, T., Hari, P., Hansson, H. C., Matvienko, G. G., Kasimov, N. S., Guo, H., Bondur, V., Zilitinkevich, S., and Kulmala, M.: PanEurasian Experiment (PEEX): towards a holistic understanding of the feedbacks and interactions in the land-atmosphere-oceansociety continuum in the northern Eurasian region, Atmos. Chem. Phys., 16, 14421-14461, https://doi.org/10.5194/acp-1614421-2016, 2016.

Leaitch, W. R., Macdonald, A. M., Brickell, P. C., Liggio, J., Sjosted, S., Vlasenko, A., Bottenheim, J. W., Huang, L., Li, S. M., Liu, P. S. K., Toom-Sauntry, D., Hayden, K. L., Sharma, S., Shantz, N. C., Wiebe, H., Zhang, W., Abbatt, J., Slowik, J., Chang, R. Y. W., Russell, L. M., Schwartz, R. E., Takahama, S., Jayne, J. T., and Ng, N. L.: Temperature response of the submicron organic aerosol from temperate forests, Atmos. Environ., 45, 6696-6704 https://doi.org/10.1016/j.atmosenv.2011.08.047, 2011.

Lee, S., Baumann, K., Schauer, J. J., Sheesley, R. J., Naeher, L. P., Meinardi, S., Blake, D. R., Edgerton, E. S., Russell, A. G., and Clements, M.: Gaseous and particulate emissions from prescribed burning in Georgia, Environ. Sci. Technol., 39, 90499056, https://doi.org/10.1021/es0515831, 2005.

Li, P. H., Han, B., Huo, J., Lu, B., Ding, X., Chen, L., Kong, S. F., Bai, Z. P., and Wang, B.: Characterization, meteorological influences and source identification of carbonaceous aerosol during autumn-winter period in Tianjin, China, Aerosol Air Qual. Res., 2, 283-294, https://doi.org/10.4209/aaqr.2011.09.0140, 2012.

Li, X. H., Wang, S. X., Duan, L., Hao, J. M., Li, C., Chen, Y. S., and Yang, L.: Particulate and trace gas emissions from open burning of wheat straw and corn stover in China, Environ. Sci. Technol., 41, 6052-6058, 2007.

Liao, L., Kerminen, V.-M., Boy, M., Kulmala, M., and Dal Maso, M.: Temperature influence on the natural aerosol budget over boreal forests, Atmos. Chem. Phys., 14, 8295-8308, https://doi.org/10.5194/acp-14-8295-2014, 2014.

Lim, H.-J. and Turpin, B.: Origins of primary and secondary organic aerosol in Atlanta:? Results of time-resolved measurements during the Atlanta supersite experiment, Environ. Sci. Technol., 36, 4489-4496, https://doi.org/10.1021/es020648, 2002.

Liousse, C., Penner, J. E., Chuang, C., Walton, J. J., Eddleman, H., and Cachier, H.: A global three-dimensional model study of carbonaceous aerosols, J. Geophys. Res., 101, 19411-19432, 1996.
Maenhaut, W. and Claeys, M.: Characterisation and sources of carbonaceous atmospheric aerosols: final report, Brussels, Belgian Science Policy, 92 pp., 2007.

Maenhaut, W., Raes, N., Chi, X., Cafmeyer, J., and Wang, W.: Chemical composition and mass closure for $\mathrm{PM}_{2.5}$ and $\mathrm{PM}_{10}$ aerosols at K-puszta, Hungary, in summer 2006, X-Ray Spectrom., 37, 193-197, https://doi.org/10.1002/xrs.1062, 2008.

Maenhaut, W., Nava, S., Lucarelli, F., Wang, W., Chi, X., and Kulmala, M. : Chemical composition, impact from biomass burning, and mass closure for $\mathrm{PM}_{2.5}$ and $\mathrm{PM}_{10}$ aerosols at Hyytiälä, Finland, in summer 2007, X-Ray Spectrom., 40, 168171, https://doi.org/10.1002/Xrs.1302, 2011a.

Maenhaut, W., Wang, W., and Chi, X.: Semivolatile behavior and filter sampling artifacts for dicarboxylic acids during summer campaigns at three forested sites in Europe, Boreal Environ. Res., 16, 273-287, 2011b.

Matsui, H., Kondo, Y., Moteki, N., Takegawa, N., Sahu, L. K., Zhao, Y., Fuelberg, H. E., Sessions, W. R., Diskin, G., Blake, D. R., Wisthaler, A., and Koike, M.: Seasonal variation of the transport of black carbon aerosol from the Asian continent to the Arctic during the ARCTAS aircraft campaign, J. Geophys. Res., 116, D05202, https://doi.org/10.1029/2010JD015067, 2011.

Mayol-Bracero, O. L., Guyon, P., Graham, B., Roberts, G., Andreae, M. O., Decesari, S., Facchini, M. C., Fuzzi, S., and Artaxo, P., Water-soluble organic compounds in biomass burning aerosols over Amazonia: 2. Apportionment of the chemical composition and importance of the polyacidic fraction: J. Geophys. Res., 107, 8091, https://doi.org/10.1029/2001JD000522, 2002.

Mazurek, M. A., Cofer III, W. R., and Winstead, E. L.: Carbonaceous aerosols from prescribed burning of a boreal forest, in: Global Biomass Burning: Atmospheric, Climatic, and Biospheric Implications, edited by: Levine, J. S., MIT Press, Cambridge, Mass, 209-224, 1991.

McMeeking, G. R., Kreidenweis, S. M., Baker, S., Carrico, C. M., Chow, J. C., Collett Jr., J. L., Hao, W. M., Holden, A. S., Kirchstetter, T. W., Malm, W. C., Moosmüller, H., Sullivan, A. P., and Wold, C. E.: Emissions of trace gases and aerosols during the open combustion of biomass in the laboratory, J. Geophys. Res., 114, D19210, https://doi.org/10.1029/2009JD011836, 2009.

Meng Z. Y., Jiang, X. M., Yan, P., Lin, W. L., Zhang, H. D., and Wang, Y.: Characteristics and sources of $\mathrm{PM}_{2.5}$ and carbonaceous species during winter in Taiyuan, China, Atmos. Environ., 41, 6901-6908, 2007.

Mikhailov, E. F., Vlasenko, S. S., Podgorny, I. A., Ramanathan, V., and Corrigan, C. E.: Optical properties of soot-water drop agglomerates: An experimental study, J. Geophys. Res., 111, D07209, https://doi.org/10.1029/2005JD006389, 2006.

Mikhailov, E. F., Mironova, S. Y., Makarova, M. V., Vlasenko, S. S., Ryshkevich, T. I., Panov, A. V., and Andreae, M. O.: Studying seasonal variations in carbonaceous aerosol particles in the atmosphere over Central Siberia, Izv. Atmos. Ocean. Phys., 51, 423-430, https://doi.org/10.1134/S000143381504009X, 2015a.

Mikhailov, E. F., Mironov, G. N., Pöhlker, C., Chi, X., Krüger, M. L., Shiraiwa, M., Förster, J.-D., Pöschl, U., Vlasenko, S. S., Ryshkevich, T. I., Weigand, M., Kilcoyne, A. L. D., and Andreae, M. O.: Chemical composition, microstructure, and hygroscopic properties of aerosol particles at the Zotino Tall Tower Observatory (ZOTTO), Siberia, during a summer campaign, At- 
mos. Chem. Phys., 15, 8847-8869, https://doi.org/10.5194/acp15-8847-2015, 2015b.

Morris, C. E., Conen, F., Huffman, J. A., Phillips, V., Pöschl, U., and Sands, D. C.: Bioprecipitation: a feedback cycle linking Earth history, ecosystem dynamics and land use through biological ice nucleators in the atmosphere, Glob. Change Biol., 20, 341-351, https://doi.org/10.1111/gcb.12447, 2014.

Müller, D., Mattis, I., Wandinger, U., Ansmann, A., Althausen, D., and Stohl, A.: Raman lidar observations of aged Siberian and Canadian forest fire smoke in the free troposphere over Germany in 2003: Microphysical particle characterization, J. Geophys. Res., 110, D17201, https://doi.org/10.1029/2004JD005756, 2005.

Ng, N. L., Herndon, S. C., Trimborn, A., Canagaratna, M. R. Croteau, P. L., Onasch, T. B. Sueper, D., Worsnop, D. R., Zhang, Q., Sun, Y. L., and Jayne, J. T.: An Aerosol Chemical Speciation Monitor (ACSM) for routine monitoring of the composition and mass concentrations of ambient aerosol, Aerosol Sci. Tech., 45, 770-784, https://doi.org/10.1080/02786826.2011.560211, 2011.

Noe, S. M., Hüve, K., Niinemets, Ü., and Copolovici, L.: Seasonal variation in vertical volatile compounds air concentrations within a remote hemiboreal mixed forest, Atmos. Chem. Phys., 12, 3909-3926, https://doi.org/10.5194/acp-12-3909-2012, 2012.

Ohata, S., Moteki, N., Mori, T., Koike, M., and Kondo, Y.: A key process controlling the wet removal of aerosols: new observational evidence, Scientific Reports, 6, 34113, https://doi.org/10.1038/srep34113, 2016.

Pan, X., Kanaya, Y., Wang, Z., Taketani, F., Tanimoto, H., Irie, H., Takashima, H., and Inomata, S.: Emission ratio of carbonaceous aerosols observed near crop residual burning sources in a rural area of the Yangtze River Delta Region, China, J. Geophys. Res.Atmos., 117, D22304, https://doi.org/10.1029/2012JD018357, 2012.

Panov, A. V., Heintzenberg, J. Birmili, W. Seifert, P., Chi, X., Timokhina, A. V., and Andreae, M. O.: Spatial distribution of atmospheric aerosols over the territory of Eurasia in middle and high latitudes, Geography and Natural Resources, 36, 25-30, 2015.

Paramonov, M., Aalto, P. P., Asmi, A., Prisle, N., Kerminen, V.M., Kulmala, M., and Petäjä, T.: The analysis of size-segregated cloud condensation nuclei counter (CCNC) data and its implications for cloud droplet activation, Atmos. Chem. Phys., 13, 10285-10301, https://doi.org/10.5194/acp-13-10285-2013, 2013.

Paris, J.-D., Stohl, A., Nédélec, P., Arshinov, M. Yu., Panchenko, M. V., Shmargunov, V. P., Law, K. S., Belan, B. D., and Ciais, P.: Wildfire smoke in the Siberian Arctic in summer: source characterization and plume evolution from airborne measurements, Atmos. Chem. Phys., 9, 9315-9327, https://doi.org/10.5194/acp9-9315-2009, 2009.

Pierce, J. R., Chen, K., and Adams, P. J.: Contribution of primary carbonaceous aerosol to cloud condensation nuclei: processes and uncertainties evaluated with a global aerosol microphysics model, Atmos. Chem. Phys., 7, 5447-5466, https://doi.org/10.5194/acp-7-5447-2007, 2007.

Pio, C. A., Legrand, M., Oliveira, T., Afonso, J., Santos, C., Caseiro, A., Fialho, P., Barata, F., Puxbaum, H., SanchezOchoa, A., Kasper-Giebl, A., Gelencser, A., Preunkert, S., and Schock, M.: Climatology of aerosol composition (organic versus inorganic) at nonurban sites on a west-east transect across Europe, J. Geophys. Res., 112, D23S02, https://doi.org/10.1029/2006JD008038, 2007.

Pöhlker, C., Wiedemann, K., Sinha, B., Shiraiwa, M., Gunthe, S., Smith, M., Su, H., Artaxo, P., Chen, Q., Cheng, Y., Elbert, W., Gilles, M. K., Kilcoyne, A. L. D., Moffet, R. C., Weigand, M., Martin, S. T., Pöschl, U., and Andreae, M. O., Biogenic potassium salt particles as seeds for secondary organic aerosol in the Amazon, Science, 337, 1075-1078, 2012.

Pöhlker, M. L., Pöhlker, C., Ditas, F., Klimach, T., Hrabe de Angelis, I., Araújo, A., Brito, J., Carbone, S., Cheng, Y., Chi, X., Ditz, R., Gunthe, S. S., Kesselmeier, J., Könemann, T., Lavric, J. V., Martin, S. T., Mikhailov, E., Moran-Zuloaga, D., Rose, D., Saturno, J., Su, H., Thalman, R., Walter, D., Wang, J., Wolff, S., Barbosa, H. M. J., Artaxo, P., Andreae, M. O., and Pöschl, U.: Longterm observations of cloud condensation nuclei in the Amazon rain forest - Part 1: Aerosol size distribution, hygroscopicity, and new model parametrizations for CCN prediction, Atmos. Chem. Phys., 16, 15709-15740, https://doi.org/10.5194/acp-16-157092016, 2016.

Pokhrel, R. P., Beamesderfer, E. R., Wagner, N. L., Langridge, J. M., Lack, D. A., Jayarathne, T., Stone, E. A., Stockwell, C. E., Yokelson, R. J., and Murphy, S. M.: Relative importance of black carbon, brown carbon, and absorption enhancement from clear coatings in biomass burning emissions, Atmos. Chem. Phys., 17, 5063-5078, https://doi.org/10.5194/acp-17-5063-2017, 2017.

Popovicheva, O. B., Kozlov, V. S., Engling, G., Diapouli, E., Persiantseva, N. M., Timofeev, M. A., Fan, T.-S., Saraga, D., and Eleftheriadis, K.: Small-Scale Study of Siberian Biomass Burning: I. Smoke Microstructure, Aerosol Air Qual. Res., 15, 117128, https://doi.org/10.4209/aaqr.2014.09.0206, 2015.

Pöschl, U.: Atmospheric aerosols: composition, transformation, climate and health effects, Angew. Chem. Int. Edit., 44, 7520-7540, https://doi.org/10.1002/anie.200501122, 2005.

Pöschl, U., Martin, S.T., Sinha, B., Chen, Q., Gunthe, S. S., Huffman, J. A., Borrmann, S., Farmer, D. K., Garland, R. M., Helas, G., Jimenez, J. L., King, S. M., Manzi, A., Mikhailov, E., Pauliquevis, T., Petters, M. D., Prenni, A. J., Roldin, P., Rose, D., Schneider, J., Su, H., Zorn, S. R., Artaxo, P., and Andreae, M. O.: Rainforest aerosols as biogenic nuclei of clouds and precipitation in the Amazon, Science 329, 1513-1516, https://doi.org/10.1126/science.1191056, 2010.

Pummer, B. G., Bauer, H., Bernardi, J., Bleicher, S., and Grothe, H.: Suspendable macromolecules are responsible for ice nucleation activity of birch and conifer pollen, Atmos. Chem. Phys., 12, 2541-2550, https://doi.org/10.5194/acp-12-2541-2012, 2012.

Pummer, B. G., Budke, C., Augustin-Bauditz, S., Niedermeier, D., Felgitsch, L., Kampf, C. J., Huber, R. G., Liedl, K. R., Loerting, T., Moschen, T., Schauperl, M., Tollinger, M., Morris, C. E., Wex, H., Grothe, H., Pöschl, U., Koop, T., and Fröhlich-Nowoisky, J.: Ice nucleation by watersoluble macromolecules, Atmos. Chem. Phys., 15, 4077-4091, https://doi.org/10.5194/acp-15-4077-2015, 2015.

Qi, L., Li, Q., Li, Y., and He, C.: Factors controlling black carbon distribution in the Arctic, Atmos. Chem. Phys., 17, 1037-1059, https://doi.org/10.5194/acp-17-1037-2017, 2017.

Qu, W.-J., Zhang, X.-Y., Arimato R., Wang, Y.-Q., Wang, D, Sheng, L.-F., and Fu, G.: Aerosol background at two remote CAWNET sites in western China, Sci. Total Environ., 407, 3518-3529, 2009. 
Querol, X., Alastuey, A., Ruiz, C. R., Artinano, B., Hansson, H. C., Harrison, R. M., Buringh, E., ten Brink, H. M., Lutz, M., Bruckmann, P., Straehl, P., and Schneider, J.: Speciation and origin of $\mathrm{PM}_{10}$ and $\mathrm{PM}_{2.5}$ in selected European cities, Atmos. Environ., 38, 6547-6555, 2004.

Reisinger, P., Wonaschutz, A., Hitzenberger, R., Petzold, A., Bauer, H., Jankowski, N., Puxbaum, H., Chi, X., and Maenhaut, W.: Intercomparison of measurement techniques for black or elemental carbon under urban background conditions in wintertime: influence of biomass combustion, Environ. Sci. Technol., 42, 884889, https://doi.org/10.1021/es0715041, 2008.

Rosenfeld, D., Fromm, M., Trentmann, J., Luderer, G., Andreae, M. O., and Servranckx, R.: The Chisholm firestorm: observed microstructure, precipitation and lightning activity of a pyro-cumulonimbus, Atmos. Chem. Phys., 7, 645-659, https://doi.org/10.5194/acp-7-645-2007, 2007.

Rosenfeld, D., Wood, R., Donner, L., and Sherwood, S.: Aerosol cloud-mediated radiative forcing: highly uncertain and opposite effects from shallow and deep clouds, in: Climate science for serving society, edited by: Asrar, G. R. and Hurrell, J. W., Springer, the Netherlands, 105-149, 2013.

Ruckstuhl, A. F., Henne, S., Reimann, S., Steinbacher, M., Vollmer, M. K., O'Doherty, S., Buchmann, B., and Hueglin, C.: Robust extraction of baseline signal of atmospheric trace species using local regression, Atmos. Meas. Tech., 5, 2613-2624, https://doi.org/10.5194/amt-5-2613-2012, 2012.

Saarikoski, S., Timonen, H., Saarnio, K., Aurela, M., Järvi, L., Keronen, P., Kerminen, V.-M., and Hillamo, R.: Sources of organic carbon in fine particulate matter in northern European urban air, Atmos. Chem. Phys., 8, 6281-6295, https://doi.org/10.5194/acp-8-6281-2008, 2008.

Saarnio, K., Aurela, M., Timonen, H., Saarikoski, S., Teinilä, K., Mäkelä, T., Sofiev, M., Koskinen, J., Aalto, P. P., Kulmala, M., Kukkonen, J., and Hillamo, R.: Chemical composition of fine particles in fresh smoke plumes from boreal wildland fires in Europe, Sci. Total Environ., 408, 2527-2542, https://doi.org/10.1016/j.scitotenv.2010.03.010, 2010.

Sakamoto, K. M., Laing, J. R., Stevens, R. G., Jaffe, D. A., and Pierce, J. R.: The evolution of biomass-burning aerosol size distributions due to coagulation: dependence on fire and meteorological details and parameterization, Atmos. Chem. Phys., 16, 7709-7724, https://doi.org/10.5194/acp-16-7709-2016, 2016.

Saleh, R., Robinson, E. S., Tkacik, D. S., Ahern, A. T., Liu, S., Aiken, A. C., Sullivan, R. C., Presto, A. A., Dubey, M. K., Yokelson, R. J., Donahue, N. M., and Robinson, A. L.: Brownness of organics in aerosols from biomass burning linked to their black carbon content, Nat. Geosci., 7, 647-650, https://doi.org/10.1038/ngeo2220, 2014.

Saxena, P., Hildemann, L. M., McMurry, P. H., and Seinfeld, J. H.: Organics alter hygroscopic behavior of atmospheric particles, J. Geophys. Res., 100D, 18755-18770, 1995.

Schnaiter, M., Linke, C., Möhler, O., Naumann, K. H., Saathoff, H., Wagner, R., Schurath, U., and Wehner, B.: Absorption amplification of black carbon internally mixed with secondary organic aerosol, J. Geophys. Res.-Atmos., 110, D19204, https://doi.org/10.1029/2005jd006046, 2005.

Shiraiwa, M., Kondo, Y., Iwamoto, T., and Kita, K.: Amplification of light absorption of black carbon by organic coating, Aerosol Sci. Tech., 44, 46-54, https://doi.org/10.1080/02786820903357686, 2010.

Shvidenko, A., Nilsson, S., Dixon, R., and Rojkov, V.: Burning biomass in the territories of the former Soviet Union: impact on the carbon budget, Idorjaras, Quarterly Journal of the Hungarian Meteorological Service, 99, 235-255, 1995.

Shvidenko, A., Schepaschenko, D., Vaganov, E. A., Sukhinin, A. I., Maksyutov, Sh., McCallum, I., and Lakyda, I. P.: Impacts of wildfire in Russia between 1998-2010 on ecosystems and the global carbon budget, Proc. Russian Academy of Sciences, Dokl. Earth Sci., 441, 1678-1682, 2011.

Singh, A., Rastogi, N., Patel, A., Satish, R. V., and Singh, D.: Size-segregated characteristics of carbonaceous aerosols over the northwestern Indo-Gangetic Plain: year round temporal behavior, Aerosol Air Qual. Res., 16, 1615-1624, https://doi.org/10.4209/aaqr.2016.01.0023, 2016.

Smolyakov, B. S., Makarov, V. I., Shinkorenko, M. P., Popova, S. A., Bizin, M. A.: Effects of Siberian wildfires on the chemical composition and acidity of atmospheric aerosols of remote urban, rural and background territories, Environ. Pollut., 188, 8-16, https://doi.org/10.1016/j.envpol.2014.01.017, 2014.

Spackman, J. R., Schwarz, J. P., Gao, R. S., Watts, L. A., Thomson, D. S., Fahey, D. W., Holloway, J. S., de Gouw, J. A., Trainer, M., and Ryerson, T. B.: Empirical correlations between black carbon aerosol and carbon monoxide in the lower and middle troposphere, Geophys. Res. Lett., 35, L19816, https://doi.org/10.1029/2008GL035237, 2008.

Spracklen, D. V. and Rap, A.: Natural aerosol-climate feedbacks suppressed by anthropogenic aerosol, Geophys. Res. Lett., 40, 5316-5319, https://doi.org/10.1002/2013GL057966, 2013.

Stein, A. F., Draxler, R. R, Rolph, G. D., Stunder, B. J. B., Cohen, M. D., and Ngan, F.: NOAA's HYSPLIT atmospheric transport and dispersion modeling system, B. Am. Meteorol. Soc., 96, 2059-2077, https://doi.org/10.1175/BAMS-D-14 $00110.1,2015$.

Steiner, A. L., Brooks, S. D., Deng, C., Thornton, D. C. O., Pendleton, M. W., and Bryant, V.: Pollen as atmospheric cloud condensation nuclei, Geophys. Res. Lett., 42, 3596-3602, https://doi.org/10.1002/2015GL064060, 2015.

Stohl, A., Klimont, Z., Eckhardt, S., Kupiainen, K., Shevchenko, V. P., Kopeikin, V. M., and Novigatsky, A. N.: Black carbon in the Arctic: the underestimated role of gas flaring and residential combustion emissions, Atmos. Chem. Phys., 13, 8833-8855, https://doi.org/10.5194/acp-13-8833-2013, 2013.

Timonen, H., Saarikoski, S., Tolonen-Kivimäki, O., Aurela, M., Saarnio, K., Petäjä, T., Aalto, P. P., Kulmala, M., Pakkanen, T., and Hillamo, R.: Size distributions, sources and source areas of water-soluble organic carbon in urban background air, Atmos. Chem. Phys., 8, 5635-5647, https://doi.org/10.5194/acp-8-56352008, 2008.

Trentmann, J., Luderer, G., Winterrath, T., Fromm, M. D., Servranckx, R., Textor, C., Herzog, M., Graf, H.-F., and Andreae, M. O.: Modeling of biomass smoke injection into the lower stratosphere by a large forest fire (Part I): reference simulation, Atmos. Chem. Phys., 6, 5247-5260, https://doi.org/10.5194/acp6-5247-2006, 2006.

Tunved, P., Hansson, H. C., Kerminen, V. M., Strom, J., Dal Maso, M., Lihavainen, H., Viisanen, Y., Aalto, P. P., Komppula, M., and 
Kulmala, M.: High natural aerosol loading over boreal forests, Science, 312, 261-263, 2006.

Turpin, B. J. and Lim, H.-J.: Species contributions to $\mathrm{PM}_{2.5}$ mass moncentrations: Revisiting common assumptions for estimating organic mass, Aerosol Sci. Tech., 35, 602-610, 2001.

Turpin, B. J., Saxena, P., and Andrews, E.: Measuring and simulating particulate organics in the atmosphere: problems and prospects, Atmos. Environ., 34, 2983-3013, 2000.

Van Dingenen, R., Raes, F., Putaud, J. P., Baltensperger, U., Charron, A., Facchini, M. C., Decesari, S., Fuzzi, S., Gehrig, R., Hansson, H. C., Harrison, R. M., Huglin, C., Jones, A. M., Laj, P., Lorbeer, G., Maenhaut, W., Palmgren, F., Querol, X., Rodriguez, S., Schneider, J., ten Brink, H., Tunved, P., Torseth, K., Wehner, B., Weingartner, E., Wiedensohler, A., and Wahlin, P.: A European aerosol phenomenology-1: physical characteristics of particulate matter at kerbside, urban, rural and background sites in Europe, Atmos. Environ., 38, 2561-2577, https://doi.org/10.1016/j.atmosenv.2004.01.040, 2004.

Vasileva, A. V., Moiseenko, K. B., Mayer, J. C., Jurgens, N., Panov, A., Heimann, M., and Andreae, M. O.: Assessment of the regional atmospheric impact of wildfire emissions based on CO observations at the ZOTTO tall tower station in central Siberia, J. Geophys. Res., 116, D07301, https://doi.org/10.1029/2010JD014571, 2011.

Verma, R. L., Sahu, L. K., Kondo, Y., Takegawa, N., Han, S., Jung, J. S., Kim, Y. J., Fan, S., Sugimoto, N., Shammaa, M. H., Zhang, Y. H., and Zhao, Y.: Temporal variations of black carbon in Guangzhou, China, in summer 2006, Atmos. Chem. Phys., 10, 6471-6485, https://doi.org/10.5194/acp-10-6471-2010, 2010.

Verma, R. L., Kondo, Y., Oshima, N., Matsui, H., Kita, K., Sahu, L. K., Kato, S., Kajii, Y., Takami, A., and Miyakawa, T.: Seasonal variations of the transport of black carbon and carbon monoxide from the Asian continent to the western Pacific in the boundary layer, J. Geophys. Res., 116, D21307, https://doi.org/10.1029/2011JD015830, 2011.

Vestenius, M., Hellén, H., Levula, J., Kuronen, P., Helminen, K. J., Nieminen, T., Kulmala, M., and Hakola, H.: Acidic reaction products of monoterpenes and sesquiterpenes in atmospheric fine particles in a boreal forest, Atmos. Chem. Phys., 14, 7883-7893, https://doi.org/10.5194/acp-14-7883-2014, 2014.

Wang, Y. X., Wang, X., Kondo, Y., Kajino, M., Munger, J. W., and Hao, J. M.: Black carbon and its correlation with trace gases at a rural site in Beijing: Top-down constraints from ambient measurements on bottom-up emissions, J. Geophys. Res., 116, D24304, https://doi.org/10.1029/2011JD016575, 2011.

Warneke, C., Bahreini, R., Brioude, J., Brock, C. A., de Gouw, J.A., Fahey, D. W., Froyd, K. D., Holloway, J. S., Middlebrook, A., Miller, L., Montzka, S., Murphy, D. M., Peischl, J., Ryerson, T. B., Schwarz, J. P., Spackman, J. R., and Veres, P: Biomass burning in Siberia and Kazakhstan as an important source for haze over the Alaskan Arctic in April 2008, Geophys. Res. Lett., 36, L02813, https://doi.org/10.1029/2008GL036194, 2009.
Wegener, A.: Thermodynamik der Atmosphäre, Leipzig, 331 pp., 1911.

Witkowska, A., Lewandowska, A., and Falkowska, L. M.: Parallel measurements of organic and elemental carbon dry $\left(\mathrm{PM}_{1}, \mathrm{PM}_{2.5}\right)$ and wet (rain, snow, mixed) deposition into the Baltic Sea, Mar. Pollut. Bull., 104, 302-312, https://doi.org/10.1016/j.marpolbul.2016.01.003, 2016.

Wu, C., Huang, X. H. H., Ng, W. M., Griffith, S. M., and $\mathrm{Yu}$, J. Z.: Inter-comparison of NIOSH and IMPROVE protocols for OC and EC determination: implications for interprotocol data conversion, Atmos. Meas. Tech., 9, 4547-4560, https://doi.org/10.5194/amt-9-4547-2016, 2016.

Yan, B., Zheng, M., Hu, Y. T., Lee, S., Kim, H. K., and Russell, A. G.: Organic composition of carbonaceous aerosols in an aged prescribed fire plume, Atmos. Chem. Phys., 8, 6381-6394, https://doi.org/10.5194/acp-8-6381-2008, 2008.

Zhao, Z., Cao, J., Shen, Z., Huang, R.-J., Hu, T., Wang, P., Zhang, T., and Liu, S.: Chemical composition of $\mathrm{PM}_{2.5}$ at a high-altitude regional background site over Northeast of Tibet Plateau, Atmos. Pollut. Sci., 6, 815-823, 2015.

Zhang, F., Zhou, L. X., Novelli, P. C., Worthy, D. E. J., Zellweger, C., Klausen, J., Ernst, M., Steinbacher, M., Cai, Y. X., Xu, L., Fang, S. X., and Yao, B.: Evaluation of in situ measurements of atmospheric carbon monoxide at Mount Waliguan, China, Atmos. Chem. Phys., 11, 5195-5206, https://doi.org/10.5194/acp11-5195-2011, 2011.

Zhang, Q., Jimenez, J. L., Canagaratna, M. R., et al.: Ubiquity and dominance of oxygenated species in organic aerosols in anthropogenically-influenced Northern Hemisphere midlatitudes, Geophys. Res. Lett., 34, L13801, https://doi.org/10.1029/2007GL029979, 2007.

Zhang, R., Khalizov, A. F., Pagels, J., Zhang, D., Xue, H., and McMurry, P. H.: Variability in morphology, hygroscopicity, and optical properties of soot aerosols during atmospheric processing, P. Natl. Acad. Sci. USA, 105, 10291-10296, https://doi.org/10.1073/pnas.0804860105, 2008.

Zhang, T., Wooster, M. J., Green, D. C., and Main, B.: New fieldbased agricultural biomass burning trace gas, $\mathrm{PM}_{2.5}$, and black carbon emission ratios and factors measured in situ at crop residue fires in Eastern China, Atmos. Environ., 121, 22-34, https://doi.org/10.1016/j.atmosenv.2015.05.010, 2015.

Zhang, Y., Obrist, D., Zielinska, B., and Gertler, A.: Particulate emissions from different types of biomass burning, Atmos. Environ., 72, 27-35, 2013. 